\title{
8. LATE EOCENE TO HOLOCENE DIATOM BIOSTRATIGRAPHY OF THE EQUATORIAL PACIFIC OCEAN, DEEP SEA DRILLING PROJECT LEG 851
}

\author{
John A. Barron, U.S. Geological Survey, Menlo Park²
}

\begin{abstract}
Excellent reference sections for lower Oligocene through Holocene diatoms were recovered at DSDP Sites 572 to 575 in the central equatorial Pacific. Diatoms are generally common and well preserved at all sites, except in the upper Oligocene. These sections are zoned and correlated on the basis of diatoms, including the identification and correlation of 89 additional secondary datum levels in the Miocene and Pliocene. Paleomagnetic stratigraphy was obtained for the entire Denticulopsis nicobarica Zone (17.8 to $16.4 \mathrm{Ma}$ ) at Site 575, and upper lower Miocene diatom datum levels are correlated directly to paleomagnetic stratigraphy for the first time.

Quantitative diatom studies of upper lower Miocene to uppermost Miocene (18.0 to 6.2 Ma) of Sites 572, 574, and 575 are supplemented by quantitative diatom studies at Sites 77 and 158 to form transects across the central and eastern equatorial Pacific. Where the sampling interval is 100,000 yr. or less, quantitative trends in Cestodiscus pulchellus, Coscinodiscus radiatus, Denticulopsis hustedtii, D. nicobarica, and Thalassiothrix longissima are readily correlatable, thereby greatly enhancing biostratigraphic resolution. Comparison of species abundance reveals minor differences between the eastern and central equatorial Pacific. Thalassionema nitzschioides, $D$. hustedtii, and $D$. nicobarica show preferences for the eastern equatorial Pacific, whereas C. pulchellus, Actinocyclus ellipticus, Coscinodiscus tuberculatus, and Nitzschia spp. seem to prefer the central equatorial Pacific.

Five new diatom taxa are proposed: Actinocyclus ellipticus var. spiralis Barron, n. var., Coscinodiscus lewisianus var. rhomboides Barron, n. var., C. loeblichii Barron, n. sp., C. yabei var. ellipticus Barron, n. var., and Thalassiosira tappanae Barron, $\mathrm{n}$. sp.
\end{abstract}

\section{INTRODUCTION}

The central equatorial Pacific has been a key area for biostratigraphic and paleoceanographic studies since the inception of the Deep Sea Drilling Project. Drilling has been carried out on four previous DSDP legs in the region (Legs 5, 8, 9, and 16), and nearly all major studies of Oligocene to Quaternary tropical microfossils and isotopes in the Pacific have utilized cores collected from the area. The section at DSDP Site 77 alone has figured in more such studies than any other Pacific DSDP section. The main purpose of Leg 85 was to revisit the central equatorial Pacific with the hydraulic piston corer (HPC) to recover a series of upper Eocene through Quaternary reference sections that are relatively free of the drilling disturbance associated with rotary coring. The HPC allows coring in the upper 100 to $300 \mathrm{~m}$ of sediment, making possible the collection of relatively undisturbed material having high sediment accumulation rates $(15 \mathrm{~m} /$ m.y.), which is crucial to high-resolution stratigraphic and paleoceanographic studies. The five Leg 85 sites selected by the JOIDES Ocean Paleoenvironment Panel form transects from the eastern equatorial Pacific (Sites 571 and 572) to the central equatorial Pacific (Sites 573 to 575) and from south to north across equatorial highproductivity zones of the Oligocene to Holocene (Sites 573 to 575 ) (Fig. 1).

Diatoms are present throughout all five sections cored on Leg 85 (Sites 571 to 575). Only one core of the uppermost Quaternary Pseudoeunotia doliolus Zone was re-

\footnotetext{
${ }^{1}$ Mayer, L., Theyer, F., et al., Init. Repts. DSDP, 85: Washington (U.S. Govt. Printing Office).

2 Address: U.S. Geological Survey, 345 Middlefield Road, Menlo Park, CA 94025.
}

covered at Site 571 , but drilling at Sites 572 to 575 produced numerous cores with uppermost Eocene to Quaternary diatoms. Coring at Sites 572 and 575 terminated in the lower middle Miocene (about $15 \mathrm{Ma}$ ) and lower Miocene (about $22 \mathrm{Ma}$ ), respectively. Uppermost Eocene to Quaternary sections were cored at both Site 573 and Site 574. Diatom preservation was poor in the upper Oligocene, and most of the lower Miocene of Site 573 is barren of diatoms; otherwise, diatom preservation was typically good to excellent.

Previous studies of Oligocene to Quaternary diatom biostratigraphy in the area have been numerous. R. Kolbe (1954) pioneered diatom biostratigraphic work in the tropics with his study of piston cores collected by the Swedish Deep Sea Expedition. V. V. Mukhina and A. P. Jousé have led Russian diatomists in a major effort to document late Cenozoic equatorial diatom assemblages (Mukhina, 1963, 1965, 1966, 1969; Jousé, 1968, 1973, 1977). L. H. Burckle calibrated numerous late early Miocene to Quaternary diatom datum levels directly to paleomagnetic stratigraphy in piston cores collected from the area (Burckle, 1972, 1977, 1978; Burckle and Opdyke, 1977; Burckle and Trainer, 1979; Burckle et al., 1982; Opdyke et al., 1974). Deep Sea Drilling Project studies have included those of Milow (in Hays et al., 1972, Leg 9), Bukry (1973, Leg 17), Gombos (1975, DSDP Site 66), Barron (1981a, 1983), Barron and Burckle (in Keller et al., 1982, DSDP Site 77), and Harwood (1982, Oligocene to lower Miocene of DSDP Sites 65 and 77). Other studies within the easternmost equatorial Pacific have also been helpful in refining late Cenozoic diatom biostratigraphy in the area: Bukry and Foster (1973, Leg 16), Barron (1980a, Leg 54), Harper et al. (1982, Leg 67), and Sancetta (1982, 1983, Legs 68 and 69). 


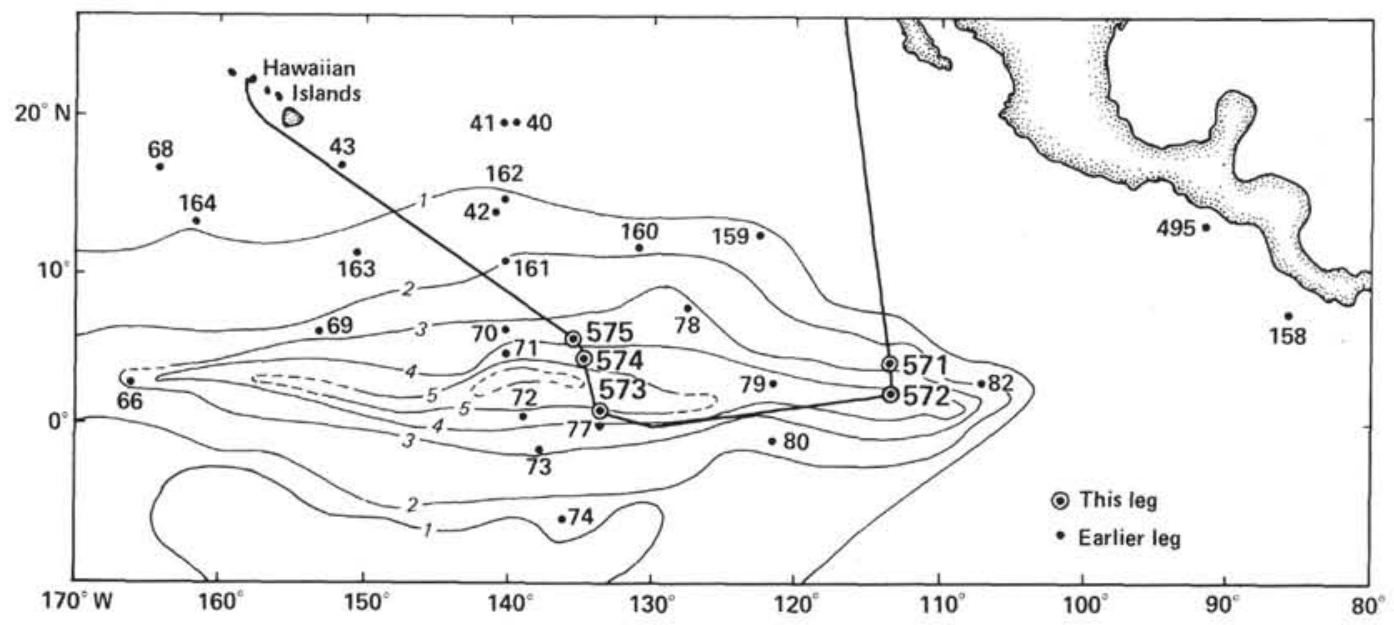

Figure 1. Locations of Leg 85 sites and other DSDP sites studied in the central and eastern equatorial Pacific. Contours represent two-way traveltime in tenths of seconds.

Leg 85 offers the opportunity to apply the knowledge gained from these and other studies of the low-latitude Atlantic Ocean (Fenner, in press) and Indian Ocean (Schrader, 1974) to develop an updated and refined late Cenozoic diatom biostratigraphy for the central equatorial $\mathrm{Pa}$ cific. In addition, graphic correlation techniques and quantitative diatom biostratigraphy (Barron and Keller, 1983) might also be applied to refine late Cenozoic time to 100,000 yrs. or less, so that the gap between conventional biostratigraphy and high-resolution isotope and $\mathrm{CaCO}_{3}$ stratigraphy could be bridged. Such high-resolution biostratigraphy is necessary for integrated paleoceanographic and paleoclimatic studies, and for understanding the nature and mechanisms of oceanic and climatic change.

\section{METHODS}

Typically, two to three samples per 9.5 -m core were selected for study; in selected intervals, one sample per $1.5-\mathrm{m}$ section was examined. Samples ( 3 to $5 \mathrm{~cm}^{3}$ ) were treated with $10 \%$ hydrochloric acid to remove the calcium carbonate. Core-catcher samples, which were processed on ship, were then cleansed of acid by centrifuging at $2000 \mathrm{rpm}$ for 2 min., decanting off the liquid, washing in distilled water, and repeating that cycle four or more times. Care was taken in selecting corecatcher samples from a single lithology in order to minimize possible contamination. Samples processed on shore were cleansed by washing in distilled water in a $250-\mathrm{ml}$ beaker, settling for $2 \mathrm{hrs}$., and decanting the liquid away. Generally, four such cycles were necessary to remove the acid. Strewn slides were prepared by sampling the suspended sample with a pipette, spreading it on a $22 \mathrm{~mm} \times 30 \mathrm{~mm}$ cover glass, drying on a hot plate, and mounting in Hyrax.

The entire microscope slide was scanned at $500 \times$ to check for the presence of biostratigraphic marker species. These marker species were selected from Burckle (1978), Fenner (in press), and the author's own studies (Barron, 1980a, b; 1981a, b; 1983; in press). Identifications of species were checked routinely at $1250 \times$.

Quantitative studies were done at $1250 \times$, using random traverses across the slide and counting the first 300 diatoms encountered. The counting techniques of Schrader and Gersonde (1978) were used, and resting spores were not counted.

The paleomagnetic time scale of Berggren et al. (in press) has been adopted for Leg 85 studies, and absolute ages obtained by first- and second-order calibrations to paleomagnetics reflect that time scale. The time scale adopted for Leg 85 utilizes Berggren et al.'s (in press) age estimates for the paleomagnetic anomalies, but it is based on the traditional Anomaly 5-Chron 9 correlation (Barron et al., this volume).

\section{ZONATION}

The diatom zonation used here (Table 1) is that proposed by Barron (in press) for the Miocene through Quaternary of the equatorial Pacific, and a modification of that of Fenner (in press) for the Oligocene. Barron's (in press) zonation consists of Burckle's (1972) upper Miocene through Quaternary zonation, Barron's (1983) lower

Table 1. Diatom zonation with defining marker taxa used for Leg 85 studies.

\begin{tabular}{|c|c|c|}
\hline Zone & Subzone & Marker $^{\mathrm{a}}$ \\
\hline \multicolumn{2}{|l|}{ P. doliolus } & \multirow{32}{*}{$\begin{array}{l}\text { T. Nitzschia reinholdii } \\
\text { T. Rhizosolenia praebergonii var. robusta } \\
\text { B. Pseudoeunotia doliolus } \\
\text { T. Thalassiosira convexa } \\
\text { T. Nitzschia jouseae } \\
\text { B. Rhizosolenia praebergonii } \\
\text { B. Nitzschia jouseae } \\
\text { T. Thalassiosira miocenica } \\
\text { T. Thalassiosira praeconvexa } \\
\text { B. Thalassiosira convexa } \\
\text { B. Thalassiosira praeconvexa } \\
\text { B. Nitzschia miocenica } \\
\text { T. Thalassiosira burckliana } \\
\text { T. Coscinodiscus yabei (plicatus) } \\
\text { B. Thalassiosira burckliana } \\
\text { T. Actinocyclus moronensis } \\
\text { T. Craspedodiscus coscinodiscus } \\
\text { B. Coscinodiscus temperei var. delicata } \\
\text { T. Coscinodiscus lewisianus } \\
\text { T. Cestodiscus peplum } \\
\text { T. Annellus californicus } \\
\text { B. Cestodiscus peplum } \\
\text { T. Thalassiosira bukryi } \\
\text { B. Denticulopsis nicobarica } \\
\text { T. Craspedodiscus elegans } \\
\text { T. Bogorovia veniamini } \\
\text { T. Coscinodiscus oligocenicus } \\
\text { T. Thalassiosira primalabiata } \\
\text { B. Rossiella paleacea } \\
\text { B. Rocella gelida } \\
\text { B. Bogorovia veniamini } \\
\text { T. Cestodiscus mukhinae } \\
\text { T. Coscinodiscus excavatus } \\
\text { B. Coscinodiscus excavatus } \\
\text { a }\end{array}$} \\
\hline \multirow{4}{*}{$\begin{array}{l}\begin{array}{l}\text { Nitzschia } \\
\text { reinholdii }\end{array} \\
\begin{array}{c}\text { Rhizosolenia } \\
\text { praebergonii }\end{array}\end{array}$} & B & \\
\hline & $\mathrm{A}$ & \\
\hline & $\mathrm{C}$ & \\
\hline & B & \\
\hline \multicolumn{2}{|c|}{ Nitzschia jouseae } & \\
\hline \multirow{3}{*}{$\begin{array}{l}\text { Thalassiosira } \\
\text { convexa }\end{array}$} & C & \\
\hline & $\bar{B}$ & \\
\hline & A & \\
\hline \multirow{2}{*}{$\begin{array}{l}\text { Nitzschia } \\
\quad \text { miocenica }\end{array}$} & B & \\
\hline & A & \\
\hline \multirow{4}{*}{$\begin{array}{l}\text { Nitzschia } \\
\text { porteri } \\
\text { Coscinodiscus } \\
\text { yabei } \\
\end{array}$} & B & \\
\hline & A & \\
\hline & B & \\
\hline & A & \\
\hline \multicolumn{2}{|c|}{ Actinocyclus moronensis } & \\
\hline \multirow{3}{*}{\multicolumn{2}{|c|}{$\begin{array}{l}\text { Craspedodiscus coscinodiscus } \\
\text { Coscinodiscus gigas var. diorama } \\
\text { Coscinodiscus lewisianus }\end{array}$}} & \\
\hline & & \\
\hline & & \\
\hline Cestodiscus & B & \\
\hline peplum & $\mathrm{A}$ & \\
\hline \multirow{2}{*}{$\begin{array}{l}\text { Denticulopsis } \\
\text { nicobarica }\end{array}$} & B & \\
\hline & A & \\
\hline \multicolumn{2}{|c|}{ Triceratium pileus } & \\
\hline \multicolumn{2}{|c|}{ Craspedodiscus elegans } & \\
\hline \multirow{2}{*}{$\begin{array}{l}\text { Rossiella } \\
\quad \text { paleacea }\end{array}$} & $\mathrm{C}$ & \\
\hline & B & \\
\hline \multirow{2}{*}{\multicolumn{2}{|c|}{ Rocella gelida }} & \\
\hline Bogorovia veniamini & & \\
\hline \multirow{2}{*}{$\begin{array}{l}\text { Rocella } \\
\quad \text { vigilans }\end{array}$} & $\bar{B}$ & \\
\hline & $\mathrm{A}$ & \\
\hline \multicolumn{2}{|c|}{ Coscinodiscus excavatus } & \\
\hline
\end{tabular}

${ }^{\text {a }}$. = first occurrence (bottom); T. = last occurrence (top). 
Miocene zonation, and new middle Miocene zones to bridge the gap between the two zonations.

Assignment of Leg 85 samples to this zonation is summarized on Table 2. All zonal and subzonal assignments were made using primary marker taxa. The zones themselves, their subzones and contained datum levels, and their correlation with other planktonic microfossil zones and with diatom zones are discussed thoroughly in the following section. Correlation of the various diatom zonations is shown on Figures 2 and 3. Table 3 shows the stratigraphic positions of 89 secondary upper Cenozoic diatom datum levels that occur in two or more of the Leg 85 sections. Absolute ages have been obtained for these datum levels both by direct correlation with paleomagnetic stratigraphy and by extrapolation between the paleomagnetically calibrated datum levels in age-versusdepth plots for the four main Leg 85 sections. These methods will be discussed more thoroughly in a later section of this chapter.

\section{Upper Eocene?}

Sections 1 and 2 of Core 574C-34 contain Cestodiscus robustus Jousé, C. mukhinae Jousé, C. pulchellus sensu Jousé (1973), Coscinodiscus decrescens Grunow, C. oligocenicus Jousé, Melosira architecturalis Brun, and Hemiaulus polycystinorum Ehrenberg; but the sections lack Coscinodiscus excavatus Greville. According to the argument that follows, these sections are tentatively assigned to the upper Eocene, an assignment supported by data on calcareous nannofossils and benthic foraminifers. Study of planktonic foraminifers indicates assignment of these sections to the lower Oligocene (P18) (see site chapter).

\section{Coscinodiscus excavatus Zone}

Category: Taxon-range zone

Author: Fenner (1984), modified here.

Definition: Interval of the total range of Coscinodiscus excavatus.

Age: Early Oligocene, about 36.5 to $33 \mathrm{Ma}$ (extrapolated, Barron et al., this volume).

Remarks: Jousé (1973) and Fenner (1977) recognized the stratigraphic utility of $C$. excavatus in the tropical $\mathrm{Pa}$ cific and subtropical South Atlantic respectively. This zonal definition is in contrast to that of Fenner (1984), who proposed the $C$. excavatus Zone as the interval between the first occurrence of $C$. excavatus and the first occurrence of Cestodiscus reticulatus Fenner, at DSDP Site 366 in the tropical Atlantic. She proposed the Cestodiscus reticulatus Zone for the overlying interval containing the total range of $C$. reticulatus, noting that the last occurrence of Coscinodiscus excavatus was near the top of that zone at DSDP Site 369. C. excavatus is a large, easily recognizable diatom, whereas Cestodiscus reticulatus can be easily confused with Cestodiscus robustus Jousé. For purposes of this preliminary report, these two Cestodiscus species were not separated, so the Coscinodiscus excavatus Range Zone has been utilized here without recognition of Fenner's (1984) C. reticulatus Zone.
Characteristic flora: Cestodiscus robustus (including $C$. reticulatus) is the most common constituent of the $C$. excavatus Zone floras; Coscinodiscus excavatus, $C$. oligocenicus, and C. sp. cf. C. marginatus Ehrenberg are the next most common species. Other characteristic species include Cestodiscus mukhinae and C. pulchellus sensu Jousé (1973). Melosira architecturalis Brun, Coscinodiscus spiralis Hajos, and Hemiaulus polycystinorum var. mesolepta Grunow are sporadic, being more characteristic of the lower part of the zone.

Correlation: Fenner (1984) places the first occurrence of Coscinodiscus excavatus within the upper part of the Eocene DSDP Core 366-10. This placement lies just above the CP16/CP15 calcareous nannofossil zonal boundary of Bukry (1978a) and just below the P17/ P18 boundary of G. Keller (pers. comm., 1983) at Site 366 . As such, this diatom datum very nearly coincides with the Eocene/Oligocene boundary of Berggren et al. (in press), which is the boundary used in the Leg 85 time scale. At Sites 573 and 574, the base of the $C$. excavatus Zone lies at or just above the CP16/CP15 zonal boundary, so it appears that the first occurrence of $C$. excavatus is isochronous between the tropical Atlantic and tropical Pacific.

At Site 369, Fenner (in press) places the last occurrence of $C$. excavatus, which defines the top of the C. excavatus Zone, near the base of CP17, within the Globigerina ampliaperta Zone (= P19-P20), and near the top of the Thyrsocyrtis tuberosa Zone of radiolarians. In Leg 85 material, the last $C$. excavatus in Samples 573B-34,CC and 574C-27,CC is correlative with the top of the T. tuberosa Zone but is slightly above the top of CP17. C. excavatus is sparse near its last occurrence, and its last occurrence in Leg 85 material was determined with sieved slides. Admittedly, such a procedure is not preferable for diatom biostratigraphy, and other biostratigraphic criteria, such as Fenner's (in press) last occurrence of Cestodiscus reticulatus, may, with further study, be a better zonal marker to use within this interval of the Oligocene.

Correlation with other diatom zones: As stated in the foregoing, the $C$. excavatus Zone is equivalent to the C. excavatus and the Cestodiscus reticulatus zones of Fenner (1984). It is also correlative with Jousé's (1973) Cestodiscus pulchellus Zone and at least part of her C. mukhinae Zone, and with the uppermost Rylandsia inequiradiata to lower Rhizosolenia gravida Zone of Gombos and Ciesielski (1983) (Fig. 2).

Rouxia hannae Jousé is restricted to Subzone b of the Cestodiscus reticulatus Zone of Fenner (in press) and to the lower $R$. gravida Zone of Gombos and Ciesielski (1983). Although $R$. hannae was not observed in Leg 85 sediments, Fenner's (in press) correlation of its range with upper planktonic foraminiferal Zone P20 has been used to suggest correlation with the upper $C$. excavatus Zone of this chapter.

\section{Rocella vigilans Zone}

Category: Interval zone.

Author: Fenner (1984), modified here. 
Table 2. Assignment of Leg 85 samples to the diatom zonation.

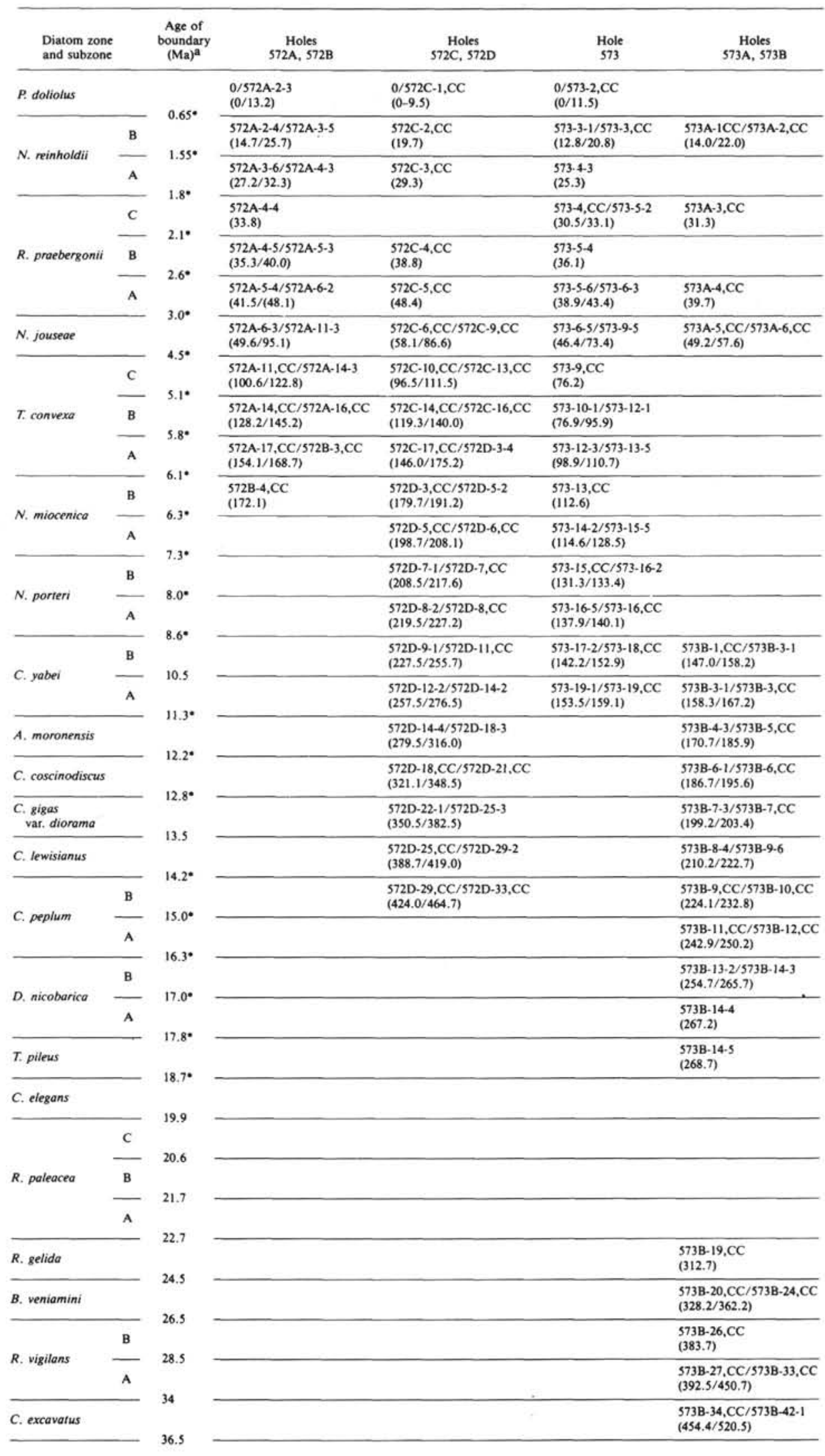

Note: Uppermost and lowermost section numbers assigned to each zone/subzone are separated by a slash. Numbers in parentheses are sub-bottom depths of these sections in meters. All zonal/subzonal assignments are based on primary markers.

a Asterisk indicates direct paleomagnetic calibration (see text). 
Table 2. (Continued).

\begin{tabular}{|c|c|c|c|}
\hline $\begin{array}{l}\text { Hole } \\
574\end{array}$ & $\begin{array}{c}\text { Holes } \\
\text { 574A, 574B, 574C }\end{array}$ & $\begin{array}{c}\text { Holes } \\
575,575 \mathrm{~A}\end{array}$ & $\begin{array}{c}\text { Holes } \\
\text { 575B, 575C }\end{array}$ \\
\hline $\begin{array}{l}0 / 574-1, \mathrm{CC} \\
(0 / 4.5)\end{array}$ & & $\begin{array}{l}575-1-1 \\
(0.5)\end{array}$ & \\
\hline $\begin{array}{l}574-2-2 \\
(7.3)\end{array}$ & & $\begin{array}{l}575-1-3 \\
(3.5)\end{array}$ & \\
\hline \multirow[t]{2}{*}{$\begin{array}{l}574-2-3 / 574-2-4 \\
(8.3 / 9.4)\end{array}$} & & & \\
\hline & & $\begin{array}{l}575-1-4 \\
(5.0)\end{array}$ & \\
\hline $\begin{array}{l}574-2, \mathrm{CC} \\
(14.1)\end{array}$ & $\begin{array}{l}574 \mathrm{~A}-2, \mathrm{CC} \\
(15.4)\end{array}$ & $\begin{array}{l}575-1-5 \\
(6.5)\end{array}$ & $\begin{array}{l}575 C-1, C C \\
(6.3)\end{array}$ \\
\hline $\begin{array}{l}574-3-2 / 574-4-4 \\
(16.8 / 29.3)\end{array}$ & $\begin{array}{l}574 \mathrm{~A}-3, \mathrm{CC} \\
(23.9)\end{array}$ & $\begin{array}{l}575-1, \mathrm{CC} \\
(7.3)\end{array}$ & $\begin{array}{l}575 \mathrm{~B}-1, \mathrm{CC} \\
(12.8)\end{array}$ \\
\hline $\begin{array}{l}574-4, \mathrm{CC} \\
(33.1)\end{array}$ & $\begin{array}{l}574-4, \mathrm{CC} \\
(33.1)\end{array}$ & & \\
\hline $\begin{array}{l}574-5-2 / 574-5, \mathrm{CC} \\
(34.9 / 42.5)\end{array}$ & $\begin{array}{l}574 \mathrm{~A}-5, \mathrm{CC} \\
(42.3)\end{array}$ & $\begin{array}{l}575-2-1 / 575-2-3 \\
(7.8 / 10.8)\end{array}$ & \\
\hline $\begin{array}{l}574-6-2 \\
(44.4)\end{array}$ & & $\begin{array}{l}575-2-4 \\
(12.3)\end{array}$ & \\
\hline $\begin{array}{l}574-6-4 / 574-6-6 \\
(47.4 / 50.4)\end{array}$ & & $\begin{array}{l}575-2-5 \\
(13.8)\end{array}$ & \\
\hline $\begin{array}{l}574-6, C C / 574-7-2 \\
(52.0 / 53.9)\end{array}$ & $\begin{array}{l}574 \mathrm{~A}-6, \mathrm{CC} \\
(51.9)\end{array}$ & $\begin{array}{l}575-2-6 / 575-3-2 \\
(15.3 / 18.8)\end{array}$ & $\begin{array}{l}575 \mathrm{~B}-2, \mathrm{CC} \\
(21.5)\end{array}$ \\
\hline $\begin{array}{l}574-7-4 / 574-7, \mathrm{CC} \\
(56.9 / 60.9)\end{array}$ & & $\begin{array}{l}575-3-3 / 575-3-5 \\
(20.3 / 23.3)\end{array}$ & $\begin{array}{l}575 \mathrm{~B}-3-4 / 575 \mathrm{~B}-3, \mathrm{CC} \\
(24.2 / 29.7)\end{array}$ \\
\hline $\begin{array}{l}574-8-1 \\
(61.4)\end{array}$ & $\begin{array}{l}574 \mathrm{~A}-7, \mathrm{CC} \\
(61.3)\end{array}$ & & \\
\hline $\begin{array}{l}574-8-3 / 574-8-7 \\
(64.4 / 70.1)\end{array}$ & $\begin{array}{l}574 \mathrm{~A}-8, \mathrm{CC} \\
(70.4)\end{array}$ & $\begin{array}{l}575-3-6 / 575-3, \mathrm{CC} \\
(24.8 / 26.3)\end{array}$ & \\
\hline $\begin{array}{l}574-8, C C / 574-9-6 \\
(70.5 / 78.4)\end{array}$ & & $\begin{array}{l}575-4-1 \\
(26.8)\end{array}$ & \\
\hline $\begin{array}{l}574-9, \mathrm{CC} / 574-11-4 \\
(80.0 / 94.4)\end{array}$ & $\begin{array}{l}574 \mathrm{~A}-9, \mathrm{CC} / 574 \mathrm{~A}-10, \mathrm{CC} \\
(79.9 / 87.2)\end{array}$ & $\begin{array}{l}575-4-2 / 575-4-5 \\
(28.3 / 32.8)\end{array}$ & $\begin{array}{l}575 B-4, C C \\
(39.1)\end{array}$ \\
\hline $\begin{array}{l}574-11, C C / 574-13-2 \\
(98,6 / 110.0)\end{array}$ & $\begin{array}{l}574 \mathrm{~A}-11, \mathrm{CC} / 574 \mathrm{~A}-12, \mathrm{CC} \\
(98.8 / 108.2)\end{array}$ & $\begin{array}{l}575-4-6 / 575-5-4 \\
(34.3 / 39.9) \\
\end{array}$ & $\begin{array}{l}575 \mathrm{~B}-5, C \mathrm{CC} \\
(48.3)\end{array}$ \\
\hline $\begin{array}{l}574-13-4 / 574-16-2 \\
(113.0 / 129.5)\end{array}$ & $\begin{array}{l}574 \mathrm{~A}-13, \mathrm{CC} / 574 \mathrm{~A}-16, \mathrm{CC} \\
(113.1 / 127.1)\end{array}$ & $\begin{array}{l}575-5, C C / 575-6-4 \\
(44.6 / 49.4)\end{array}$ & $\begin{array}{l}575 \mathrm{~B}-6, \mathrm{CC} \\
(55.9)\end{array}$ \\
\hline $\begin{array}{l}574-16, \mathrm{CC} / 574-20, \mathrm{CC} \\
(132.6 / 152.5)\end{array}$ & $\begin{array}{l}574 \mathrm{~A}-17, \mathrm{CC} / 574 \mathrm{~A}-19, \mathrm{CC} \\
(132.7 / 150.9)\end{array}$ & $\begin{array}{l}575-6, C C / 575-8-2 \\
(54.0 / 65.4)\end{array}$ & \\
\hline $\begin{array}{l}574-21-2 / 574-24, \mathrm{CC} \\
(154,4 / 172.5)\end{array}$ & $\begin{array}{l}574 \mathrm{~A}-20, \mathrm{CC} / 574 \mathrm{~A} \cdot 21, \mathrm{CC} \\
(160.2 / 167.4)\end{array}$ & $\begin{array}{l}575-8, C C / 575-9-2 \\
(73.0 / 74.9)\end{array}$ & $\begin{array}{l}575 \mathrm{~B}-11-1 / 575 \mathrm{~B}-11-3 \\
(79.4 / 82.4)\end{array}$ \\
\hline $\begin{array}{l}574-25-2 / 574-29-2 \\
(174.4 / 194.2)\end{array}$ & $\begin{array}{l}574 \mathrm{~A}-22, \mathrm{CC} / 574 \mathrm{~B}-1, \mathrm{CC} \\
(178.0 / 194.4)\end{array}$ & $\begin{array}{l}575-9, \mathrm{CC} / 575 \mathrm{~A}-1-1 \\
(74.9 / 94.3)\end{array}$ & $\begin{array}{l}575 \mathrm{~B}-11-4 / 575 \mathrm{~B}-13-1 \\
(83.9 / 96.4)\end{array}$ \\
\hline \multirow[t]{13}{*}{$\begin{array}{l}574-29, \mathrm{CC} / 574-31, \mathrm{CC} \\
(197.2 / 206.5)\end{array}$} & $\begin{array}{l}574 \mathrm{C}-1, \mathrm{CC} / 574 \mathrm{C}-2, \mathrm{CC} \\
(202.2 / 213,4)\end{array}$ & $\begin{array}{l}575 \mathrm{~A}-1-2 / 575 \mathrm{~A}-4-1 \\
(95.8 / 105.6)\end{array}$ & $\begin{array}{l}575 B-13-2 / 575 B-14-3 \\
(97.9 / 98.4)\end{array}$ \\
\hline & $\begin{array}{l}574 C-3, C C / 574 C-4-2 \\
(218.8 / 224.9)\end{array}$ & $\begin{array}{l}575 \mathrm{~A}-4-2 / 575 \mathrm{~A}-7, \mathrm{CC} \\
(107.1 / 123.3)\end{array}$ & \\
\hline & $\begin{array}{l}574 C-4, C C / 574 C-5-3 \\
(226.7 / 235.9)\end{array}$ & $\begin{array}{l}575 \mathrm{~A}-8-1 / 575 \mathrm{~A}-12-2 \\
(123.5 / 137.0)\end{array}$ & \\
\hline & $\begin{array}{l}574 \mathrm{C}-5, \mathrm{CC} / 574 \mathrm{C}-8-1 \\
(238.8 / 261.4)\end{array}$ & $\begin{array}{l}\text { 575A-12,CC/575A-20-2 } \\
(139.6 / 162.7)\end{array}$ & \\
\hline & $\begin{array}{l}574 C-8-3 / 574 C-9, C C \\
(264.4 / 275.3)\end{array}$ & $\begin{array}{l}575 \mathrm{~A}-20, \mathrm{CC} / 575 \mathrm{~A}-24-2 \\
(164.7 / 176.1)\end{array}$ & \\
\hline & $\begin{array}{l}574 C-10-2 / 574 C-12, C C \\
(281.9 / 308.4)\end{array}$ & $\begin{array}{l}\text { 575A-24,CC/575A-30-2 } \\
(179.2 / 196.0)\end{array}$ & \\
\hline & $\begin{array}{l}574 \mathrm{C}-13-2 / 574 \mathrm{C}-15, \mathrm{CC} \\
(310.4 / 336.8)\end{array}$ & $\begin{array}{l}\text { 575A-30,CC/575A-33,CC } \\
(197.9 / 208.3)\end{array}$ & \\
\hline & $\begin{array}{l}574 C-16-1 / 574 C-17, C C \\
(337.4 / 354.0)\end{array}$ & & \\
\hline & $\begin{array}{l}574 C-18-1 / 574 C-19, C C \\
(356.4 / 368.2)\end{array}$ & & \\
\hline & $\begin{array}{l}574 C-20, C C / 574 C-21, C C \\
(384.2 / 390.6)\end{array}$ & & \\
\hline & $\begin{array}{l}574 C-22, C C / 574 C-26, C C \\
(398.9 / 435.9)\end{array}$ & & \\
\hline & $\begin{array}{l}574 C-27, C C / 574 C-33, C C \\
(446.9 / 506.0)\end{array}$ & & \\
\hline & $574 C-34-1 / 574 C-34-2$ & & \\
\hline
\end{tabular}




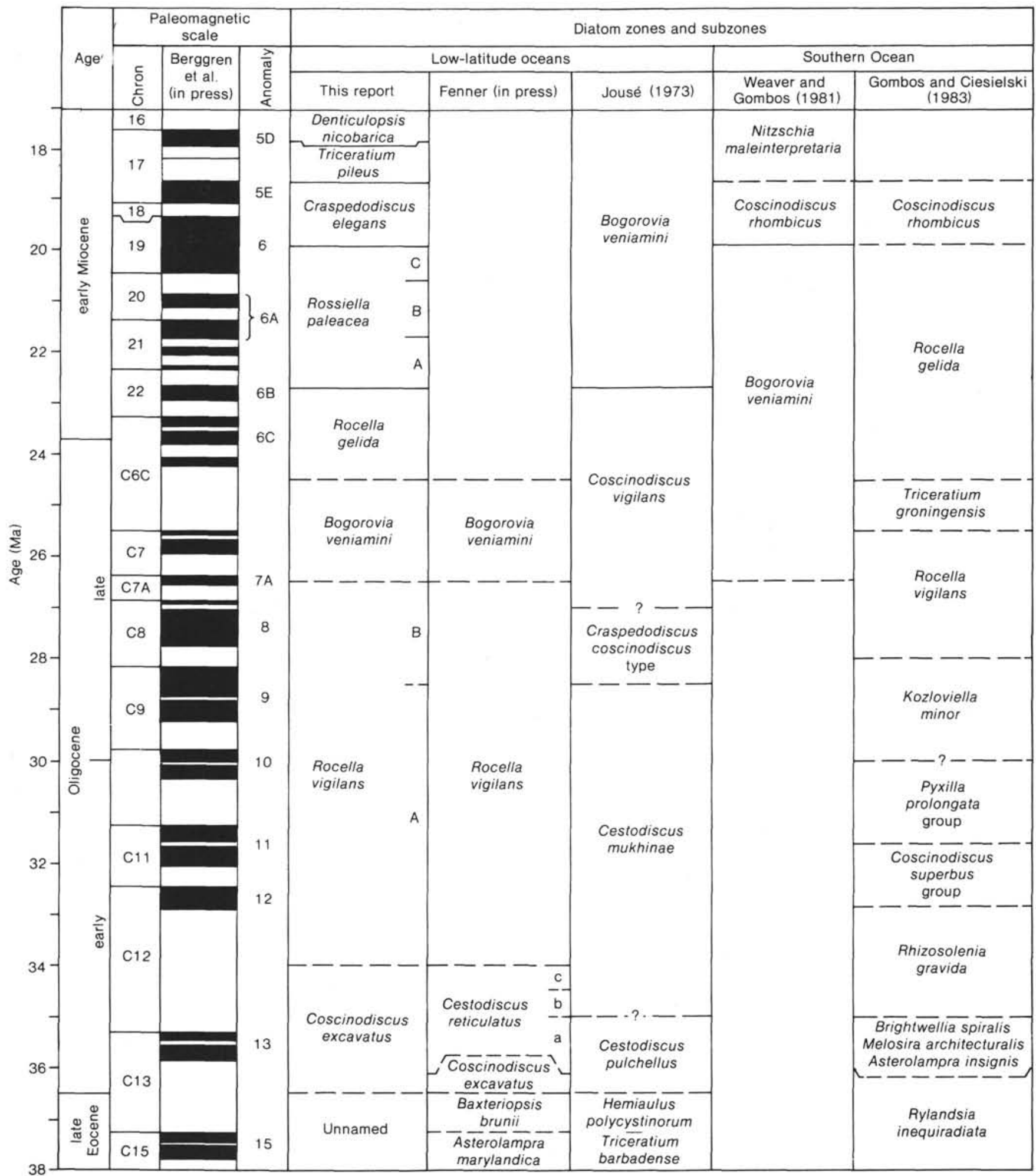

Figure 2. Correlation of the low-latitude diatom zonation of this report (Barron, 1983 and this report; Fenner, 1984) with the low-latitude diatom zonations of Fenner (in press) and Jousé (1973) and the Southern Ocean diatom zonations of Weaver and Gombos (1981) and Gombos and Ciesielski (1983) for the latest Eocene to middle early Miocene. Correlations are after Barron (1983) and this report.

Definition: Interval between the last occurrence of Coscinodiscus excavatus and the first occurrence of $\mathrm{BO}$ gorovia veniamini.

Subzones: Two subzones are proposed: Subzone A, from the base of the zone to the last occurrence of Cesto- discus mukhinae, and Subzone B, from the top of Subzone A to the top of the zone.

Age: Early to late Oligocene, about 33 to about $26.5 \mathrm{Ma}$. Subzone A/Subzone B boundary, about 28.5 Ma. (Ages extrapolated, Barron et al., this volume.) 


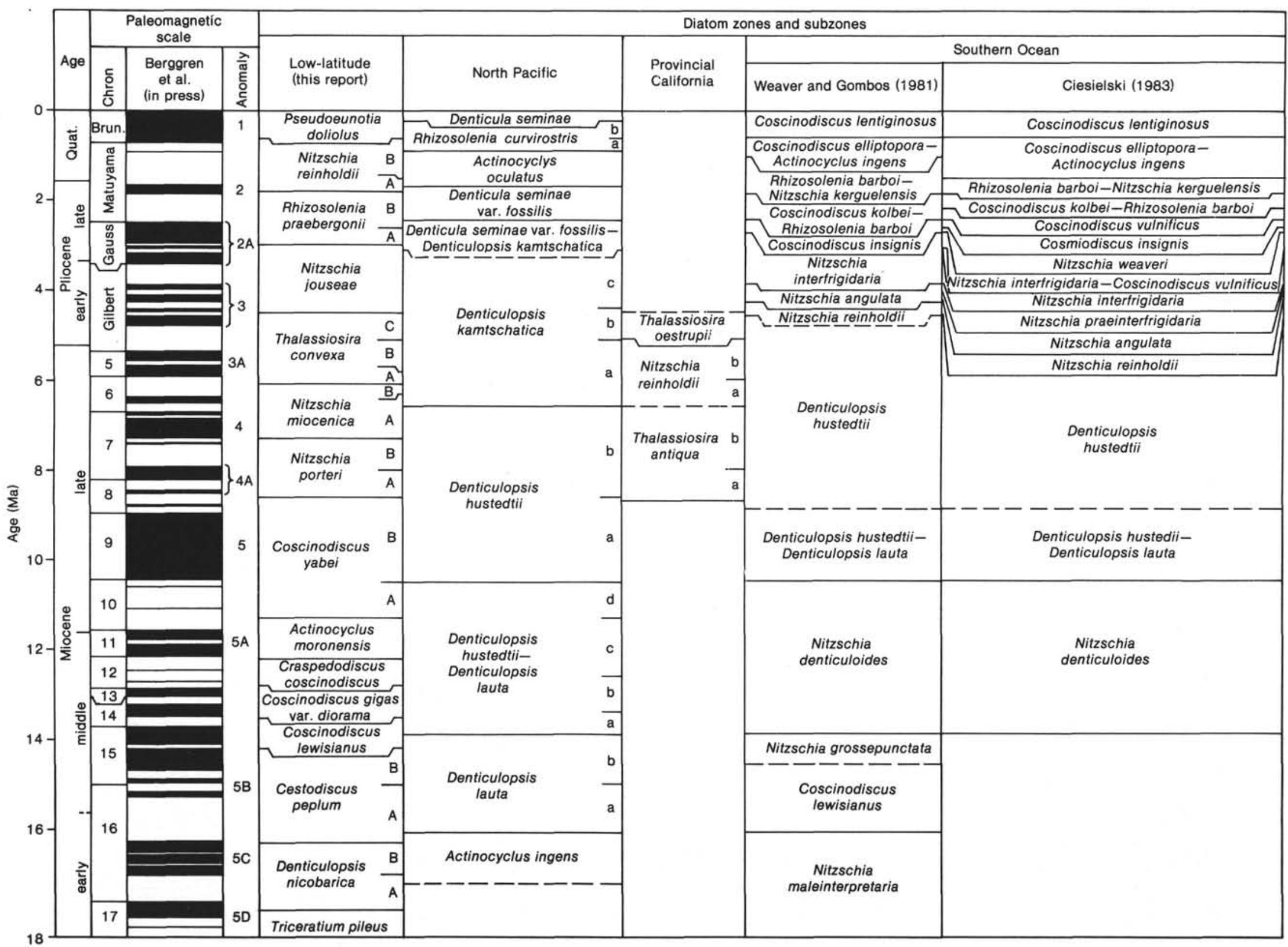

Figure 3. Correlation of the low-latitude diatom zonation of this report (Burckle, 1972; Barron, in press and 1983) with the North Pacific diatom zonation (Koizumi, 1973; Barron, 1980a; Barron and Keller, 1983), the provincial California diatom zonation for the latest Miocene to earliest Pliocene (Barron, 1981a), and the Southern Ocean diatom zonations of Weaver and Gombos (1981) and Ciesielski (1983) for the latest early Miocene through the Quaternary. Correlations are after Barron (in press), Ciesielski (1983), and this report. 
Table 3. Correlation of secondary late Cenozoic diatom datum levels between Sites 572, 573, 574, and 575. Samples (HoleCore-Section, level in $\mathrm{cm}$ ) that constrain each datum level are separated by a slash.

\begin{tabular}{|c|c|c|c|c|c|}
\hline Datum & $\begin{array}{c}\mathrm{Age} \\
(\mathrm{Ma})^{\mathrm{a}}\end{array}$ & Site 572 & Site 573 & Site 574 & Site 575 \\
\hline T. Rhizosolenia matuyamai & $0.93(1)$ & $572 A-2-5 / 572 A-2-6$ & & & \\
\hline B. Rhizosolenia matuyamai & 1.0 (1) & $572 \mathrm{~A}-2-6 / 572 \mathrm{~A}-2, \mathrm{CC}$ & & & \\
\hline I. Rhizosolenia praebergonii & $1.82(2)$ & $572 \mathrm{~A}-4-3 / 572 \mathrm{~A}-4-4$ & $573-4-3 / 573-4, C C$ & $574-1, \mathrm{CC} / 574-2, \mathrm{CC}$ & $575-1-3 / 575-1-4$ \\
\hline T. Actinocyclus ellipticus f. lanceolata & $3.5-3.2$ & $572 A-7-1 / 572 A-7 \cdot 2$ & $573-6-5 / 573-6, \mathrm{CC}$ & $574-3-2 / 574-3-4$ & $575-1, C C / 575-2-1$ \\
\hline B. Thalassiosira convexa var. convexa & $3.6(2)$ & $572 \mathrm{~A}-7 \cdot 2 / 572 \mathrm{~A} \cdot 7-3$ & $573-7-1 / 573-7-3$ & $574-3-4 / 574-3, C C$ & $575-1, C C / 575-2-1$ \\
\hline B. Asteromphalus elegans & $\begin{array}{ll}3.9 & (3) \\
4.3 & (3)\end{array}$ & $572 A-7-5 / 572 A-7-6$ & $573-8-1 / 573-8-5$ & & $\begin{array}{l}575-1, C C / 575-2-1 \\
575-1, C C / 575-2-1\end{array}$ \\
\hline $\begin{array}{l}\text { T. Nitzschia cylindrica } \\
\text { B. Thalassiosira oesirupii }\end{array}$ & $\begin{array}{ll}4.3 & (3) \\
5.1 & (3)\end{array}$ & $\begin{array}{l}572 \mathrm{~A}-9, \mathrm{CC} / 572 \mathrm{~A}-10-3 \\
572 \mathrm{~A}-13, \mathrm{CC} / 572 \mathrm{~A}-14, \mathrm{CC}\end{array}$ & $\begin{array}{l}573-8-5 / 573-8, C C \\
573-9, C C / 573-10-1\end{array}$ & $\begin{array}{l}574-4.4 / 574-4, C C \\
574-4, C C / 574-5-2\end{array}$ & $\begin{array}{l}575-1, C C / 575-2-1 \\
575-1, C C / 575-2-1\end{array}$ \\
\hline $\begin{array}{l}\text { D. Asterolampra acutiloba } \\
\text { T. }\end{array}$ & 5.35 (3) & $572 \mathrm{~A} \cdot 14, \mathrm{CC} / 572 \mathrm{~A}-15-3$ & $573-10-1 / 573-10, C \mathrm{C}$ & $574-5-5 / 574-5, C C$ & $575-2-3 / 575-2-4$ \\
\hline T. Nitzschia miocenica & 5.55 (3) & $572 \mathrm{~A}-15, \mathrm{CC} / 572 \mathrm{~A}-16-3$ & $573-11-5 / 573-11, \mathrm{CC}$ & $574-5-5 / 574-5, \mathrm{CC}$ & $575-2-3 / 575-2-4$ \\
\hline T. Nitzschia miocenica var. elongata & 5.65 (4) & $572 \mathrm{~A}-16-3 / 572 \mathrm{~A}-16, \mathrm{CC}$ & $573-11, \mathrm{CC} / 573-12-1$ & $574-5, \mathrm{CC} / 574-6-2$ & $575-2-3 / 575-2-4$ \\
\hline T. Rassiella praepaleacea & 6.0 (4) & $572 \mathrm{D}-2, \mathrm{CC} / 572 \mathrm{D}-3, \mathrm{CC}$ & $573-12, \mathrm{CC} / 573-13-2$ & $574-6-2 / 574-6-4$ & $575-2-5 / 575-2-6$ \\
\hline B. Thalassiosira miocenica & 6.1 (3) & $572 \mathrm{D}-3-4 / 572 \mathrm{D}-3, \mathrm{CC}$ & $573-13-5 / 573-13, \mathrm{CC}$ & $574-6-2 / 574-6-4$ & $575-2-4 / 575-2-5$ \\
\hline T. Nirzschia porteri & & $572 \mathrm{D}-5, \mathrm{CC} / 572 \mathrm{D}-6-1$ & $573-14, \mathrm{CC} / 573-15-4$ & $574-6, \mathrm{CC} / 574.7 .2$ & $575-3-2 / 575-3-3$ \\
\hline T. Rossiella paleacea & $7.4(3)$ & $572 \mathrm{D}-6, \mathrm{CC} / 572 \mathrm{D}-7-1$ & $573-15-5 / 573-15, \mathrm{CC}$ & $574-7-2 / 574-7-4$ & $575 \cdot 3 \cdot 2 / 575 \cdot 3-3$ \\
\hline T. Coscinodiscus nodulifer var. cyclopus & 7.9 & $572 \mathrm{D}-7-5 / 572 \mathrm{D}-7, \mathrm{CC}$ & $573-16-2 / 573-16-5$ & $574-7-2 / 574-7-4$ & $575-3-3 / 575-3-4$ \\
\hline B. Nitzschia reinholdii s. ampl. & 8.0 & $572 \mathrm{D}-7, \mathrm{CC} / 572 \mathrm{D}-8.2$ & $573-16-2 / 573-16-5$ & $574-7.4 / 574-7-6$ & $575-3 \cdot 4 / 575-3-5$ \\
\hline T. Actinocyclus ellipticus var. javanicus & 8.0 & $572 \mathrm{D}-7, \mathrm{CC} / 572 \mathrm{D}-8-2$ & $573-16-2 / 573-16-5$ & $574-7-4 / 574-7-6$ & $575 \cdot 3-4 / 575 \cdot 3-5$ \\
\hline B. Nitzschia marina & $8.2-8.1$ & $572 \mathrm{D}-8-2 / 572 \mathrm{D}-8-4$ & $573-16-5 / 573-16, \mathrm{CC}$ & $574-7, \mathrm{CC} / 574-8-1$ & $575-3-5 / 575-3-6$ \\
\hline B. Nitzschia cylindrica s, ampl. & $8.7-8.6$ & $572 \mathrm{D}-9-1 / 572 \mathrm{D}-9-3$ & $573-17-2 / 573-17-5$ & $574-7, \mathrm{CC} / 574-8.1$ & $575-3, \mathrm{CC} / 575-4-1$ \\
\hline B. Coscinodiscus nodulifer var, cyclopus & $8.9-8.8$ & $572 \mathrm{D}-9-3 / 572 \mathrm{D}-9, \mathrm{CC}$ & $573-17-2 / 573-17-5$ & $574-8-3 / 574-8-5$ & $575-3-6 / 575-3, C C$ \\
\hline T. Coscinodiscus yabei vat, ellipticus & $9.5-9.4$ & $572 \mathrm{D}-10-2 / 572 \mathrm{D}-10-4$ & $573-17, C C / 573-18-3$ & $574-8-3 / 574-8-5$ & \\
\hline T. Coscinodiscus loeblichii & $9.5-9.4$ & $572 \mathrm{D}-10-2 / 572 \mathrm{D}-10-4$ & $573-17, \mathrm{CC} / 573-18-3$ & $574 \cdot 8 \cdot 3 / 574 \cdot 8 \cdot 5$ & $575-3, \mathrm{CC} / 575-4-1$ \\
\hline T. Coscinodiscus temperei var. delicata & 9.7 & $572 \mathrm{D}-10-6 / 572 \mathrm{D}-10, \mathrm{CC}$ & $573-18-3 / 573-18, \mathrm{CC}$ & $574-8-3 / 574-8-5$ & $575-3-6 / 575-3, C C$ \\
\hline B. Nitzschia fassilis & 9.8 & $572 \mathrm{D}-10, \mathrm{CC} / 572 \mathrm{D}-11-1$ & $\begin{array}{l}573 \mathrm{~B}-2, \mathrm{CC} / 573 \mathrm{~B}-3-1,81 \\
\text { and } \\
573-18-3 / 573-18, \mathrm{CC}\end{array}$ & $574-8-3 / 574-8-5$ & $575-3, \mathrm{CC} / 575-4-1$ \\
\hline B. Coscinodiscus yabei var. ellipticus & 9.8 & $572 \mathrm{D}-10, \mathrm{CC} / 572 \mathrm{D}-11 \cdot 1$ & $\begin{array}{l}573 \mathrm{~B}-3-1,71 / 573 \mathrm{~B}-3-1,81 \\
\text { and } \\
573-18-3 / 573-18, \mathrm{CC}\end{array}$ & $574-8-7 / 574-8, C C$ & \\
\hline B. Coscinodiscus loeblichii & $10.5-10.4$ & $572 \mathrm{D}-11, \mathrm{CC} / 572 \mathrm{D}-12-2$ & $573 \mathrm{~B}-3-1,71 / 573 \mathrm{~B}-3-1,81$ & $574-8-7 / 574-8, C C$ & $575-3, \mathrm{CC} / 575-4-1$ \\
\hline T. Denticulopsis hustedtii & $11.2-10.5$ & $572 \mathrm{D}-11, \mathrm{CC} / 572 \mathrm{D}-12-2$ & $573 \mathrm{~B}-3, \mathrm{CC} / 573 \mathrm{~B}-4-3$ & $574-8-5 / 574-8-7$ & $575-3, \mathrm{CC} / 575-4-1$ \\
\hline T. Coscinodiscus vetustissimus v, javanica & 10.7 (3) & $572 \mathrm{D} \cdot 12-2 / 572 \mathrm{D} \cdot 12 \cdot 4$ & $573 \mathrm{~B}-3 \cdot 2 / 573 \mathrm{~B}-3 \cdot 4$ & $574-8, \mathrm{CC} / 574-9.1$ & $575-3, \mathrm{CC} / 575-4-1$ \\
\hline B. Coscinodiscus vetustissimus v, javanica & 11.2 (3) & $572 \mathrm{D} \cdot 13-2 / 572 \mathrm{D}-13 \cdot 4$ & $573 \mathrm{~B}-3, \mathrm{CC} / 573 \mathrm{~B}-4-3$ & $574-9.4 / 574-9, \mathrm{CC}$ & $575-4-1 / 575-4-2$ \\
\hline B. Actinocyclus ellipticus f. lanceolata & 11.4 & $572 \mathrm{D}-14-2 / 572 \mathrm{D}-14-4$ & $573 \mathrm{~B}-3, \mathrm{CC} / 573 \mathrm{~B}-4-3$ & $574-10-1 / 574-10-2$ & $575-4.2 / 575-4.4$ \\
\hline T. Coscinodiscus tuberculatus & $12.0 \quad(5)$ & $572 \mathrm{D}-17, \mathrm{CC} / 572 \mathrm{D}-18-1$ & $573 \mathrm{~B}-4, \mathrm{CC} / 573 \mathrm{~B}-5-1$ & $574-10, \mathrm{CC} / 574-11-1$ & $575-4 \cdot 2 / 575-4-4$ \\
\hline T. Denticulopsis punctata f. hustedtii & 12.1 (5) & $572 \mathrm{D}-17, \mathrm{CC} / 572 \mathrm{D}-18-1$ & $5738-4, C C / 573 B-5-1$ & $574-11-1 / 574-11-2$ & $575-4-2 / 575-4-4$ \\
\hline T. Synedra jouseana & $12.3-12.1$ & $572 \mathrm{D}-17, \mathrm{CC} / 572 \mathrm{D}-18-1$ & $573 \mathrm{~B} \cdot 5, \mathrm{CC} / 573 \mathrm{~B} \cdot 6-1$ & $574-11-1 / 574-11-2$ & $575-4-6 / 575-4 . C C$ \\
\hline B. Rossiella paleacea var. elongata & $12.3-12.2$ & $572 \mathrm{D}-18-3 / 572 \mathrm{D}-18, \mathrm{CC}$ & $573 \mathrm{~B}-5, \mathrm{CC} / 573 \mathrm{~B}-6-1$ & $574-11 \cdot 2 / 574-11 \cdot-4$ & $575-4.4 / 575-4.5$ \\
\hline B. Thalassionema robusta & $12.3-12.3$ & $572 \mathrm{D}-18-3 / 572 \mathrm{D}-18, \mathrm{CC}$ & $573 \mathrm{~B}-5, \mathrm{CC} / 573 \mathrm{~B}-6-1$ & $574-11-4 / 574.11, \mathrm{CC}$ & $575.4 .4 / 575-4.5$ \\
\hline T. Coscinodiscus gigas var. diorama & 12.3 & $572 \mathrm{D} \cdot 19 \cdot 1 / 572 \mathrm{D} \cdot 19 \cdot 3$ & $573 \mathrm{~B}-5, \mathrm{CC} / 573 \mathrm{~B}-6-1$ & $574-11 / 4 / 574-11, C C$ & $575-4-2 / 575-4-4$ \\
\hline T. Actinocycius ellipticus var. spiralis & $12.4-12.3$ & $572 \mathrm{D}-19, \mathrm{CC} / 572 \mathrm{D}-20-1$ & $573 \mathrm{~B}-5, \mathrm{CC} / 573 \mathrm{~B}-6-1$ & $574-11-4 / 574-11, C C$ & $575 \cdot 4, \mathrm{CC} / 575-5 \cdot 2$ \\
\hline B. Hemidiscus cuneiformis & $12.5 \quad(3)$ & $572 \mathrm{D}-20-2 / 572 \mathrm{D}-20, \mathrm{CC}$ & $573 \mathrm{~B}-5, \mathrm{CC} / 573 \mathrm{~B}-6-1$ & $574-12-2 / 574-12-4$ & $575-5-2 / 575-5-4$ \\
\hline B. Rossiella praepaleacea & 12.7 & $572 \mathrm{D}-21-4 / 572 \mathrm{D} \cdot 21, \mathrm{CC}$ & $573 \mathrm{~B}-6-5 / 573 \mathrm{~B} \cdot 6, \mathrm{CC}$ & $574-12-4 / 574-12, \mathrm{CC}$ & $575-5-4 / 575-5, \mathrm{CC}$ \\
\hline T. Actinocyclus ingens & $12.8-12.5$ & $572 \mathrm{D}-21, \mathrm{CC} / 572 \mathrm{D}-22-1$ & $573 \mathrm{~B}-6-5 / 573 \mathrm{~B}-6, \mathrm{CC}$ & $574-12-2 / 574-12-4$ & $575-5-4 / 575-5, \mathrm{CC}$ \\
\hline B. Nitzschia porteri & $13.1-12.9$ & $572 \mathrm{D}-22-1 / 572 \mathrm{D}-22, \mathrm{CC}$ & $573 \mathrm{~B}-6-5 / 573 \mathrm{~B}-6, \mathrm{CC}$ & $574-14, C C / 574-15-2$ & $575-5, \mathrm{CC} / 575-6.2$ \\
\hline T. Denticulopsis nicobarica & 13.2 & $572 \mathrm{D}-23-3 / 572 \mathrm{D} \cdot 23, \mathrm{CC}$ & $573 \mathrm{~B}-7, \mathrm{CC} / 573 \mathrm{~B}-8 \cdot 4$ & $574-15-2 / 574-15, C C$ & $575-6-2 / 575-6-4$ \\
\hline T. Annellus californicus & $13.5-13.4$ & $572 \mathrm{D}-24-2 / 572 \mathrm{D} \cdot 24, \mathrm{CC}$ & $573 \mathrm{~B}-8-4 / 573 \mathrm{~B}-8, \mathrm{CC}$ & $574-15, \mathrm{CC} / 574-16-2$ & $575-6-4 / 575-6, \mathrm{CC}$ \\
\hline T. Coscinodiscus salisburyanus & $13.5-13.4$ & $572 \mathrm{D}-24, \mathrm{CC} / 572 \mathrm{D}-25-3$ & $573 \mathrm{~B}-7, \mathrm{CC} / 573 \mathrm{~B}-8-4$ & $574-16-2 / 574-16, \mathrm{CC}$ & $575.6 . \mathrm{CC} / 575-7.2$ \\
\hline B. Coscinodiscus gigas var. diorama & $13.6-13.5$ & $572 \mathrm{D}-25-3 / 572 \mathrm{D}-25, \mathrm{CC}$ & $573 \mathrm{~B}-7, \mathrm{CC} / 573 \mathrm{~B}-8-4$ & $574-17-2 / 574-17, \mathrm{CC}$ & $575.6, \mathrm{CC} / 575.7 .2$ \\
\hline T. Cestodiscus pulchellus & $13.6-13.5$ & $572 \mathrm{D}-25, \mathrm{CC} / 572 \mathrm{D}-26-3$ & $573 \mathrm{~B}-7, \mathrm{CC} / 573 \mathrm{~B}-8-4$ & $574-16-2 / 574-16, \mathrm{CC}$ & $575-6, \mathrm{CC} / 575-7-2$ \\
\hline B. Denticulopsis punctata f. hustedtii & 13.7 & $572 \mathrm{D}-25, \mathrm{CC} / 572 \mathrm{D}-26, \mathrm{CC}$ & $573 \mathrm{~B}-8, \mathrm{CC} / 573 \mathrm{~B}-9-4$ & $574-16, \mathrm{CC} / 574-17-2$ & $575 \cdot 6, \mathrm{CC} / 575-7.2$ \\
\hline B. Coscinodiscus nodulifer & 13.8 & $572 \mathrm{D}-26, \mathrm{CC} / 572 \mathrm{D}-27-3$ & $573 \mathrm{~B}-8 \cdot 4 / 573 \mathrm{~B}-8, \mathrm{CC}$ & $574-17, \mathrm{CC} / 574-18-2$ & $575 \cdot 6, \mathrm{CC} / 575-7.2$ \\
\hline T. Thalassiosira tappanae & 13.8 & $572 \mathrm{D}-26, \mathrm{CC} / 572 \mathrm{D}-27-3$ & $573 \mathrm{~B}-8-4 / 573 \mathrm{~B}-8, \mathrm{CC}$ & $574-17, \mathrm{CC} / 574-18 \cdot 2$ & $575-6, \mathrm{CC} / 575-7 \cdot 2$ \\
\hline B. Coscinodiscus plicatus & $13.9-13.8$ & $572 \mathrm{D}-26, \mathrm{CC} / 572 \mathrm{D}-27-3$ & $573 \mathrm{~B}-8-4 / 573 \mathrm{~B}-8, \mathrm{CC}$ & $574-18, C C / 574-19-2$ & $575 \cdot 7-2 / 575-7, \mathrm{CC}$ \\
\hline B. Triceratium cinnamomeum & $13.9-13.8$ & $572 \mathrm{D}-26, \mathrm{CC} / 572 \mathrm{D}-27-3$ & $573 \mathrm{~B}-8-4 / 573 \mathrm{~B}-8, \mathrm{CC}$ & $574-19-2 / 574-19, C \mathrm{CC}$ & $575-7.2 / 575-7 . \mathrm{CC}$ \\
\hline T. Cestodiscus puichellus var. maculatus & 13.9 & $?$ & $573 \mathrm{~B}-8, \mathrm{CC} / 573 \mathrm{~B}-9-4$ & $574-19-3 / 574-19, \mathrm{CC}$ & $575-7.2 / 575-7 . \mathrm{CC}$ \\
\hline B. Denticulopsis hustedtii (main) & 13.9 & $572 \mathrm{D}-27, \mathrm{CC} / 572 \mathrm{D} \cdot 28 \cdot 2$ & $573 \mathrm{~B}-8, \mathrm{CC} / 573 \mathrm{~B}-9-4$ & $574-18, \mathrm{CC} / 574-19-2$ & $575-7-2 / 575-7, \mathrm{CC}$ \\
\hline B. Coscinadiscus tuberculatus & 14.0 & $572 \mathrm{D}-28-2 / 572 \mathrm{D}-28, \mathrm{CC}$ & $573 \mathrm{~B} \cdot 8, \mathrm{CC} / 573 \mathrm{~B}-9 \cdot 4$ & $574-19, \mathrm{CC} / 574-20-2$ & $575-7-2 / 575-7 . \mathrm{CC}$ \\
\hline B. Actinocyclus ellipticus var. spiralis & $14.2-14.1$ & $572 \mathrm{D}-29-2 / 572 \mathrm{D}-29 . \mathrm{CC}$ & $573 \mathrm{~B}-9.4 / 573 \mathrm{~B}-9-6$ & $574-20-2 / 574-20, \mathrm{CC}$ & $575-8-4 / 575-8, \mathrm{CC}$ \\
\hline B. Denticulopsis hustedtii (isolated) & 14.2 & $572 \mathrm{D}-29, \mathrm{CC} / 572 \mathrm{D}-30-1$ & ? & $574.20 . \mathrm{CC} / 574-21-2$ & ? \\
\hline B. Actinocyclus ellipticus & $14.4-14.3$ & $572 \mathrm{D}-30-1 / 572 \mathrm{D}-30, \mathrm{CC}$ & $573 \mathrm{~B}-9, \mathrm{CC} / 573 \mathrm{~B}-10-2$ & $574-21, \mathrm{CC} / 574-22.2$ & $575-8, \mathrm{CC} / 575-9-2$ \\
\hline B. Coscinodiscus blysmos & 14.4 & $572 \mathrm{D}-30, \mathrm{CC} / 572 \mathrm{D} \cdot 31-2$ & $573 \mathrm{~B}-9, \mathrm{CC} / 573 \mathrm{~B}-10-2$ & $574-21, \mathrm{CC} / 574-22-2$ & $575.8, \mathrm{CC} / 575-9.2$ \\
\hline B. Thalassiosira tappanae & 14.4 & $572 \mathrm{D}-30, \mathrm{CC} / 572 \mathrm{D}-31-2$ & $573 \mathrm{~B}-9, \mathrm{CC} / 573 \mathrm{~B}-10-2$ & $574-22-2 / 574-22, \mathrm{CC}$ & $575-8, \mathrm{CC} / 575-9.2$ \\
\hline T. Coscinodiscus praenodulifer & $15.5-15.4$ & & $573 \mathrm{~B}-11, \mathrm{CC} / 573 \mathrm{~B}-12.2$ & $574-26-2 / 574-26, \mathrm{CC}$ & $575-9, \mathrm{CC} / 575-10-2$ \\
\hline B. Actinocyclus ingens & 15.5 & & $573 \mathrm{~B}-10, \mathrm{CC} / 573 \mathrm{~B}-11, \mathrm{CC}$ & $574-26, \mathrm{CC} / 574 \cdot 27 \cdot 2$ & $575-10-2 / 575-10, C C$ \\
\hline T. Nitzschia maleinterpretaria & 15.6 & & $573 \mathrm{~B}-11, \mathrm{CC} / 573 \mathrm{~B}-12-2$ & $574-27, \mathrm{CC} / 574-28-1$ & $575-10, \mathrm{CC} / 575-11-2$ \\
\hline T. Coscinodiscus lewisianus var. similis & 15.7 & & $573 \mathrm{~B}-12-2 / 573 \mathrm{~B}-12.4$ & $574-27, \mathrm{CC} / 574-28-1$ & $\begin{array}{l}575-10-2 / 575 \cdot 10, C C \\
\text { and }\end{array}$ \\
\hline Occurrence Denticulopsis lauta & $15.9-15.8$ & & $573 \mathrm{~B}-12-4$ & $574-28, \mathrm{CC}$ & $\begin{array}{l}575 B-12-4 / 575 B-12-5 \\
575-10 . C C\end{array}$ \\
\hline T. Denticulopsis ef. kanayae & 16.0 & & $573 \mathrm{~B}-12-4 / 573 \mathrm{~B}-12 . \mathrm{CC}$ & $574-28, \mathrm{CC} / 574-29-2$ & $\begin{array}{l}575 \cdot 10, \mathrm{CC} \\
575 \mathrm{~A} \cdot 1-2 / 575 \mathrm{~A} \cdot 1 \cdot 3\end{array}$ \\
\hline T. Thalassiosira fraga & $16.3-16.1$ & & $573 \mathrm{~B}-13-2 / 573 \mathrm{~B}-13-4$ & $574-28, \mathrm{CC} / 574-29-2$ & $\begin{array}{l}575 \mathrm{~A}-1-2 / 575 \mathrm{~A} \cdot 1-3 \\
575-11, \mathrm{CC} / 575 \mathrm{~A}-1-1\end{array}$ \\
\hline T. Synedra miocenica & $16.5(6)$ & & $573 \mathrm{~B}-13-2 / 573 \mathrm{~B}-13-4$ & $574-29 \cdot 2 / 574-29, \mathrm{CC}$ & $575 \mathrm{~A} \cdot 1 \cdot 3 / 575 \mathrm{~A} \cdot 1, \mathrm{CC}$ \\
\hline T. Raphidodiscus marylandicus & 16.7 (6) & & $5738-13-4 / 573 \mathrm{~B}-13, \mathrm{CC}$ & $574-30, C C / 574-31-2$ & $575 \mathrm{~A}-2-3 / 575 \mathrm{~A}-2-4$ \\
\hline B. Denticulopsis cf. kanayae & 16.9 (6) & & $583 \mathrm{~B}-13-4 / 573 \mathrm{~B}-13, \mathrm{CC}$ & $574 \mathrm{C}-2, \mathrm{CC} / 574 \mathrm{C}-3, \mathrm{CC}$ & 575A-2,CC/575A-3-2 \\
\hline Occurrence Craspedodiscus rydei & 16.9 (6) & & $573 \mathrm{~B}-14-1,7$ & $574 \mathrm{C}-2, \mathrm{CC}$ & $575 \mathrm{~A}-3-2$ \\
\hline B. Coscinodiscus blysmos & 17.1 (6) & & $573 \mathrm{~B}-14-1,7 / 573 \mathrm{~B}-14-1,68$ & $574 \mathrm{C}-2, \mathrm{CC} / 574 \mathrm{C}-3, \mathrm{CC}$ & $575 \mathrm{~A}-4 \cdot 2 / 575 \mathrm{~A}-4-3$ \\
\hline B. Annellus californicus & $17.3(6)$ & & $573 \mathrm{~B}-14-1,7 / 573 \mathrm{~B}-14-1,68$ & $574 \mathrm{C}-2, \mathrm{CC} / 574 \mathrm{C}-3, \mathrm{CC}$ & 575A-5-2/575A-5-3 \\
\hline B. Craspedodiscus coscinodiscus s.str. & $17.3(6)$ & & ? & ? & 575A-5-3/575A-5,CC \\
\hline T. Coscinodiscus lewisiamus var. robustus & $17.4(6)$ & & $573 \mathrm{~B}-14-1,68 / 573 \mathrm{~B}-14-3$ & $574 \mathrm{C}-2, \mathrm{CC} / 574 \mathrm{C}-3, \mathrm{CC}$ & $575 \mathrm{~A}-5, \mathrm{CC} / 575 \mathrm{~A}-6-1$ \\
\hline B. Coscinodiscus lewisianus var. simitis & $17.4(6)$ & & $573 \mathrm{~B}-14-1,68 / 573 \mathrm{~B}-14-3$ & $574 C-2, C C / 574 C-3, C C$ & $575 \mathrm{~A}-5, \mathrm{CC} / 575 \mathrm{~A}-6-1$ \\
\hline B. Cestodiscus pulchellus var, maculatus & $17,4(6)$ & & $573 \mathrm{~B}-14-1,68 / 573 \mathrm{~B}-14-3$ & $574 \mathrm{C}-2, \mathrm{CC} / 574 \mathrm{C}, 3, \mathrm{CC}$ & $575 \mathrm{~A}-5, \mathrm{CC} / 575 \mathrm{~A}-6-1$ \\
\hline T. Thalassiosira spumellaroides & 17.5 (6) & & & $574 \mathrm{C}-2, \mathrm{CC} / 574 \mathrm{C}-3, \mathrm{CC}$ & $575 \mathrm{~A}-6-2 / 575 \mathrm{~A}-6-3$. \\
\hline T. Triceratium pileus & 17.6 (6) & & & $574 \mathrm{C}-2, \mathrm{CC} / 574 \mathrm{C}-3, \mathrm{CC}$ & $575 \mathrm{~A}-6-3 / 575 \mathrm{~A}-6, \mathrm{CC}$ \\
\hline T. Thalassiosira spinosa & 17.9 (6) & & & $574 \mathrm{C}-4, \mathrm{CC} / 574 \mathrm{C}-5-1$ & $575 \mathrm{~A}-9-2 / 575 \mathrm{~A}-9, \mathrm{CC}$ \\
\hline T. Actinocyclus radionovae & $18.0 \quad(6)$ & & & $574 C-5-1 / 574 C-5-3$ & 575A-9-2/575A-9,CC \\
\hline B. Nitzschia maleinterpretaria & 18.8 & & & $574 \mathrm{C}-5, \mathrm{CC} / 574 \mathrm{C}-6-2$ & $575 \mathrm{~A}-12, \mathrm{CC} / 575 \mathrm{~A}-13-2$ \\
\hline B. Triceratium pileus & 18.8 & & & $574 \mathrm{C}-5, \mathrm{CC} / 574 \mathrm{C}-6-2$ & $575 \mathrm{~A} \cdot 12, \mathrm{CC} / 575 \mathrm{~A}-13-2$ \\
\hline T. Actinocyclus hajosiae & 19.6 & & & ? & 575A-18-2/575A-18,CC \\
\hline B. Thalassiosira fraga & 19.9 & & & $574 \mathrm{C}-8-1 / 574 \mathrm{C}-8-3$ & $575 \mathrm{~A}-20-2 / 575 \mathrm{~A}-20, \mathrm{CC}$ \\
\hline B. Coscinodiscus lewisianus var. robustus & 20.0 & & & $574 \mathrm{C}-8-3 / 574 \mathrm{C}-8, \mathrm{CC}$ & $575 \mathrm{~A}-20-2 / 575 \mathrm{~A}-20, \mathrm{CC}$ \\
\hline T. Melosira architecturalis & $20.9-20.6$ & & & $574 C-10-4 / 574 C-10, C C$ & $575 \mathrm{~A} \cdot 24 \cdot 2 / 575 \mathrm{~A}-24, \mathrm{CC}$ \\
\hline B. Actinocychus radionovae & 21.2 & & & $574 \mathrm{C}-10, \mathrm{CC} / 574 \mathrm{C}-11, \mathrm{CC}$ & $575 \mathrm{~A}-26, \mathrm{CC} / 575 \mathrm{~A}-27, \mathrm{CC}$ \\
\hline B. Actinocyclus hajosiae & $22.0-21.6$ & & & $574 \mathrm{C}-11, \mathrm{CC} / 574 \mathrm{C}-12, \mathrm{CC}$ & $575 \mathrm{~A}-31, \mathrm{CC} / 575 \mathrm{~A}-32, \mathrm{CC}$ \\
\hline
\end{tabular}

a References indicate direct paleomagnetic calibration. (1) Burckle et al. (1978); (2) Burckle and Trainer (1979); (3) Burckle (1978); (4) Burckle (pers. comm., 1978); (5) Burckle ef al. (1982); (6) Hole 575A-Barron interpretation. Ages of other datum levels from extrapolation. The paleomagnetic time scale of Berggren et al. (in press) is utilized. 
Remarks: The interval of the $R$. vigilans Zone is generally poorly preserved in Leg 85 sediments. At Site 574, the first occurrence of Rocella vigilans Fenner coincides with the base of the zone, so the zone is exactly equivalent to the $R$. vigilans Zone of Fenner (1984). Poor preservation in the basal part of the zone at Site 573, however, obscures the first occurrence of $R$. vigilans there. At both Site 573 and Site 574, the first occurrence of Synedra jouseana Sheshukova-Poretzkaya corresponds to a restricted occurrence of Kozloviella edita Jousé and $K$. minor Jousé in Samples 573B-26,CC and 574C-21, CC at the base of Subzone B. The first occurrence of Coscinodiscus rhombicus Castracane, which marks the base of Fenner's (in press) Subzone $\mathrm{C}$ of her $R$. vigilans Zone, is in Sample 574C-20,CC, immediately below the first occurrence of Bogorovia veniamini in Sample 574C$19, \mathrm{CC}$, or top of the $R$. vigilans Zone. Preservation at Site 573 is too poor to allow recognition of the first-occurrence datum of $C$. rhombicus.

Characteristic flora: Rocella vigilans is the most consistently present species throughout the $R$. vigilans Zone, as it is robust and resistant to dissolution. Cestodiscus mukhinae is fairly consistent within Subzone A, and Synedra jouseana is fairly consistent within Subzone B. Cestodiscus robustus is present sporadically in the lower part of the zone at Site 573, as are Coscinodiscus oligocenicus and Cestodiscus pulchellus sensu Jousé (1973).

Correlation: As already stated, the Coscinodiscus excavatus/Rocella vigilans zonal boundary correlates with the lowermost part of calcareous nannofossil Zone CP18 and the base of the radiolarian Dorcadospyris ateuchus Zone. The Subzone A/Subzone B boundary falls within Zone P21 and the D. ateuchus Zone, and within either CP18 or CP19 (calcareous nannofossils) (Barron et al., this volume).

The $R$. vigilans/Bogorovia veniamini zonal boundary lies within Zone P22, Zone CP19, and in the upper part of the $D$. ateuchus Zone at Sites 573 and 574; this is slightly younger than Fenner's (in press) boundary at Site 369 .

Correlation with other diatom zones: If the first occurrence of Rocella vigilans is truly coincident with the last occurrence of Coscinodiscus excavatus, the $R$. vigilans Zone is equivalent to Fenner's (1984) $R$. vigilans Zone. The $R$. vigilans Zone also correlates with the upper part of the Cestodiscus mukhinae Zone (= Subzone A), all of the Craspedodiscus coscinodiscus type Zone, and the lowermost part of the Coscinodiscus vigilans Zone of Jousé (1973) (Fig. 2). The ranges of Kozloviella minor and Synedra jouseana suggest that Subzone B of the $R$. vigilans Zone correlates with the Kozloviella minor and Rocella vigilans zones of Gombos and Ciesielski (1983). By superposition and the correlation suggested for the $C$. excavatus Zone, Subzone A of the $R$. vigilans Zone correlates with the upper Rhizosolenia gravida Zone to the middle $K$. minor Zone of Gombos and Ciesielski (1983) (Fig. 2).

\section{Bogorovia veniamini Zone}

Category: Partial-range zone

Author: Fenner (1984).

Definition: Interval from the first occurrence of Bogorovia veniamini to the first occurrence of Rocella gelida (Mann) Bukry.

Age: Late Oligocene, about 26.5 to $24.0 \mathrm{Ma}$. (Ages extrapolated, Barron et al., this volume.)

Remarks: Sediments assigned to the Bogorovia veniamini Zone at Sites 573 and 574 contain poorly preserved diatoms.

Characteristic flora: Rocella vigilans $\mathrm{s}$. ampl. is the most common species in the $B$. veniamini Zone at Site 574, followed by Synedra jouseana and $S$. jouseana $\mathrm{f}$. linearis Sheshukova-Poretzkaya. Other characteristic diatoms include Coscinodiscus rhombicus, C. oligocenicus, C. lewisianus var. rhomboides Barron, n. var., Cestodiscus pulchellus, and Melosira architecturalis.

Correlation: As stated, the $R$. vigilans $/ B$. veniamini zonal boundary falls within planktonic foraminiferal Zone $\mathrm{P} 22$, calcareous nannofossil Zone CP19, and radiolarian $D$. ateuchus Zone. The $B$. veniamini/Rocella gelida zonal boundary is well represented at Site 574, where it is placed immediately below the first occurrence of Rocella gelida in Sample 574C-17,CC. As such, the upper boundary of the $B$. veniamini Zone occurs in the uppermost parts of Zones P22 and CP19 and within the lowermost part of the Lychnocanoma elongata Zone (radiolarians).

Correlation with other diatom zones: The $B$. veniamini Zone correlates with the middle part of the Rocella vigilans Zone of Jousé (1973), the lowermost part of the Bogorovia veniamini Zone of Weaver and Gombos (1981), and the upper Rocella vigilans Zone and the Triceratium gronigensis Zone of Gombos and Ciesielski (1983) (Fig. 2).

\section{Rocella gelida Zone}

Category: Partial-range zone.

Author: Barron (1983).

Definition: Interval from the first occurrence of Rocella gelida to the first occurrence of Rossiella paleacea (Grunow) Desikachary and Maheshwari.

Secondary markers: The last occurrence of Rocella geli$d a$ is a secondary marker for the top of the zone (Barron, 1983).

Age: Latest Oligocene to earliest Miocene, 24.0 to 22.7 Ma. (Ages extrapolated, Barron et al., in press and this volume.)

Remarks: Site 574 provides a seemingly complete section of the $R$. gelida Zone, in that it contains an interval below the first occurrence of $R$. gelida var. schraderi (Bukry) Barron (Sample 574-16,CC) and above the first occurrence of $R$. gelida s. ampl. (Sample 574C-17,CC). At Site 71, this interval is removed at a hiatus (hiatus PH of Keller and Barron, 1983) (Barron, 1983). Rocella vigilans last occurs within the upper part of the $R$. gelida Zone. 
Characteristic flora: Rocella gelida, Coscinodiscus oligocenicus, and Synedra jouseana are the dominant diatoms of the $R$. gelida Zone. Other characteristic diatoms include Coscinodiscus lewisianus var. rhomboides, C. rhombicus, Craspedodiscus coscinodiscus sensu Jousé (1977) (coarse, indented form), Bogorovia veniamini, and Actinodiscus barbadensis sensu Jousé (1977).

Correlation: At Site 574, the base of the $R$. gelida Zone lies in the uppermost parts of planktonic foraminiferal Zone P22 and calcareous nannofossil Zone CP19, and within the lowermost part of the L. elongata Zone of radiolarians. The top of the $R$. gelida Zone falls within lower planktonic foraminiferal Zone N4 and the upper part of the L. elongata Zone, and it approximates the Subzone CN1a/Subzone CN1b boundary, a correlation consistent with the results of Barron (1983).

Correlation with other diatom zones: The $R$. gelida Zone correlates with the upper part of the Coscinodiscus vigilans Zone of Jousé (1973), the middle part of the Bogorovia veniamini Zone of Weaver and Gombos (1981), and the lower part of the $R$. gelida Zone of Gombos and Ciesielski (1983) (Fig. 2).

\section{Rossiella paleacea Zone}

Category: Concurrent-range zone.

Author: Barron (1983).

Definition: Interval from the first occurrence of Rossiella paleacea to the last occurrence of Bogorovia veniamini.

Subzones: The last occurrence of Thalassiosira primalabiata Gombos defines the Subzone A/Subzone B boundary. The last occurrence of Coscinodiscus oligocenicus marks the Subzone B/Subzone $\mathrm{C}$ boundary.

Secondary markers: At Site 574, the last occurrence of Rocella gelida coincides with the base of the $R$. $p a$ leacea Zone, a relationship observed by Barron (1983) at Site 71. As indicated by Barron (1983), the first occurrences of Thalassiosira fraga Schrader and Coscinodiscus lewisianus var. robustus Barron at Sites 574 and 575 closely approximate the top of the $R$. paleacea Zone (Tables 2 and 3); however, the last occurrence of Actinocyclus hajosiae Barron at Site 575 lies substantially above the top of the zone (Table 3 ).

Age: Early Miocene, 22.7 to $19.6 \mathrm{Ma}$. Subzone A/Subzone B boundary, 21.7 Ma; Subzone B/Subzone C boundary, 20.2 Ma. (Extrapolated ages, Barron et al., in press and this volume.)

Remarks: Sites 574 and 575 have good sequences of the $R$. paleacea Zone, although drilling at Site 575 was terminated in the upper part of Subzone A. Within Subzone A are the last occurrence of Coscinodiscus lewisianus var. rhomboides (Sample 574C-15,CC), near its base, and the first occurrences of Coscinodiscus praenodulifer Barron (Sample 574C-14,CC) and Thalassiosira spumellaroides Schrader (Sample 574C13,CC). Raphidodiscus marylandicus and Craspedodiscus elegans Ehrenberg are too sparse and sporadic at Site 574 to determine whether their first occurrences fall within Subzone A, as is reported by Barron (1983).

The first occurrence of Actinocyclus hajosiae is within Subzone B at Site 574 (Sample 574C-11,CC) and within Subzone A at Site 575 (Sample 575A-31,CC) (Table 3). Either that datum or the last occurrence of Thalassiosira primalabiata, the top of Subzone A, is diachronous between Sites 574 and 575. Radiolarian biostratigraphy at Site 71 (Dunn, 1982, compared with Barron, 1983), Site 574, and Site 575 (Nigrini, this volume) suggests that the first occurrence of $A$. hajosiae is isochronous, occurring in the lowermost part of the Stichocorys delmontensis Zone at all three sites. Placement of the Subzone A/Subzone B boundary at Sites 71 and 575 is consistent with these results, but placement of the boundary at Site 574 may be as much as two cores too low. With further study, it may be found that the first occurrence of Actinocyclus hajosiae is a more consistent datum level to define the Subzone A/Subzone B boundary than the last occurrence of Thalassiosira primalabiata.

Subzone B contains the last occurrence of Melosira architecturalis (20.9 to 20.6 Ma) (Table 3), which varies somewhat between Sites 574 and 575, and the first occurrence of Actinocyclus radionovae Barron (21.2 Ma).

Characteristic flora: Synedra jouseana is the most consistently common diatom of the $R$. paleacea Zone. Cestodiscus pulchellus Greville, Coscinodiscus marginatus, C. oligocenicus, C. rhombicus, and Bogorovia veniamini also become important members of the assemblages in various parts of the zone.

Correlation: The correlations of Barron (1983) are supported in general by Leg 85 results at Sites 574 and 575 . The base of the $R$. paleacea Zone falls in lower planktonic foraminiferal Zone N4 and the uppermost part of the Lychnocanoma elongata Zone of radiolarians, and approximates the $\mathrm{CN} 1 \mathrm{a} / \mathrm{CN} 1 \mathrm{~b}$ subzonal boundary of calcareous nannofossils. The top of the $R$. paleacea Zone correlates with Zone N5, upper Zone $\mathrm{CN} 1$, and middle Stichocorys delmontensis Zone at Site 574 , but near the N4/N5 boundary at Site 575 .

Correlation with other diatom zones: The $R$. paleacea Zone is equivalent to the lower part of the Bogorovia veniamini Zone of Jousé (1973), the upper part of the B. veniamini Zone of Weaver and Gombos (1981), and the upper part of the Rocella gelida Zone of Gombos and Ciesielski (1983) (Fig. 2).

\section{Craspedodiscus elegans Zone}

Category: Partial-range zone.

Author: Barron (1983).

Definition: Interval from the last occurrence of Bogorovia veniamini to the last occurrence of Craspedodiscus elegans.

Secondary markers: The first occurrences of Thalassiosira fraga (19.9 Ma) and Coscinodiscus lewisianus var. robustus $(20.0 \mathrm{Ma})$ approximate the base of the $C$. elegans Zone. At Sites 574 and 575, the first occur- 
rences of Nitzschia maleinterpretaria Schrader (18.8 Ma) and Triceratum pileus Ehrenberg (18.8 Ma) approximate the zone's top, ranges slightly younger than those reported by Barron (1983) at Sites 71 and 495.

Age: Early Miocene, 19.9 to $18.7 \mathrm{Ma}$ (extrapolated ages, Barron et al., in press and this volume).

Remarks: Site 575 has an exceptionally thick $(22 \mathrm{~m})$, well preserved section of the $C$. elegans Zone.

Characteristic flora: Thalassiosira fraga is a common diatom within the $C$. elegans Zone, although $T$. spinosa Ehrenberg dominates over $T$. fraga in the lowermost part of the zone (Barron, 1983). Synedra jouseana and Cestodiscus pulchellus are secondarily common, and Actinocyclus radionovae, Coscinodiscus rhombicus, and $C$. marginatus are also characteristic.

Correlation: As reported by Barron (1983), the C. elegans Zone correlates with upper planktonic foraminiferal Zone N5, upper calcareous nanofossil Zone $\mathrm{CN} 1$, and the upper Stichocorys delmontensis Zone (radiolarians) at Site 575. Coincidence of the top of the $C$. elegans Zone with the tops of $\mathrm{CN} 1$ and the $S$. delmontensis Zone at Site 574 suggests a possible short hiatus there at about $237 \mathrm{~m}$ sub-bottom (Core 574C-5).

Correlation with other diatom zones: The $C$. elegans Zone is equivalent to the middle part of the $B$. veniamini Zone of Jousé (1973), and it closely approximates the limits of the Coscinodiscus rhombicus Zone of Weaver and Gombos (1981) and Gombos and Ciesielski (1983) (Barron, 1983) (Fig. 2).

\section{Triceratium pileus Zone}

Category: Interval zone.

Author: Barron (1983).

Definition: Interval containing Triceratium pileus between the last occurrence of Craspedodiscus elegans and the first occurrence of Denticulopsis nicobarica (Grunow) Simonsen.

Secondary markers: As stated, the first occurrences of Nitzschia maleinterpretaria and Triceratium pileus approximate the base of the $T$. pileus Zone in Leg 85 sediments. The last occurrence of Triceratium pileus $(17.6 \mathrm{Ma})$ slightly postdates the zone's top.

Age: Early Miocene, 18.7 Ma (extrapolated age) to 17.8 Ma (paleomagnetic tie, Hole 575A).

Remarks: The T. pileus Zone is well represented at Sites 574 and 575, where it contains the last occurrences of Thalassiosira spinosa (17.9 Ma) and Actinocyclus radionovae $(18.0 \mathrm{Ma})$.

Characteristic flora: Cestodiscus pulchellus and Synedra jouseana are common diatoms within the T. pileus Zone. Assemblages in the lower part of the zone at Site 575 are dominated by fragments of a diatom similar to Ethmodiscus rex (Wallich) Hendey (Samples 575A-9, CC through 575A-12,CC).

Correlation: At Site 575, the T. pileus Zone brackets the $\mathrm{CN} 1 \mathrm{c} / \mathrm{CN} 2$ (calcareous nannofossil) and Stichocorys delmontensis/S. wolffii (radiolarian) zonal boundaries, and is equivalent to the upper part of planktonic foraminiferal Zone N5; these correlations are consis- tent with the results of Barron (1983) and Barron et al. (in press).

Correlation with other diatom zones: The $T$. pileus Zone is equivalent to the upper middle part of the Bogorovia veniamini Zone of Jousé (1973) and the lower part of the Nitzschia maleinterpretaria Zone of Weaver and Gombos (1981) (Barron, 1983) (Fig. 2).

\section{Denticulopsis nicobarica Zone}

Category: Partial-range zone.

Author: Barron (1983).

Definition: Interval from the first occurrence of Denticulopsis nicobarica to the first occurrence of Cestodiscus peplum.

Subzones: The last occurrence of Thalassiosira bukryi Barron (17.0 Ma) marks the top of Subzone A and the base of Subzone B.

Secondary markers: The last occurrence of Triceratium pileus $(17.6 \mathrm{Ma})$ approximates the base of the $D$. $n i$ cobarica Zone, and the last occurrences of Synedra miocenica Schrader (16.5 Ma) and Thalassiosira fra$g a(16.3$ to $16.1 \mathrm{Ma})$ approximate the top of the zone.

Age: Early Miocene, 17.8 to $16.4 \mathrm{Ma}$ (paleomagnetic calibration, Hole 575A).

Remarks: The $D$. nicobarica Zone also contains the last occurrences of Thalassiosira spumellaroides $(17.5 \mathrm{Ma})$, Coscinodiscus lewisianus var. robustus (17.4 Ma), and Raphidodiscus marylandicus (16.7 Ma), and the first occurrences of Cestodiscus pulchellus var. maculatus (17.4 Ma), Coscinodiscus lewisianus var. similis Rattray (17.4 Ma), Craspedodiscus coscinodiscus Ehrenberg s. str. (17.3 Ma), Annellus californicus (17.3 Ma), and Denticulopsis sp. cf. D. kanayae Akiba (16.9 Ma) (Table 3; Barron, 1983).

Characteristic flora: See Table 4 (Hole 575A) and Table 5 (Hole 574) for quantitative diatom data on the D. nicobarica Zone.

Correlation: At Sites 573, 574, and 575, the D. nicobarica Zone correlates with upper Zone N6 to lower Zone N8 (planktonic foraminifers), upper Zone CN2 to upper Zone CN3 (calcareous nannofossils), and middle Stichocorys wolffii Zone to middle Calocycletta costata Zone (radiolarians), correlations supported by Barron (1983) and Barron et al. (in press).

Correlation with other diatom zones: The $D$. nicobarica Zone is correlative with the Actinocyclus ingens Zone of Barron (1980a) of the North Pacific and with the upper part of the Nitzschia maleinterpretaria Zone of Weaver and Gombos (1981) (Fig. 3).

\section{Cestodiscus peplum Zone}

Category: Taxon-range zone.

Author: Barron (1983).

Definition: Interval of the total range of Cestodiscus peplum Brun.

Subzones: The last occurrence of Annellus californicus Tempere within the $C$. peplum Zone $(15.0 \mathrm{Ma})$ defines the top of Subzone A and the base of Subzone B. 
Table 4. Percent planktonic diatoms through the Denticulopsis nicobarica Zone of Hole 575A.

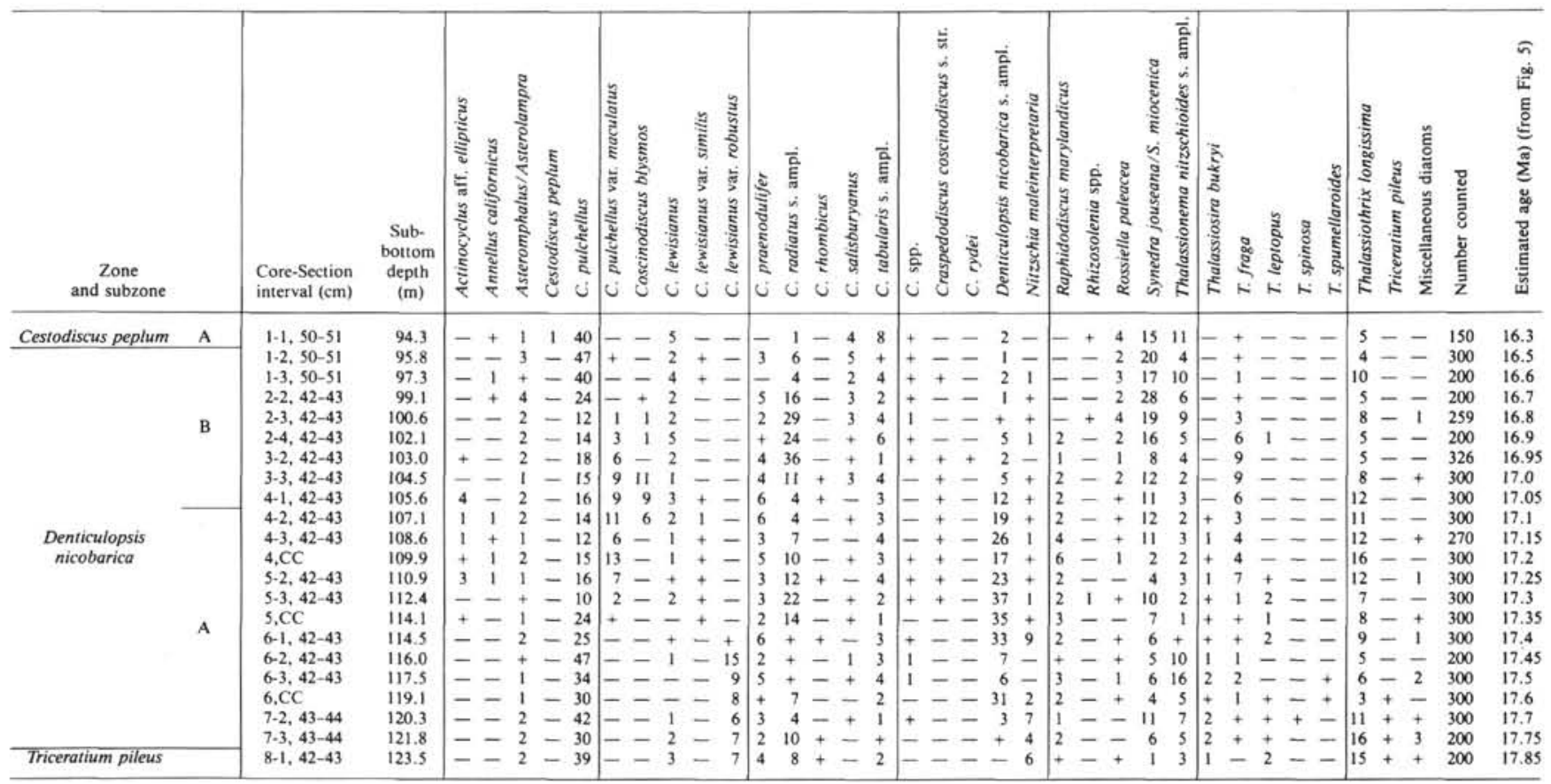

Note: + means $<1 \%$ or encountered after the count; - means not encountered.

Secondary markers: As stated, the last occurrences of Synedra miocenica $(16.5 \mathrm{Ma})$ and Thalassiosira fraga (16.3 to $16.1 \mathrm{Ma}$ ) approximate the base of the C. peplum Zone. The first occurrence of Actinocyclus ellipticus var. spiralis Barron, n. var. (14.2 to $14.1 \mathrm{Ma}$ ) corresponds closely to the top of the zone.

Age: Latest early Miocene to early middle Miocene, 16.4 Ma (paleomagnetic calibration, Hole 575A) to 14.2 Ma (paleomagnetic calibration, Burckle, 1978).

Remarks: The following last occurrences are within the C. peplum Zone: Denticulopsis sp. cf. D. kanayae ( 16.0 Ma), Coscinodiscus lewisianus var. similis (15.7 Ma), Nitzschia maleinterpretaria (15.6 Ma), Coscinodiscus praenodulifer (15.5 to $15.4 \mathrm{Ma}$ ), and C. blysmos Barron (14.4 Ma). The first occurrences of Actinocyclus ingens Rattray in the tropics (15.5 Ma), Thalassiosira tappanae Barron, n. sp. (14.4 Ma), and Actinocyclus ellipticus (14.4 to $14.3 \mathrm{Ma}$ ) also fall within the C. peplum Zone. An isolated occurrence of the middle- to high-latitude species Denticulopsis lauta (15.9 to 15.9 $\mathrm{Ma}$ ) in the lower part of the zone, reported by Barron (1983), has also been observed at Sites 573, 574, and 575 (Table 3). At Sites 572 and 574, isolated specimens of Denticulopsis hustedtii (Simonsen and Kanaya) Simonsen are observed as low as the 14.2-Ma level, the top of the $C$. peplum Zone. These occurrences more closely approximate the first occurrence of $D$. hustedtii in the middle- to high-latitude North Pacific (Barron, 1981a).

Characteristic flora: See Table 5 (Hole 574) and Table 6 (Hole 572D) for quantitative diatom data on the $C$. peplum Zone.
Correlation: In Leg 85 sediments, the $C$. peplum Zone correlates with lower Zone N8 to middle Zone N10 (planktonic foraminifers), middle Zone $\mathrm{CN} 3$ to upper Zone CN4 (calcareous nannofossils), and middle Calocycletta costata Zone to lower Dorcadospyris alata Zone (radiolarians). These results are generally consistent with those of Barron (1983) and Barron et al. (in press), although the top of $\mathrm{CN} 4$ appears relatively lower in Leg 85 sediments.

Correlation with other diatom zones: The $C$. peplum Zone correlates closely with the Denticulopsis lauta Zone (of Barron, 1980a, and Barron and Keller, 1983) of the North Pacific, and with the Coscinodiscus lewisianus and Nitzschia grossepunctata zones (Weaver and Gombos, 1981) of the Southern Ocean (Barron, in press) (Fig. 3).

\section{Coscinodiscus lewisianus Zone}

Category: Partial-range zone.

Author: Barron (in press).

Definition: Interval from the last occurrence of Cestodiscus peplum to the last occurrence of Coscinodiscus lewisianus Greville.

Secondary markers: The first occurrence of Actinocyclus ellipticus var. spiralis (14.2 to $14.1 \mathrm{Ma}$ ) approximates the base of the $C$. lewisianus Zone. The last occurrences of Cestodiscus pulchellus (13.6 to 13.5 $\mathrm{Ma})$, Coscinodiscus salisburyanus Lohman (13.5 to 13.4 Ma), and Annellus californicus (13.5 to $13.4 \mathrm{Ma}$ ), and the first occurrence of Coscinodiscus gigas var. diorama (Schmidt) Grunow (13.6 to $13.5 \mathrm{Ma}$ ), all fall near the top of the zone. 
Table 5. Percent planktonic diatoms in Cores 9 to 31 of Hole 574.

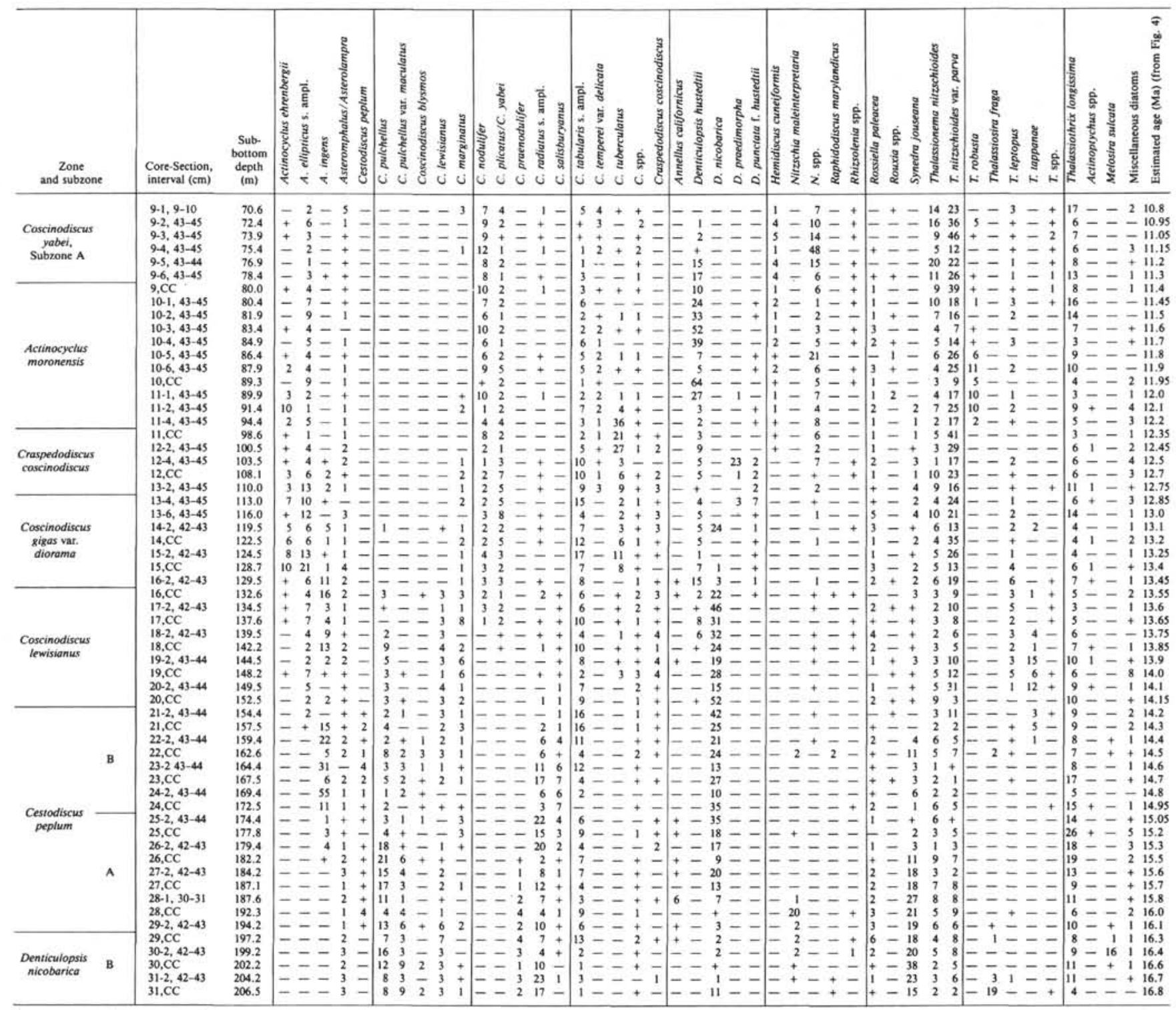

Note: + means $\langle 1 \%$ or encountered after the count; - means not encountered. 300 specimens were counted.

Age: Middle Miocene, 14.2 Ma to $13.5 \mathrm{Ma}$ (ages extrapolated, Barron et al., in press).

Remarks: Numerous datum levels are present within the relatively short ( 0.7 m.y. duration) C. lewisianus Zone, presumably reflecting response to global cooling and floral turnover in the early middle Miocene (Woodruff et al., 1981; Keller and Barron, 1983). First occurrences include Coscinodiscus tuberculatus Greville (14.0 Ma), Triceratium cinnamomeum Greville (13.9 to $13.8 \mathrm{Ma})$, Coscinodiscus plicatus Grunow (13.9 to 13.8 Ma), Coscinodiscus nodulifer Schmidt (13.7 Ma), and Denticulopsis punctata f. hustedtii (Schrader) Simonsen (13.7 Ma). Cestodiscus pulchellus var. maculatus (13.9 Ma) and Thalassiosira tappanae (13.8 Ma) have last occurrences within the $C$. lewisianus Zone.
Denticulopsis hustedtii became established in the tropics about $13.9 \mathrm{Ma}$, after isolated incursions from middle latitudes around 14.2 Ma.

Characteristic flora: See Table 5 (Hole 574) and Table 6 (Hole 572D) for quantitative diatom data on the $C$. lewisianus Zone.

Correlation: In Leg 85 sediments, the $C$. lewisianus Zone is equivalent to upper Zone N10 and Zone N11 (planktonic foraminifers), upper Zone CN4 to lower Zone CN5 (calcareous nannofossils), and the middle part of the Dorcadospyris alata Zone (radiolarians). At Site 573, Nigrini (this volume) records the Diartus petterssoni Zone (radiolarians) relatively lower, with respect to the other microfossil zones, than in the other Leg 85 holes. These results are consistent with the cor- 
Table 6. Percent planktonic diatoms in Cores 12 to 33 of Hole 572D.

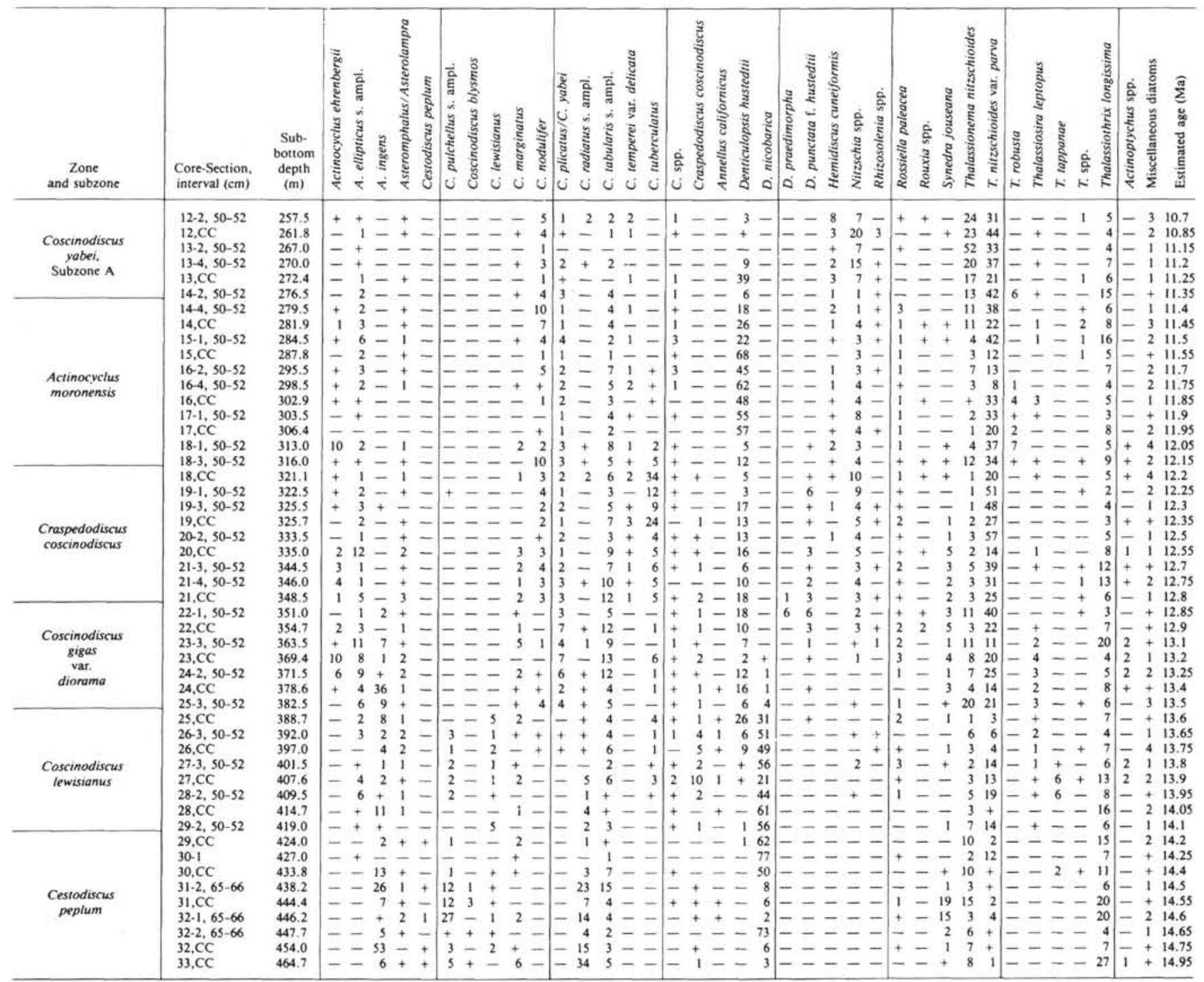

Note: + means $<1 \%$ or encountered after the count; - means not encountered. 300 specimens were counted.

relations of Barron et al. (in press), although the $\mathrm{CN} 4 /$ CN5 boundary appears slightly higher in Leg 85 sediments.

Correlation with other diatom zones: The $C$. lewisianus Zone correlates with the uppermost part of the Denticulopsis lauta Zone and Subzone a of the D. hustedtii-D. lauta Zone (of Barron, 1980a, and Barron and Keller, 1983) of the North Pacific, and with the uppermost Nitzschia grossepunctata to lowermost $N$. denticuloides zones (Weaver and Gombos, 1981) of the Southern Ocean (Barron, in press) (Fig. 3).

\section{Coscinodiscus gigas var. diorama Zone}

Category: Interval zone.

Author: Barron (in press).

Definition: Interval containing Coscinodiscus gigas var. diorama between the last occurrence of Coscinodiscus lewisianus and the first occurrence of $C$. temperei var. delicata Barron.
Secondary markers: The last occurrences of Cestodiscus pulchellus, Coscinodiscus salisburyanus, and Annellus californicus and the first occurrence of $C$. gigas var. diorama approximate the base of the $C$. gigas var. diorama Zone, and the last occurrence of Actinocyclus ingens (12.8 to $12.5 \mathrm{Ma}$ ) in the tropics is near the top of the zone.

Age: Middle Miocene, 13.5 Ma (extrapolated, Barron et al., in press) to $12.8 \mathrm{Ma}$ (paleomagnetic calibration, Burckle et al., 1982).

Remarks: The $C$. gigas var. diorama Zone contains the first occurrence of Nitzschia porteri sensu Burckle (1972) (13.1 to $12.9 \mathrm{Ma})$ and the last occurrence of Denticulopsis nicobarica (13.2 Ma).

Characteristic flora: See Table 5 (Hole 574) and Table 6 (Hole 572D) for quantitative diatom data on the $C$. gigas var. diorama Zone.

Correlation: In Leg 85 sediments, the $C$. gigas var. diorama Zone is equivalent to Zone N12 (planktonic for- 
aminifers), and it brackets the $\mathrm{CN} 5 \mathrm{a} / \mathrm{CN} 5 \mathrm{~b}$ subzonal boundary of calcareous nannofossils. At Sites 574 and 575 , the $C$. gigas var. diorama Zone correlates with the upper Dorcadospyris alata Zone of radiolarians, whereas at Sites 572 and 573 a correlation with the lower Diartus petterssoni Zone is suggested. Correlation with the upper $D$. alata Zone is favored by Barron et al. (in press); comparison of the various microfossil biostratigraphies (Barron et al., this volume) suggests that the $D$. alata/D. petterssoni zonal boundary is diachronous between Sites 572-573 and Sites 574575.

Correlation with other diatom zones: The $C$. gigas var. diorama Zone correlates with Subzone b of the Denticulopsis hustedtii-D. lauta Zone of the North Pacific, and with a lower part of the Nitzschia denticuloides Zone of the Southern Ocean (Barron, in press) (Fig. 3).

\section{Craspedodiscus coscinodiscus Zone}

Category: Concurrent-range zone.

Author: Barron (in press).

Definition: Interval from the first occurrence of Coscinodiscus temperei var. delicata to the last occurrence of Craspedodiscus coscinodiscus.

Secondary markers: The last occurrence of Actinocyclus ingens in the tropics approximates the base of the $C$. coscinodiscus Zone. The last occurrences of Coscinodiscus gigas var. diorama (12.3 Ma) and Synedra jouseana $(12.3$ to $12.1 \mathrm{Ma})$ and the first occurrences of Thalassionema robusta Schrader (12.3 to $12.2 \mathrm{Ma})$ and Rossiella paleacea var. elongata Barron (12.3 to 12.2 Ma) all nearly coincide with the zone's top.

Age: Middle Miocene, $12.8 \mathrm{Ma}$ (paleomagnetic calibration, Burckle et al., 1982) to $12.2 \mathrm{Ma}$ (extrapolated age, Barron et al., in press).

Remarks: The first occurrences of Rossiella praepaleacea (Schrader) Gersonde (12.7 Ma) and Hemidiscus cuneiformis Wallich (12.5 Ma) and the last occurrence of Actinocyclus ellipticus var. spiralis (12.4 to $12.3 \mathrm{Ma}$ ) are within the $C$. coscinodiscus Zone.

Characteristic flora: See Table 5 (Hole 574) and Table 6 (Hole 572D) for quantitative diatom data on the $C$. coscinodiscus Zone.

Correlation: The $C$. coscinodiscus Zone is equivalent to planktonic foraminiferal Zone N13, calcareous nannofossil Subzone CN5b to lower Zone CN6, and the lower Diartus petterssoni Zone of radiolarians in Leg 85 sediments. These correlations are supported by Barron et al. (in press).

Correlation with other diatom zones: The lower part of Subzone c of the Denticulopsis hustedtii-D. lauta Zone of the North Pacific, and a middle part of the Nitzschia denticuloides Zone of the Southern Ocean, are correlative with the $C$. coscinodiscus Zone (Barron, in press) (Fig. 3).

\section{Actinocyclus moronensis Zone}

Category: Partial-range zone.

Author: Barron (in press).
Definition: Interval from the last occurrence of Craspedodiscus coscinodiscus to the last occurrence of Actinocyclus moronensis Deby.

Secondary markers: The last occurrences of Coscinodiscus gigas var. diorama and Synedra jouseana and the first occurrences of Thalassionema robusta and Rossiella paleacea var. elongata correspond closely to the base of the $A$. moronensis Zone. The first occurrence of Actinocyclus ellipticus f. lanceolata Kolbe (11.4 Ma) slightly predates the top of the zone.

Age: Latest middle Miocene to earliest late Miocene, 12.2 Ma (extrapolated age, Barron et al., in press) to 11.3 Ma (paleomagnetic calibration, Burckle, 1978).

Remarks: The last occurrence of Denticulopsis punctata f. hustedtii $(12.1 \mathrm{Ma})$ and the last consistent occurrence of Coscinodiscus tuberculatus (12.0 Ma) fall within the $A$. moronensis Zone.

Characteristic flora: See Table 5 (Hole 574) and Table 6 (Hole 572D) for quantitative diatom data on the $A$. moronensis Zone.

Correlation: The $A$. moronensis Zone is equivalent to planktonic foraminiferal Zones N14 and N15, calcareous nannofossil Zone CN7, and the middle part of the Diartus petterssoni Zone of radiolarians in Leg 85 sediments. These correlations are supported by Barron et al. (in press).

Correlation with other diatom zones: The $A$. moronensis Zone correlates with the upper part of Subzone C of the Denticulopsis hustedtii-D. lauta Zone of the North Pacific and with the upper part of the Nitzschia denticuloides Zone of the Southern Ocean (Barron, in press) (Fig. 3).

\section{Coscinodiscus yabei Zone}

Category: Partial-range zone.

Author: Burckle, 1972 (top); Barron, in press (base).

Definition: Interval from the last occurrence of Actinocyclus moronensis to the last occurrence of Coscinodiscus yabei Kanaya.

Subzones: Barron (in press) proposed the first occurrence of Thalassiosira burckliana to define the Subzone A/Subzone B boundary.

Secondary markers: The first occurrence of Actinocyclus ellipticus $\mathrm{f}$. lanceolata slightly predates the base of the zone, and the first occurrence of Nitzschia cylindrica Burckle s. ampl. (8.7 to 8.6 Ma) coincides with the top of the zone.

Age: Late Miocene, 11.3 to $8.6 \mathrm{Ma}$ (paleomagnetic calibrations, Burckle, 1978).

Remarks: Restricted ranges of Coscinodiscus vetustissimus var. javanica Reinhold (11.2 to $10.7 \mathrm{Ma}$, Burckle, 1978), C. loeblichii Barron, n. sp. (about 10.5 to $9.4 \mathrm{Ma}$ ), and C. yabei var. ellipticus Barron, n. var. (about 9.8 to $9.4 \mathrm{Ma}$ ) all fall within the $C$. yabei Zone. Nitzschia fossilis (Frenguelli) Kanaya $(9.8 \mathrm{Ma})$ and Coscinodiscus nodulifer var. cyclopus Jousé (8.9 to $8.8 \mathrm{Ma}$ ) have first occurrences within the C. yabei Zone, and Denticulopsis hustedtii last occurs (11.2 to $10.5 \mathrm{Ma}$ ) within the tropics within the zone.

Burckle (1978) correlated the first occurrence of Thalassiosira burckliana with the uppermost part of 
paleomagnetic Chron 9 in the equatorial Pacific, but admitted that Chron 9 appears greatly abbreviated in many of his piston cores (L. H. Burckle, pers. comm., 1981). Hiatus NH5 of Keller and Barron (1983) removes sediments equivalent to Chron 9 throughout the equatorial Pacific, so it is possible that Burckle's calibration of the first occurrence of $T$. burckliana to paleomagnetics was affected by a hiatus in his piston cores. On Figure 2, the sediment accumulation rate curve for Site 572, the middle late Miocene trend established by paleomagnetically calibrated diatom datums has been continued to intersect the late middle Miocene trend established by diatom datums, and the extrapolated age of $10.5 \mathrm{Ma}$ (Table 3 ) has been obtained for the first occurrence of $T$. burckliana. Site 572 was within the high-productivity zone along the equator in the eastern Pacific during the early late Miocene, and it is the most likely of the Leg 85 sites to have a complete section representing that interval. Indeed, compression of datum levels within the 10.5 to $9.8 \mathrm{Ma}$ interval at Sites 573, 574, and 575 (Table 3) indicates the likelihood of hiatuses there. However, see also Barron et al. (this volume).

Characteristic flora: See Tables 5 and 7 (Hole 574) and Tables 6 and 7 (Hole 572D) for quantitative diatom data through the $C$. yabei Zone.

Correlation: The $C$. yabei Zone is equivalent to planktonic foraminiferal Zone N16 to lowermost Zone N17, calcareous nannofossil Subzone CN8, and upper Diartus petterssoni Zone to lower Didymocyrtis antepenultima Zone (radiolarians) in Leg 85 sediments.

Correlation with other diatom zones: The $C$. yabei Zone correlates with Subzone d of the Denticulopsis hustedtii-D. lauta Zone through Subzone a of the $D$. hustedtii Zone of the North Pacific, and with the uppermost Nitzschia denticuloides Zone through the $D$. hustedtii-D. lauta Zone of the Southern Ocean (Barron, in press; Ciesielski, 1983) (Fig. 3).

\section{Nitzschia porteri Zone}

Category: Interval zone.

Author: Burckle (1972).

Definition: Interval containing Nitzschia porteri between the last occurrence of Coscinodiscus yabei and the first occurrence of Nitzschia miocenica.

Subzones: Barron (in press) proposed the last occurrence of Thalassiosira burckliana $(8.0 \mathrm{Ma})$ to define the Subzone A/Subzone B boundary.

Secondary markers: The first occurrence of Nitzschia cylindrica s. ampl. approximates the base of the $N$. porteri Zone, and the last occurrence of Rossiella paleacea (7.4 Ma) slightly predates the top of the zone.

Age: Late Miocene, 8.6 to $7.3 \mathrm{Ma}$ (paleomagnetic calibrations, Burckle, 1978).

Remarks: The $N$. porteri Zone contains the first occurrences of Nitzschia reinholdii Kanaya and Koizumi s. ampl. (8.0 Ma) and N. marina Grunow (8.2 to 8.1 Ma) and the last occurrences of Actinocyclus ellipticus var. javanica Reinhold (8.0 Ma) and Coscinodiscus nodulifer var. cyclopus (7.9 Ma-within the Miocene). The first occurrence of $N$. reinholdii predates by more than 1 m.y. Burckle's (1978) calibration of that datum with lower paleomagnetic Chron 6, but it is consistent with the results of Sancetta (1982), who found $N$. reinholdii to range to the equivalent of the middle of Chron 7 at DSDP Site 503 in the eastern equatorial Pacific.

Characteristic flora: See Table 7 (Holes 574 and 572D) for quantitative diatom data on the $N$. porteri Zone.

Correlation: In Leg 85 sediments, the $N$. porteri Zone is equivalent to lower planktonic foraminiferal Zone N17 and to part of calcareous nannofossil Zone $\mathrm{CN} 8$, and it brackets the Didymocyrtis antepenultima/D. penultima zonal boundary of radiolarians. The calcareous nannofossil correlation appears somewhat old, because elsewhere in the Pacific, the $N$. porteri Zone contains the CN8/CN9 boundary within Subzone A (Barron et al., in press; Keller et al., 1982) (Fig. 3).

Correlation with other diatom zones: The $N$. porteri Zone correlates with the lower part of Subzone B of the Denticulopsis hustedtii Zone of the North Pacific, the lower part of Barron's (1981b) Thalassiosira antiqua Zone of the California area, and the lower part of the D. hustedtii Zone of the Southern Ocean (Barron, in press).

\section{Nitzschia miocenica Zone}

Category: Partial-range zone.

Author: Burckle (1972).

Definition: Interval between the first occurrence of Nitzschia miocenica Burckle and the first occurrence of Thalassiosira convexa Mukhina.

Subzones: The first occurrence of Thalassiosira praeconvexa Burckle (6.3 Ma) defines the Subzone A/Subzone B boundary (Burckle, 1972).

Secondary markers: The last occurrence of Rossiella paleacea slightly predates the base of the $N$. miocenica Zone, and the first occurrence of Thalassiosira miocenica $(6.1 \mathrm{Ma})$ closely approximates the zone's top.

Age: Late Miocene, 7.3 to $6.1 \mathrm{Ma}$ (paleomagnetic calibration, Burckle, 1978).

Remarks: Nitzschia porteri sensu Burckle (1972) has its last occurrence within the $N$. miocenica Zone (at about 6.8 Ma). Burckle (1978) noted only a slight overlap between the first occurrence of $N$. miocenica $(7.3 \mathrm{Ma})$ and the last occurrence of $N$. porteri. At DSDP Site 503 in the eastern equatorial Pacific, Sancetta (1982) records an overlap of more than three cores between the two species, but Sancetta's (1982) extinction level for $N$. porteri coincides with the first occurrence of Thalassiosira praeconvexa (6.3 Ma). Thus, the Leg 85 result for the extinction level of $N$. porteri lies approximately halfway between the results of Burckle (1978) and Sancetta (1982).

Characteristic flora: See Table 7 (Holes 574 and 572D) for quantitative diatom data on Subzone A and Baldauf (this volume; Holes 573, 572A, and 572D) for quantitative diatom data on Subzone B of the $N$. miocenica Zone.

Correlation: The $N$. miocenica Zone is equivalent to middle planktonic foraminiferal Zone N17, upper calcareous nannofossil Zone CN8, and the upper Didymocyrtis penultima Zone (radiolarians) in Leg 85 sediments. Elsewhere in the Pacific, the zone is restricted 
Table 7. Percent planktonic diatoms in Cores 5 to 11 of Hole 572D and Sample 574-6-6, $43-44 \mathrm{~cm}$ and Cores 7 and 8 of Hole 574.

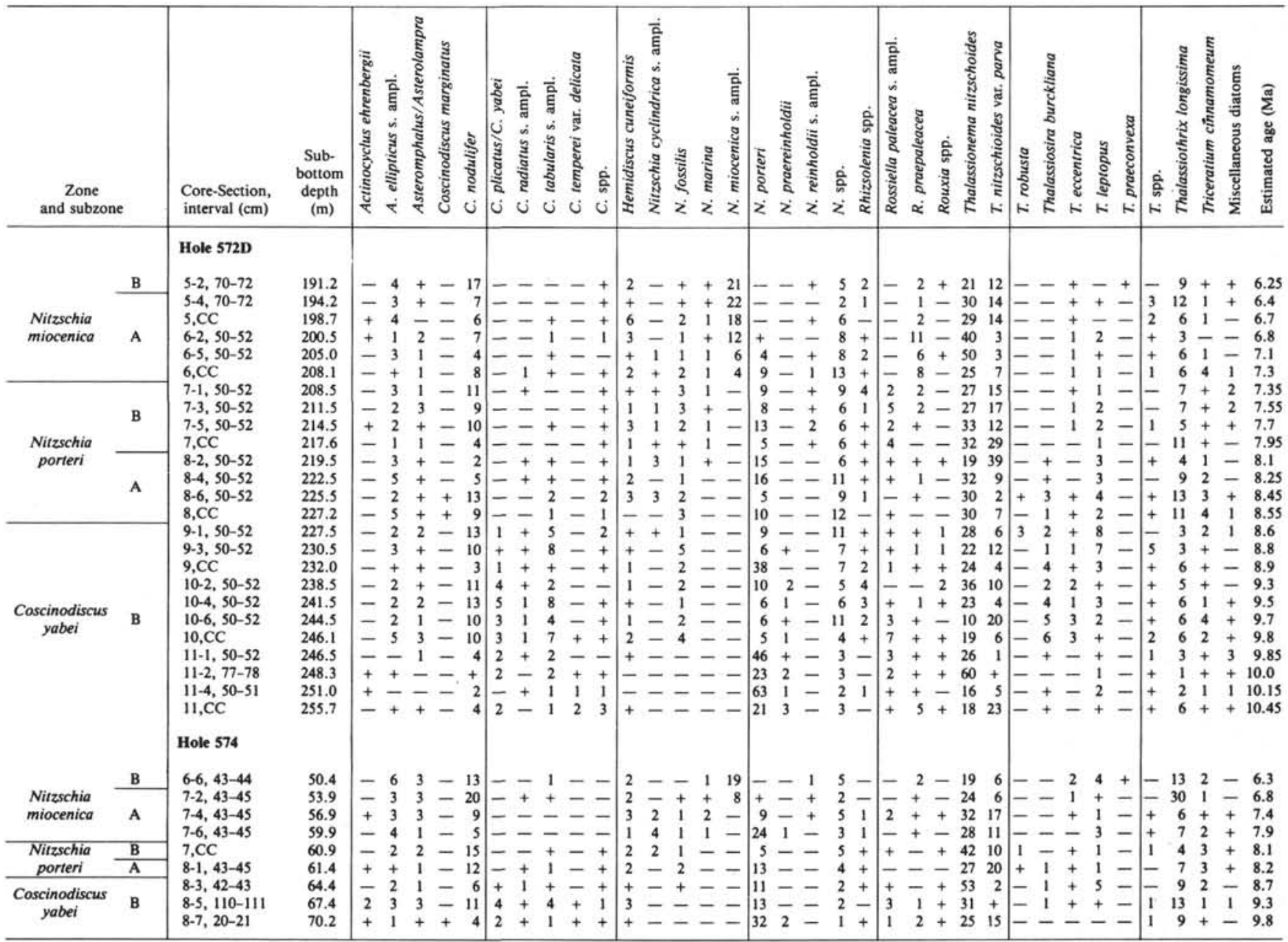

Note: + means $<1 \%$ or encountered after the count; - means not encountered. 300 specimens were counted.

to Zone $\mathrm{CN} 9$ and brackets the $\mathrm{CN} 9 \mathrm{a} / \mathrm{CN} 9 \mathrm{~b}$ boundary (Keller et al., 1982; Barron, in press; Haq et al., 1980). It therefore appears that the CN8/CN9 boundary is placed substantially above its generally accepted position in Leg 85 sediments.

Correlation with other diatom zones: The Nitzschia miocenica Zone correlates with the upper part of Subzone b of the $D$. hustedtii Zone to lowermost $D$. kamtschatica Zone of the North Pacific, the upper part of the Thalassiosira antiqua Zone to lowermost Nitzschia reinholdii Zone (Barron, 1981b) of the California area, and the middle part of the $D$. hustedtii Zone of the Southern Ocean (Barron, in press; Ciesielski, 1983) (Fig. 3).

\section{Thalassiosira convexa Zone}

Category: Partial-range zone.

Author: Burckle (1972).

Definition: Interval from the first occurrence of Thalassiosira convexa to the first occurrence of Nitzschia jouseae Burckle.

Subzones: Burckle (1972) defined three subzones: Subzone A, from the base of the zone to the last occur- rence of Thalassiosira praeconvexa $(5.8 \mathrm{Ma})$; Subzone B, from the top of Subzone A to the last occurrence of Thalassiosira miocenica Schrader (5.1 Ma); and Subzone C, from the top of Subzone B to the top of the zone.

Secondary markers: The first occurrence of Thalassiosira miocenica closely approximates the base of the $T$. convexa Zone.

Age: Latest Miocene to earliest Pliocene, 6.1 to $4.6 \mathrm{Ma}$ (paleomagnetic calibrations, Burckle, 1978). The Subzone B/Subzone $\mathrm{C}$ boundary coincides with the Miocene/Pliocene boundary (Burckle, 1978).

Remarks: The Thalassiosira convexa Zone contains the last occurrences of Rossiella praepaleacea $(6.0 \mathrm{Ma})$, Nitzschia miocenica Burckle (5.6 Ma), Nitzschia miocenica var. elongata Burckle (5.65 Ma), and Asterolampra acutiloba Forti (5.35 Ma). Thalassiosira oestrupii (Ostenfeld) Proshkina-Lavrenko s. str. first occurs at the Subzone B/Subzone C boundary or Miocene/Pliocene boundary (5.1 Ma).

Correlation: The Thalassiosira convexa Zone is equivalent to upper planktonic foraminiferal Zone N17 to lower N19 and to calcareous nannofossil Zone CN9 
through Subzone CN10b, and it closely approximates the Stichocorys peregrina Zone of radiolarians in Leg 85 sediments.

Correlation with other diatom zones: The $T$. convexa Zone correlates with most of Subzones a and b of the Denticulopsis kamtschatica Zone of the North Pacific, with the upper Nitzschia reinholdii Zone to lower Thalassiosira oestrupii Zone (Barron, 1981b) of the California area, and the upper $D$. hustedtii Zone of the Southern Ocean (Barron, in press; Ciesielski, 1983) (Fig. 3).

\section{Nitzschia jouseae Zone}

Category: Partial-range zone.

Author: Burckle (1972).

Definition: Interval from the first occurrence of Nitzschia jouseae to the first occurrence of Rhizosolenia praebergonii Mukhina.

Age: Early Pliocene to early late Pliocene, 4.5 to $3.0 \mathrm{Ma}$ (paleomagnetic calibration, Burckle, 1978).

Remarks: Within the $N$. jouseae Zone are the last occurrences of Nitzschia cylindrica (4.4 Ma) and Actinocyclus ellipticus $\mathrm{f}$. lanceolata ( 3.5 to $3.2 \mathrm{Ma}$; oldest at Site 572-Table 3) and the first occurrences of Asterolampra elegans Greville ( $3.9 \mathrm{Ma}$ ) and Thalassiosira convexa var. convexa Schrader (3.6 Ma). Burckle (1978) also records the first occurrence of Coscinodiscus africanus Janisch at about $3.7 \mathrm{Ma}$, but this datum was not searched for in Leg 85 sediments.

Characteristic flora: See Baldauf (this volume) for quantitative diatom data from the $N$. jouseae Zone of Sites 572 and 573.

Correlation: In Leg 85 sediments, the Nitzschia jouseae Zone is equivalent to upper planktonic foraminiferal Zone N19, Subzone CN10c and Zone CN11 of calcareous nannofossils, and the Spongaster pentas Zone of radiolarians.

Correlation with other diatom zones: The $N$. jouseae Zone correlates with Subzone c of the Denticulopsis kamtschatica Zone of the North Pacific. For the Southern Ocean, the $N$. jouseae Zone is equivalent to the Nitzschia reinholdii to upper $N$. interfrigidaria zones of Weaver and Gombos (1981) and the Nitzschia reinholdii to middle $N$. interfrigidaria-Coscinodiscus vulnificus zones of Ciesielski (1983) (Barron, in press; Ciesielski, 1983) (Fig. 3).

\section{Rhizosolenia praebergonii Zone}

Category: Partial-range zone.

Author: Burckle (1972).

Definition: Interval from the first occurrence of Rhizosolenia praebergonii to the first occurrence of Pseudoeunotia doliolus Wallich.

Subzones: Burckle (1972) defined three subzones: Subzone A, from the base of the zone to the last occurrence of Nitzschia jouseae (2.6 Ma); Subzone B, from the top of Subzone A to the last occurrence of Thalassiosira convexa $(2.1 \mathrm{Ma})$; and Subzone C, from the top of Subzone B to the top of the zone.

Secondary markers: The last occurrence of Rhizosolenia praebergonii $(1.8 \mathrm{Ma})$ slightly predates the top of the zone (Burckle and Trainer, 1979).
Age: Late Pliocene, 3.0 to $1.8 \mathrm{Ma}$ (paleomagnetic calibrations, Burckle, 1978).

Characteristic flora: Quantitative diatom data for the $R$. praebergonii Zone of Sites 572 and 573 are given in Baldauf (this volume).

Correlation: The $R$. praebergonii Zone is equivalent to planktonic foraminiferal Zone N21 and to calcareous nannofossil Zone CN12, and it brackets the Spongaster pentas/Pterocanium prismaticum zonal boundary of radiolarians in Leg 85 sediments.

Correlation with other diatom zones: The $R$. praebergonii Zone correlates with the Denticulopsis seminae var. fossilis-D. kamtschatica and $D$. seminae var. fossilis zones of the North Pacific. For the Southern Ocean, the $R$. praebergonii Zone correlates with the upper part of the Nitzschia interfrigidaria through Coscinodiscus kolbei-Rhizosolenia barboi zones of Weaver and Gombos (1981), and with the upper $N$. interfrigidaria-C. vulnificus through Coscinodiscus kolbei-Rhizosolenia barboi zones of Ciesielski (1983) (Barron, in press; Ciesielski, 1983) (Fig. 3).

\section{Nitzschia reinholdii Zone}

Category: Concurrent-range zone.

Author: Burckle (1977).

Definition: Interval from the first occurrence of Pseudoeunotia doliolus to the last occurrence of Nitzschia reinholdii.

Subzones: Burckle (1977) proposed two subzones, A and B, with the last occurrence of Rhizosolenia praebergonii var. robusta Burckle and Trainer (1.55 Ma) defining the subzonal boundary.

Secondary markers: The last occurrence of Rhizosolenia praebergonii var. praebergonii slightly predates the base of the P. doliolus Zone (Burckle and Trainer, 1979).

Age: Latest Pliocene to Quaternary, 1.8 to $0.65 \mathrm{Ma}$ (paleomagnetic calibration, Burckle, 1978). The Subzone $\mathrm{A} /$ Subzone $\mathrm{B}$ boundary closely approximates the Pliocene/Quaternary boundary.

Remarks: Although Sancetta (1982) reported that Nitzschia reinholdii disappeared just below the Jaramillo Event of the Matuyama paleomagnetic Chron at DSDP 503 in the eastern equatorial Pacific, its extinction in Leg 85 sediments is within the lower part of the Brunhes Chron (Table 3 and Weinreich and Theyer, this volume), consistent with the results of Burckle (1977) and Burckle and Opdyke (1977).

Characteristic flora: Thalassionema nitzschioides Grunow and Coscinodiscus nodulifer are common diatoms within the $N$. reinholdii Zone; Pseudoeunotia doliolus, Nitzschia marina, and N. reinholdii are frequent species. Rhizosolenia praebergonii var. robusta is fairly common within Subzone A.

Correlation: The $N$. reinholdii Zone is equivalent to planktonic foraminiferal Zone N22, lower calcareous nannofossil Zone CN13 to middle Zone CN14, and the upper part of the Pterocanium prismaticum Zone to uppermost Amphirhopalum ypsilon Zone of radiolarians in Leg 85 sediments.

Correlation with other diatom zones: The $N$. reinholdii Zone correlates with the Actinocyclus oculatus Zone through Subzone a of the Rhizosolenia curvirostris 
Zone of the North Pacific, and with the Rhizosolenia barboi-Nitzschia kerguelensis and Coscinodiscus elliptopora-Actinocyclus ingens zones of the Southern Ocean (Barron, in press; Ciesielski, 1983) (Fig. 3).

\section{Pseudoeunotia doliolus Zone}

Category: Partial-range zone.

Author: Burckle (1972, 1977).

Definition: Interval above the last occurrence of Nitzschia reinholdii containing Pseudoeunotia doliolus.

Age: Late Quaternary, 0.65 to $0 \mathrm{Ma}$ (paleomagnetic calibration, Burcke, 1977).

Remarks: See comments under $N$. reinholdii Zone.

Characteristic flora: Assemblages are dominated by Coscinodiscus nodulifer and Thalassiosira oestrupii. Nitzschia marina, Pseudoeunotia doliolus, Thalassiosira nitzschioides, and Asteromphalus spp. are secondarily common.

Correlation: The $P$. doliolus Zone is equivalent to upper planktonic foraminiferal Zone N22 and Zone N23, upper calcareous nannofossil Zone CN14 and Zone $\mathrm{CN} 15$, and the Collosphaera tuberosa and Buccinosphaera invaginata zones of radiolarians in Leg 85 sediments.

Correlation with other diatom zones: The $P$. doliolus Zone correlates with Subzone b of the Rhizosolenia curvirostris Zone and the Denticulopsis seminae Zone of the North Pacific, and with the Coscinodiscus lentigenosus Zone of the Southern Ocean (Barron, in press; Ciesielski, 1983) (Fig. 3).

\section{AGE-VERSUS-DEPTH PLOTS}

Estimated ages of diatom datum levels that have been calibrated directly and indirectly with paleomagnetic stratigraphy (Tables 1 to 3 ) and direct Leg 85 paleomagnetic stratigraphy (Weinreich and Theyer, this volume) have been used on Figure 4 to construct age-versus-depth plots for the upper Cenozoic of Sites 572 to 575 . The datums used include those of Burckle (1978), along with additions and modifications suggested by Barron et al. (in press). As stated in the preceding section, these plots allow the ages of secondary datum levels to be extrapolated and compared within the Leg 85 sections. In addition, rates of sediment accumulation can be compared between the sites, and hiatuses and greatly compressed intervals can be detected.

\section{Sediment Accumulation Rates}

Figure 4 shows that rates of sediment accumulation at eastern equatorial Site 572 were at least 1.7 times greater than those at central equatorial Sites 573 to 575 throughout the middle Miocene, late Miocene, and earliest Pliocene. Of the three central equatorial sites, Site 573 shows the highest rates of sediment accumulation between 0 and $11 \mathrm{Ma}$, reflecting its present position with the equatorial region of high productivity. Sediment accumulation rates between 1 and $4 \mathrm{Ma}$ are roughly comparable $(15 \mathrm{~m} / \mathrm{m} . \mathrm{y}$.) between eastern Site 572 and central Site 573 . For the middle Miocene (15.5 to $11 \mathrm{Ma})$, the central equatorial Pacific rates are higher $(20$ to $30 \mathrm{~m} /$ m.y.) at Site 574 than at Sites 573 and 575, correspond- ing to a time when Site 574 was within the high-productivity zone and Sites 573 and 575 were not. Early Miocene sediment accumulation rates were relatively high ( 18 to $20 \mathrm{~m} / \mathrm{m} . \mathrm{y}$.) at Sites 574 and 575 , indicating that both those sites were then within the region of high productivity.

\section{Hiatuses}

The near coincidence of the last occurrences of Craspedodiscus elegans (18.7 Ma; Sample 574C-5,CC) and Actinocyclus radionovae (18.0 Ma; Sample 574C-5-3, $43-45 \mathrm{~cm}$ ) indicates the possibility of a hiatus at about $235 \mathrm{~m}$ sub-bottom at Site 574. This hiatus would correspond in part to hiatus NH1 of Keller and Barron (1983), which is present throughout much of the central equatorial Pacific.

Compression of diatom datum levels in the upper part of Core 573B-14 (Table 3) suggests a hiatus from about 17.6 to $17.0 \mathrm{Ma}$ at Site 573 (Fig. 4). This hiatus (NH1b) has also been recognized at nearby Site 77 by Keller and Barron (1983). A sharp lithologic contact at $262.1 \mathrm{~m}$ subbottom in upper Core 573B-14, where white radiolarian-nannofossil oozes rest on white to very light brown radiolarian-nannofossil oozes and chalks and siliceous nannofossil oozes and chalks (see site chapter), is consistent with this hiatus.

Keller and Barron (1983) also proposed a second hiatus (NH1a) at Site 77, approximately $20 \mathrm{~m}$ below NH1b, at the base of Core 77B-30. Poor preservation of diatoms below $270 \mathrm{~m}$ at Site 573 hinders recognition of this second hiatus, which spans the interval of Subzone A of the Rossiella paleacea Zone (20.6 to $19.9 \mathrm{Ma}$ ), according to Barron et al. (in press); but a sharp lithologic contact in uppermost Core 573B-17 (290.6 m), between light brown nannofossil oozes above and white nannofossil oozes below, may correspond to this hiatus.

At Site 575 sediment accumulation rates decreased dramatically between 15.5 and $14.4 \mathrm{Ma}$ ( 82 to $74 \mathrm{~m}$ subbottom depth). This is also indicated by a relatively compressed planktonic foraminiferal Zone N9 at Site 575 (Saito, this volume). Although no hiatus is apparent, this interval does correspond in part with widespread hiatus NH2 (16.0 to 15.0 Ma) of Keller and Barron (1983).

Figure 4 also shows decreased sediment accumulation rates for Site 573 between 12.0 and $11.4 \mathrm{Ma}$, corresponding to the compression of the last-occurrence datum level of Coscinodiscus tuberculatus (12.0 Ma) (Sample 573B$5-1,68-70 \mathrm{~cm}$ ) and the last common occurrence of Denticulopsis hustedtii (11.5 Ma; see section on quantitative stratigraphy) (Sample 573B-4-5, 68-70 cm). This compressed interval corresponds in part to hiatus NH4 of Keller and Barron (1983) (12.0 to $11.0 \mathrm{Ma}$ ), which is widespread in the northeast Pacific, and also coincides with severe calcium carbonate dissolution at all the Leg 85 sites.

Hiatuses between 10.5 and $9.8 \mathrm{Ma}$ (hiatus NH4 of Keller and Barron, 1983) are present at Sites 573, 574, and 575 (Fig. 4), although Core 572D-11 (255.5 to $246 \mathrm{~m}$ sub-bottom) apparently is complete across that interval (Fig. 2). Compression of diatom datum levels in Section 1 of Core 573B-3, in lowermost Core 574-8, and in low- 


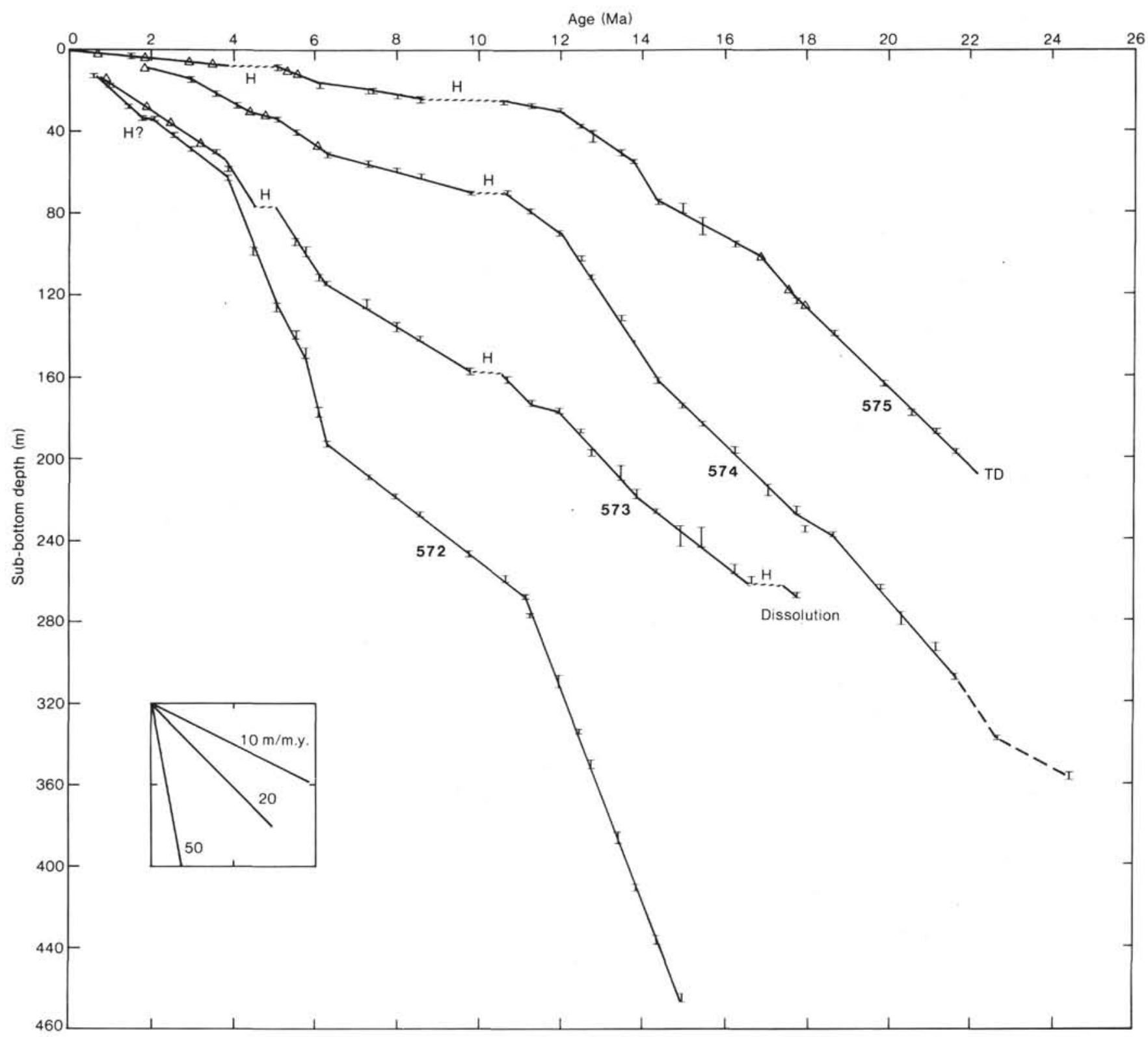

Figure 4. Age-versus-depth curves for the upper Cenozoic of DSDP Sites 572 to $575 . \Delta=$ paleomagnetic calibrations after Weinreich and Theyer (this volume); $\mathrm{H}=$ hiatus; $\mathrm{TD}=$ total depth. Vertical bars represent depth intervals in which diatom datums occur (see Tables 2 and 3 ). See also Barron et al. (this volume).

ermost Core 575-3 (Table 3) indicates hiatuses. At Sites 573 and 574 , the hiatuses coincide with distinctive purple-banded sediment units (see site chapters), but such a unit was not observed at Site 575 , where the hiatus is more extensive (10.5 to $8.6 \mathrm{Ma})$.

Near coincidence of the last occurrence of Thalassiosira miocenica (5.1 Ma; Sample 573-10-1, 65-66 cm) with the first occurrence of Nitzschia jouseae (4.5 Ma; Sample 573-9-5, 67-68 cm) indicates the probability of a hiatus (NH7 of Keller and Barron, 1983) at $76 \mathrm{~m}$ subbottom at Site 573. At Site 574, paleomagnetic stratigraphy suggests that this interval is present (Weinreich and Theyer, this volume; Fig. 4), but it is much compressed. At Site 575 a more extensive hiatus ( 5.1 to $3.6 \mathrm{Ma}$ ) removes sediments at the interval between Samples 5752-1, 52-53 cm and 575-1,CC.
Finally, a possible hiatus or greatly compressed interval is present in Section 4 of Core 572A-4, as indicated by the near coincidence of the last occurrence of Thalassiosira convexa (2.1 Ma; Sample 572A-4-5, 66-67 cm) and the first occurrence of Pseudoeunotia doliolus (1.8 Ma; Sample 572A-4-3, 66-67 cm).

\section{PALEOMAGNETIC CORRELATION, HOLE 575A}

On Figure 5 the paleomagnetic data of Weinreich and Theyer (this volume) for Cores 1 to 10 of Hole 575A are correlated with the polarity sequence from the middle of paleomagnetic Chron 16 (Anomaly 5C) to middle Chron 17 (Anomaly 5D). This interpretation supports paleomagnetic calibrations for the N6/N7 planktonic foraminiferal zonal boundary and the $\mathrm{CN} 2 / \mathrm{CN} 3$ calcareous nannofossil zonal boundary proposed by Ryan et al. 


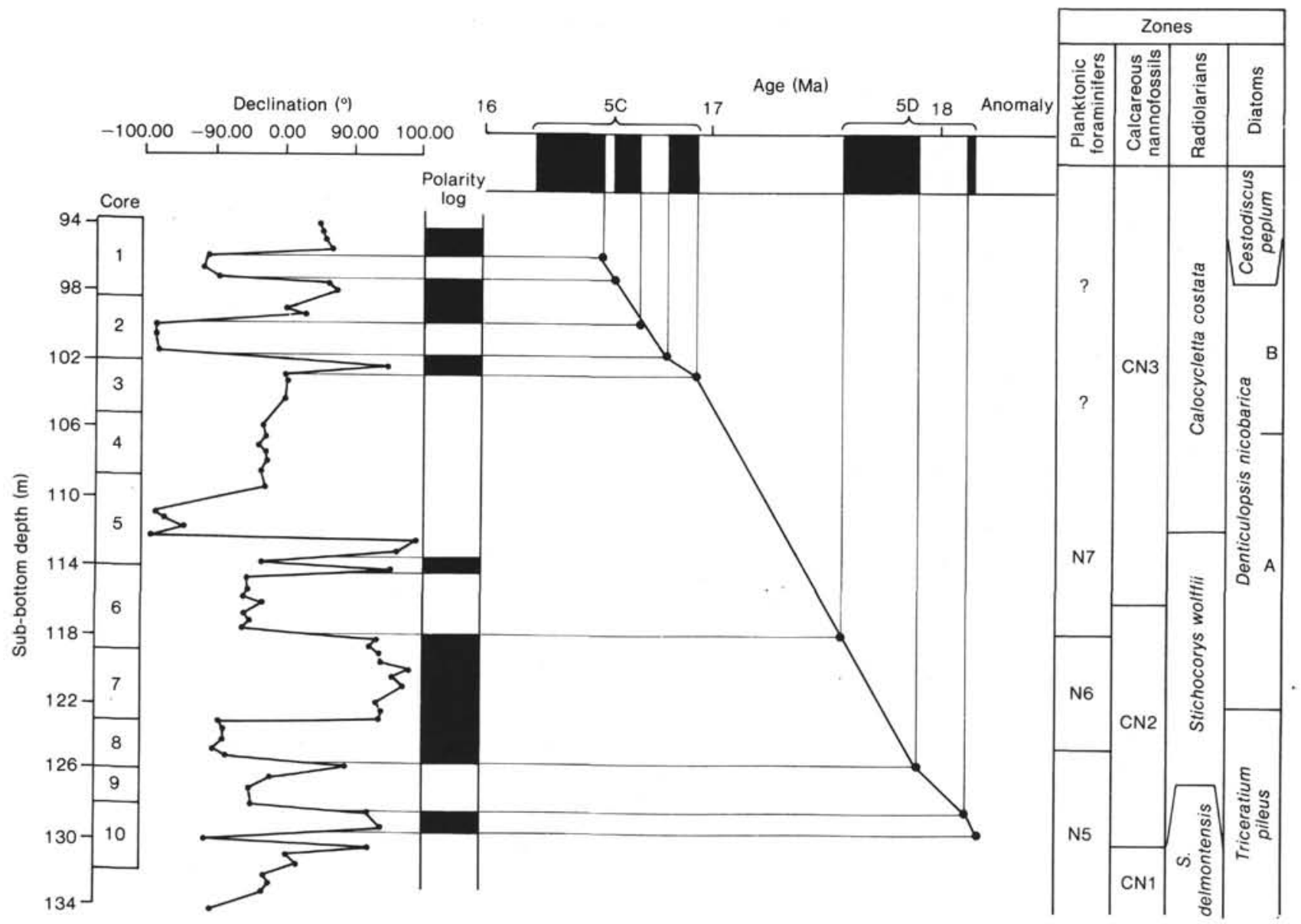

Figure 5. Suggested correlation of the polarity sequence of Weinreich and Theyer (this volume) for Cores 575A-1 through 575A-10 with the paleomagnetic time scale of Berggren et al. (in press). Planktonic foraminifer, calcareous nannofossil, and radiolarian zones are after the site chapter.

(1974) and Berggren (1981). It also is compatible with the paleomagnetic correlations (Poore et al., 1983) of planktonic foraminiferal Zone N8 and calcareous nannofossil Zones CN3 and CN4 with the upper reversed event of paleomagnetic Chron 16. In addition, the correlation of Figure 5 produces a relatively straight ageversus-depth curve for the lower Miocene of Sites 574 and 575 when coupled with younger diatom datum levels tied directly to paleomagnetics (by Burckle, 1978) and older diatom datum levels calibrated indirectly with paleomagnetics (by Barron et al., in press).

The ranges of key diatoms in Cores 1 to 10 of Hole $575 \mathrm{~A}$ are presented on Figure 6. The sequence of datums in the interval from the middle part of the Triceratium pileus Zone to the lowermost Cestodiscus peplum Zone agrees well with the sequence at Sites 574 and 575 (Table 3), and with the sequences at Sites 71, 77, and 495 (Barron, 1983). As discussed by Barron (1983), Burckle's (1978) correlations of the first occurrence of $\mathrm{An}$ nellus californicus with upper Chron 16 and of the first occurrence of Cestodiscus peplum with uppermost Chron 17 are discounted, because these datums consistently occur in the reverse order. The Annellus californicus firstoccurrence datum of Burkle (1978), however, may represent a recurrence, because the species becomes sparse to absent above its initial occurrences (Barron, 1983). The remaining diatom datum levels on Figure 6 are correlated directly with paleomagnetic stratigraphy for the first time. Occurrence data are presented, in part, on Table 4. The Thalassiosira spinosa and T. spumellaroides last-occurrence datums are regarded with some doubt, because they represent isolated sparse occurrences. The other datum levels are placed above or below continuous occurrences, although Annellus californicus, Craspedodiscus coscinodiscus $\mathrm{s}$. str., and Triceratium pileus are generally sparse.

\section{QUANTITATIVE DIATOM BIOSTRATIGRAPHY}

Quantitative diatom data for the late early Miocene to latest Miocene (17.8 to 6.3 Ma) of Sites 572, 574, and 575 are presented on Tables 4 to 7 . These data are supplemented by data from DSDP Sites 77 (within $10 \mathrm{~km}$ of Site 573) and 158 (Tables 8 to 10 ) to complete a transect from the easternmost equatorial Pacific to the central Pacific (Fig. 1). For the late early and middle Miocene, one to two samples per 100,000 -yr. span in the section were counted from Sites 158, 572, 574, and 575. For the late Miocene and for Site 77, sampling intervals average one per 200,000 to 300,000 yrs. The age-versus-depth curves (Figs. 4 and 5) were used to assign absolute ages 


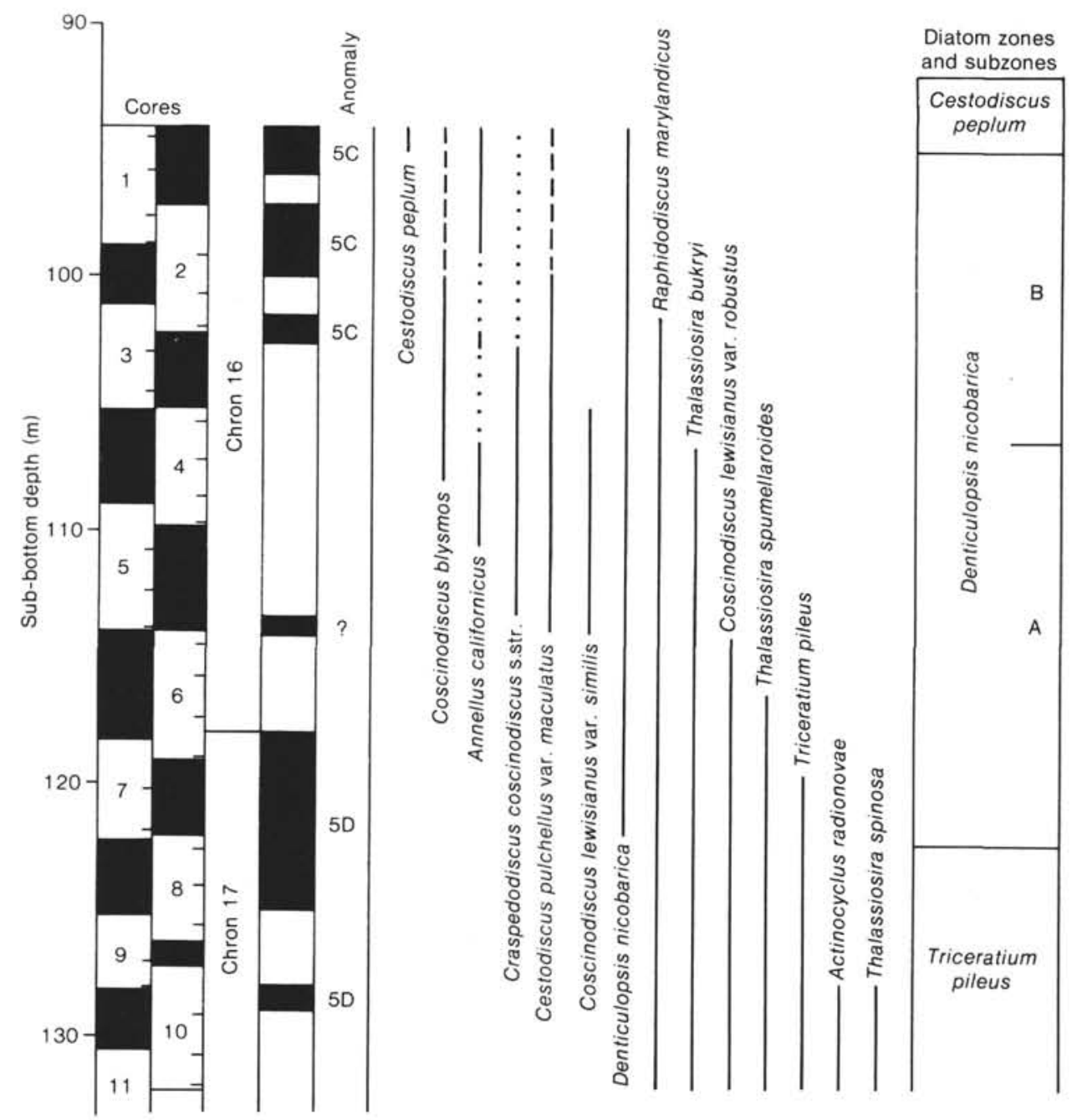

Figure 6. Correlation of diatom ranges in Cores 575A-1 through 575A-10 with paleomagnetic stratigraphy. Refer to Figure 5 and Table 3.

to the Leg 85 samples, whereas curves constructed with the same datums and time scale (Barron et al., in press) were used to assign ages to the Site 77 and Site 158 samples. These ages, therefore, are assigned solely by diatom datum level and paleomagnetic control, and they provide a framework for evaluating the abundance trends of individual diatom species and assessing their use for biostratigraphy. Where quantitative changes have been induced by abrupt region-wide changes in paleoceanography, these changes should approach isochroneity in the equatorial Pacific sections (Burckle and Trainer, 1979; Barron and Keller, 1983). In addition, quantitative data obtained from the sections can be useful in directly establishing the paleogeography of individual species during the late early Miocene to latest Miocene in the equatorial Pacific, and in determining paleoceanographic and paleoclimatic changes.

In the following section, quantitative trends of individual species will be discussed in the light of their stratigraphic value, and differences in the abundance of these species across the equatorial Pacific will be noted. Pale- oceanographic and paleoclimatic interpretations are treated in Barron (this volume). The error in assigning absolute ages to the samples from the age-versus-depth curves is believed to be as much as 100,000 yrs., so that distinctive quantitative changes occurring at two or more sites within $100,000 \mathrm{yrs}$. of each other will be treated as isochronous. It is hoped that $\mathrm{CaCO}_{3}$ and isotope stratigraphy will provide the stratigraphic resolution necessary to test the isochroneity of these changes.

Actinocyclus ehrenbergii has two brief abundance spikes in the middle Miocene, where abundance values double to triple. One event at about $13.2 \mathrm{Ma}$ is apparent at Site 574 (Table 5) and Site 572 (Table 6), where A. ehrenbergii increases to $10 \%$ of the assemblage. This event seems more abrupt at Site 572, so it may be more distinctive in the eastern equatorial Pacific. The event was apparently missed by the broader sampling interval at Site 77 , and it predates the Site 158 sedimentary record. The second $A$. ehrenbergii abundance spike at about $12.1 \mathrm{Ma}$ is recognizable at Sites $547,77,572$, and 158 (Tables 5, 6, 8, and 9). Again, abundance values reach 8 
Table 8. Percent planktonic diatoms in Cores 17 to 28 of Hole 77B.

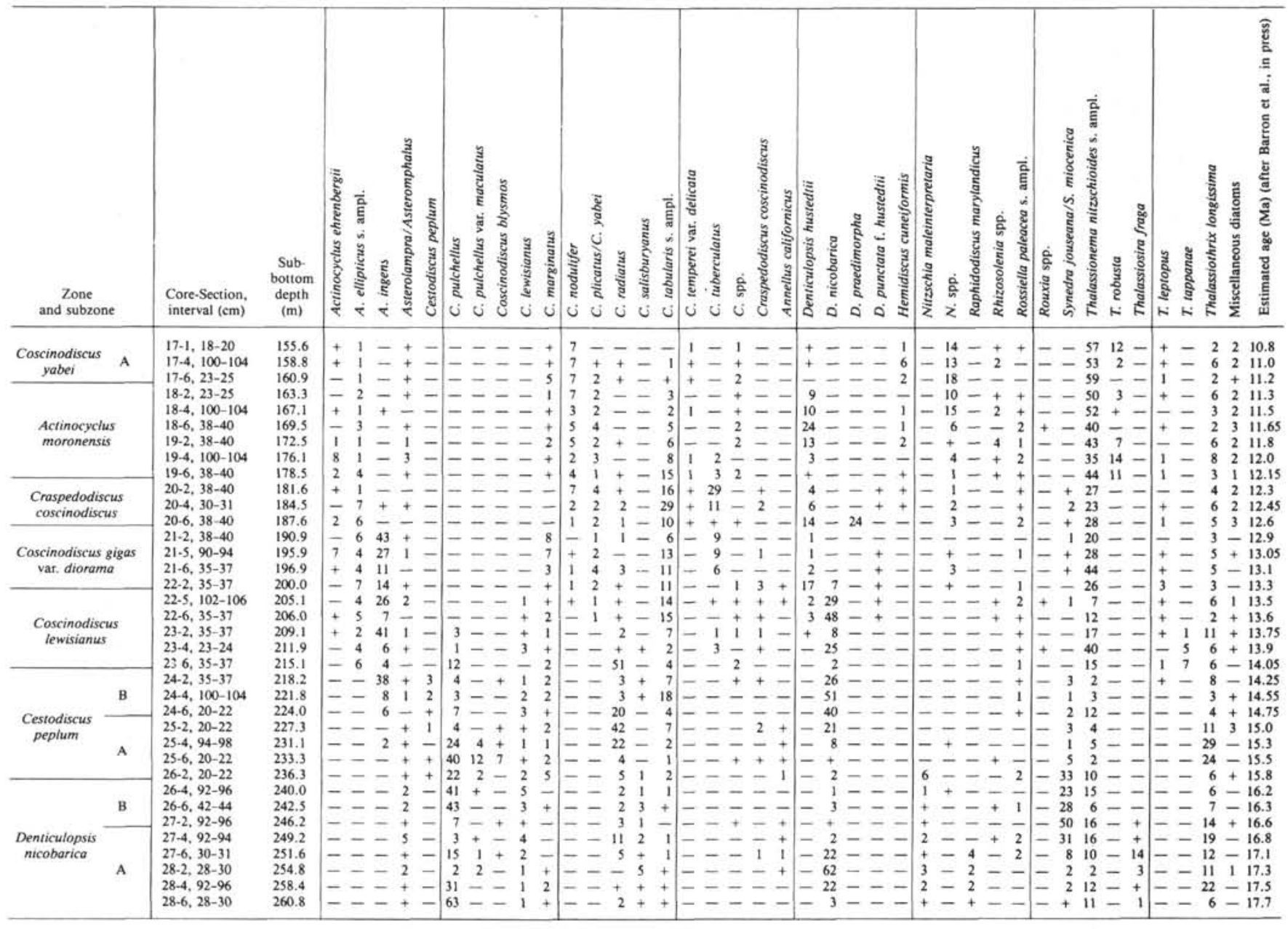

Note: + means $<1 \%$ or encountered after the count; - means not encountered. 300 specimens were counted.

to $10 \%$, with the exception of Site 158 , where values reach $6 \%$. Overall, $A$. ehrenbergii seems slightly more abundant in the west than in the east.

Actinocyclus ellipticus s. ampl. shows no distinctive trends for biostratigraphy, although it is generally most common in the Coscinodiscus gigas var. diorama Zone $(13.5$ to $12.8 \mathrm{Ma})$ at all sites, and exhibits a slight preference for the western sites.

Actinocyclus ingens was introduced to the tropics from middle latitudes (Barron, 1983), and it was excluded from the tropics before its extinction at higher latitudes (Burckle, 1978). It is generally present in low numbers $(<10 \%)$ in middle Miocene sediment, but it reaches values of 20 to $50 \%$ in isolated samples from the middle Miocene of Sites 574, 77, 572, and 158 (Tables 5, 6, 8, and 9). Some of these events appear to be roughly isochronous (about $50 \%$ at $14.8 \mathrm{Ma}$, Sites 574 and 572; about 25 to $30 \%$ at $14.5 \mathrm{Ma}$, Sites 574 and 572 ; and about $30 \%$ at $13.5 \mathrm{Ma}$, Sites 77 and 574). Other isolated abundance spikes, especially those at Site 77, show little comparison in site-to-site correlations. Actinocyclus ingens is a robust diatom that would be concentrated by dissolution of other less resistant diatoms. Dissolution, however, is not solely responsible for the abundance spikes of $A$. ingens, because other resistant diatoms such as Cestodiscus pulchellus and Coscinodiscus radiatus are not concentrated in the same samples and less resistant species (Denticulopsis spp.) are not selectively removed from the same samples. Core 77B-21 (13.1 to $12.9 \mathrm{Ma})$ and Sample 158-34-1, 50-51 cm (12.65 Ma) do, however, appear to have dissolved assemblages along with increased numbers of $A$. ingens.

Quantitative trends for Cestodiscus pulchellus and C. pulchellus var. maculatus are shown on Figure 7. Sites 575 and 77 show good comparison in abundance trends of $C$. pulchellus s. ampl. between 18 and $16 \mathrm{Ma}$, with abundant $C$. pulchellus s. ampl. at $17.5 \mathrm{Ma}$ declining sharply by one half or more (to 10 to $20 \%$ ) by $17.3 \mathrm{Ma}$. Cestodiscus pulchellus s. ampl. increases again at about 16.6 Ma to values around $40 \%$ of the assemblage at Sites 575 and 77 , but it declines abruptly at 15.4 to 15.2 Ma to values that remain low $(<10 \%)$ for the remainder of its range. Where they can be compared, Sites 575 and 77 have similar abundances of $C$. pulchellus s. ampl., but Site $\mathbf{5 7 4}$ has abundances roughly half of those sites between 16.6 and $15.3 \mathrm{Ma}$. These lower values at Site 574 possibly reflect the site's position at 16.6 to 15.3 Ma: just south of the equator, within the area corre- 


\section{J. A. BARRON}

Table 9. Percent planktonic diatoms in Cores 22 to 34 of Hole 158.

\begin{tabular}{|c|c|c|c|c|c|c|c|c|c|c|c|c|c|c|c|c|c|c|c|c|c|c|c|c|c|c|c|c|c|c|c|c|}
\hline $\begin{array}{c}\text { Zone } \\
\text { and subzone }\end{array}$ & $\begin{array}{l}\text { Core-Section, } \\
\text { interval }(\mathrm{cm})\end{array}$ & $\begin{array}{l}\text { Sub- } \\
\text { bottom } \\
\text { depth } \\
\text { (m) }\end{array}$ & 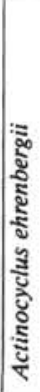 & 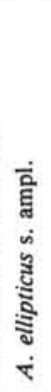 & 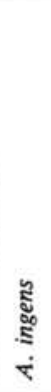 & 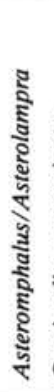 & 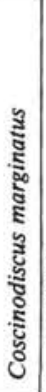 & ¿ัँ & 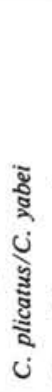 & 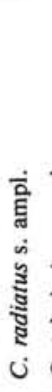 & 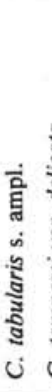 & 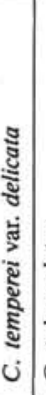 & 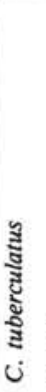 & 客 & 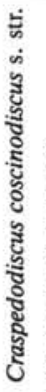 & 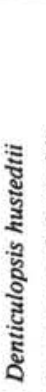 & 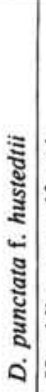 & 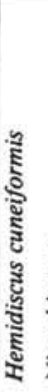 & 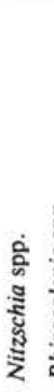 & 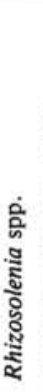 & 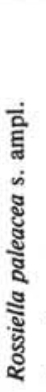 & 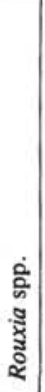 & & 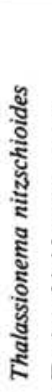 & 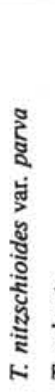 & 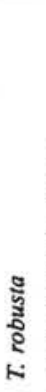 & 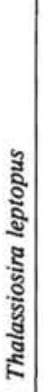 & 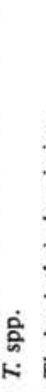 & 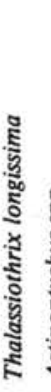 & & 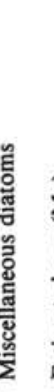 & 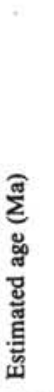 \\
\hline \multirow{7}{*}{$\begin{array}{c}\text { Coscinodiscus } \\
\text { yabei, } \\
\text { Subzone A }\end{array}$} & $22-2,30-32$ & 190.8 & - & 6 & - & 1 & 1 & 2 & 4 & 6 & 4 & 1 & - & - & - & & - & + & 7 & + & - & - & - & 38 & 6 & - & - & & $18-$ & - & $\begin{array}{ll}3 & 10\end{array}$ & 0.8 \\
\hline & $-6,30-32$ & 196.8 & - & 4 & - & 1 & + & 4 & 8 & 4 & 9 & 1 & - & + & - & 1. & - & 3 & 5 & - & + & - & - & 18 & 6. & - & 4 & 12 & $26-$ & - & $4 \quad 10$ & 0.9 \\
\hline & $23-2,30-32$ & 199.8 & - & 2 & - & + & + & 7 & + & 3 & 3 & - & - & 1. & - & + & - & 13 & 3 & 1 & - & - & - & 28 & 19. & - & 2 & + & $15-$ & - & 210 & 0.95 \\
\hline & $23-5,30-32$ & 204.3 & - & + & - & - & 7 & 9 & 2 & 1 & 1 & + & - & 1. & - & 3. & - & 1 & 15 & 2 & - & - & - & 21 & 17. & - & 1 & + & $19-$ & - & +11 & 1.05 \\
\hline & $24-1,108-110$ & 208.1 & - & + & - & + & - & 2 & - & + & 1 & + & - & - & - & 17. & - & 2 & 2 & - & - & - & - & 44 & 18 & - & - & + & $9-$ & - & 111 & 1.1 \\
\hline & $24-3,30-32$ & 210.3 & - & + & + & - & - & 1 & 2 & + & + & + & - & + & - & 8 & - & 2 & 1 & 1 & - & - & - & 39 & 27. & - & + & -1 & $15-$ & - & +11 & 1.15 \\
\hline & $25-2,30-32$ & 217.8 & - & + & - & - & - & 3 & + & + & $2-$ & -1 & - & - & - & 9 . & - & + & + & + & + & - & - & 26 & 28 & 7 & + & 3 & 16 & + & +11 & 1.25 \\
\hline \multirow{11}{*}{$\begin{array}{l}\text { Actinocyclus } \\
\text { moronensis }\end{array}$} & $25-6,30-32$ & 223.8 & - & 2 & - & - & - & 3 & 7 & + & 6 & -1. & - & 1. & - & 10 & - & 2 & - & - & + & - & - & 24 & 13 & 5 & + & & 22. & + & 211 & 1.35 \\
\hline & $26-2,30-32$ & 226.8 & - & 3 & - & + & - & 3 & + & - & +- & $-1-$ & - & + & - & 50 & - & + & + & + & 1 & - & - & 9 & 11 & - & + & & $14-$ & - & 311 & 1.4 \\
\hline & $26-6,30-32$ & 232.8 & + & 3 & - & - & - & 4 & 1 & - & 1 & -1. & - & - & -1 & 35 . & - & + & 1 & - & + & - & - & 9 & 10. & - & 1 & & $24-$ & - & 111 & \\
\hline & $27-2,30-32$ & 235.8 & - & 1 & - & + & -1 & 3 & + & + & + & + & - & + & -3 & 22 & - & + & - & - & + & - & - & 42 & 20. & - & - & & 9. & - & -11 & 1.55 \\
\hline & $27-6,30-32$ & 241.8 & - & - & - & - & - & 2 & 1 & - & 1 & + & - & - & - & 70 & - & + & + & - & - & - & + & 7 & 7. & - & - & & $11-$ & - & 111 & 1.65 \\
\hline & $28-1,30-32$ & 243.3 & - & 3 & - & + & -1 & 1 & 3 & 1 & 3 & + & 1 & + & - & 61 & - & - & + & + & - & - & - & 8 & 9. & - & 1 & & 10. & - & -11 & 1.7 \\
\hline & $28-3,30-32$ & 246.3 & - & 1 & - & - & + & 2 & 2 & - & 2 & 1 & + & + & - & 68 & - & + & 1 & + & + & - & - & 5 & 9 & + & - & - & $6-$ & - & +11 & 1.75 \\
\hline & $29-3,30-32$ & 255.3 & - & 2 & - & + & - & + & 3 & - & 3 & + & - & + & - & 61. & - & + & 1 & + & 1 & + & - & 1 & 9 & 2 & + & & $11-$ & - & 211 & 1.95 \\
\hline & $-1,30-32$ & 261.3 & 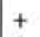 & 1 & - & - & 4 & 2 & 5 & 13 & 5 & 1 & 1 & 1. & - & 1. & - & 1 & 2. & - & - & - & - & 34 & 11 & 1 & 1 & & $15-$ & - & $1 \quad 12$ & 2.05 \\
\hline & $30-5,30-32$ & 267.3 & 2 & 3 & - & + & 3 & 8 & 2 & + & 2 & + & 18 & 1. & - & 2 & + & 1 & + & - & + & - & 1 & 122 & 25 & 7 & + & - & 3 & - & 212 & 2.15 \\
\hline & & 270. & 6 & 2 & - & 1 & 3 & 3 & 3 & 2 & 3 & 2 & 4 & 2 & - & 4 & 2 & + & 2 & + & 1 & + & & 22 & 15 & 3 & - & & $11-$ & - & $7 \quad 12$ & 2.2 \\
\hline \multirow{4}{*}{$\begin{array}{l}\text { Craspedodiscus } \\
\text { coscinodiscus }\end{array}$} & $32-2,30-32$ & 280.8 & + & 3 & + & - & + & 5 & 3 & - & 3 & - & 17 & + & + & 5 & + & - & 2 & - & 2 & - & + & 9 & 42 & - & + & - & 7 & - & +12 & 2.35 \\
\hline & $32-4,30-32$ & 283.8 & + & 1 & + & + & - & 4 & 4 & + & 7 & + & 13 & 1 & 1 & 7 & + & + & + & - & + & + & - & 112 & 29 & + & - & -1 & $13-$ & - & $\begin{array}{ll}5 & 12\end{array}$ & 2.4 \\
\hline & $33-2,30-32$ & 288.3 & 4 & + & - & + & + & 1 & 3 & 1 & 7 & 2 & 9 & 1 & + & 2 & + & - & + & + & - & - & + & 172 & 23. & - & - & -1 & 18. & + & 212 & 2.5 \\
\hline & $34-1,50-51^{\mathrm{a}}$ & 296.5 & 2 & 15 & 23 & 1 & 7 & - & 4 & 1 & 1 & 1 & 10 & 1. & - & 1 & 1 & - & 1. & - & - & - & 1 & 17 & 5 & - & - & -1 & $11-$ & - & 112 & 2.65 \\
\hline
\end{tabular}

Note: + means $<1 \%$ or encountered after the count; - means not encountered. 300 specimens were counted.

a 200 specimens were counted.

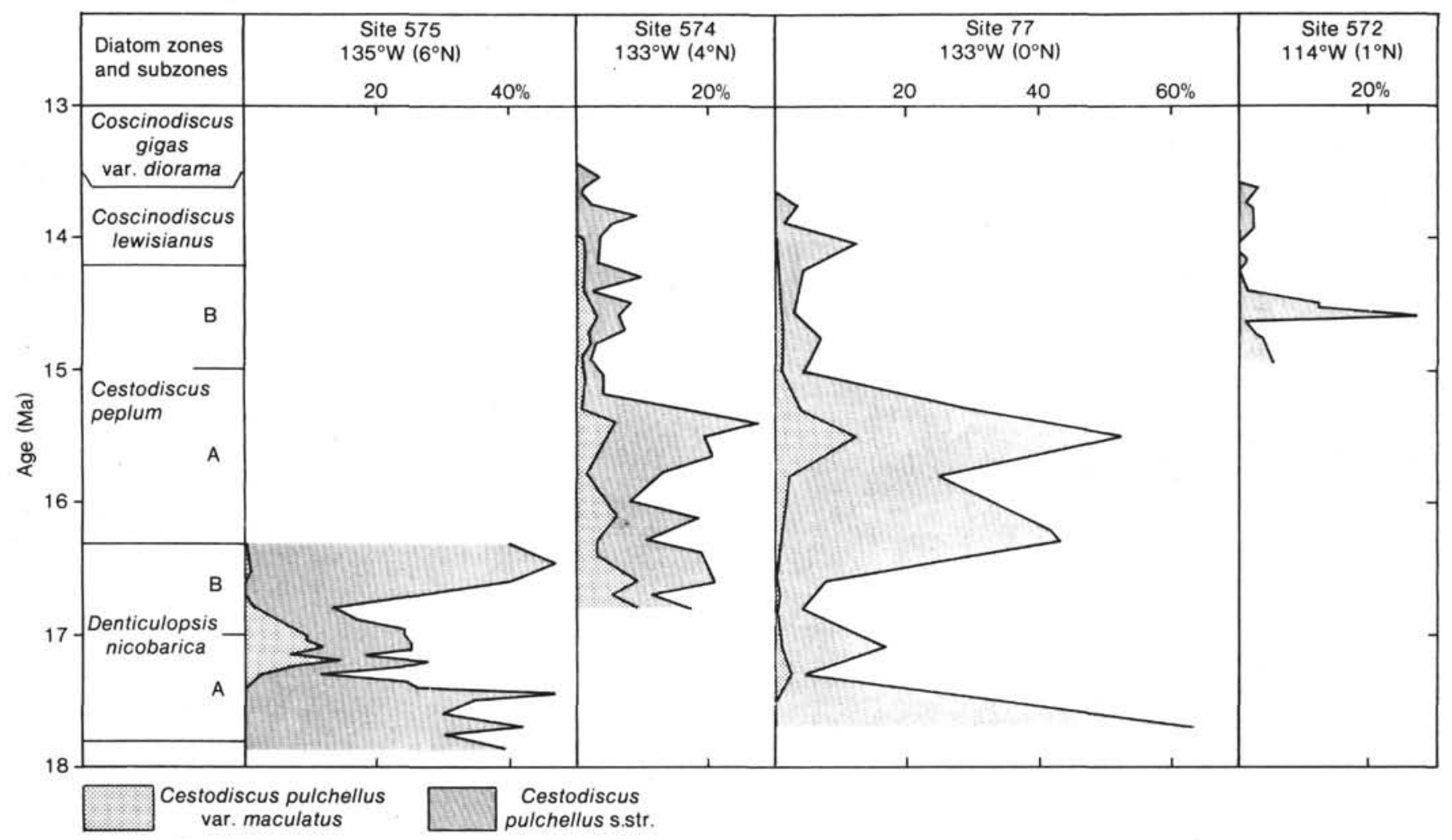

Figure 7. Relative abundance of Cestodiscus pulchellus and C. pulchellus var. maculatus at DSDP Sites 575, 574, 77 , and 572 (after $17.8 \mathrm{Ma}$ ), plotted against age. Refer to Tables $4,5,6$, and 8 . 
sponding to maximum primary productivity and opal accumulation in the Holocene ocean (van Andel et al., 1975). Cestodiscus pulchellus var. maculatus typically makes up less than half of the $C$. pulchellus s. ampl. populations, except between 17.2 and $17.0 \mathrm{Ma}$ at Site 575 , where it is roughly equivalent in numbers with the type form.

Quantitative trends of Coscinodiscus nodulifer s. ampl. across the equatorial Pacific are shown on Figure 8. C. nodulifer is typically less than $10 \%$ of the assemblage for the middle Miocene and most of the late Miocene, and it shows no definitive abundance peaks that can be correlated between the four sites. At about $8 \mathrm{Ma}$, however, $C$. nodulifer approaches values of $20 \%$ at easternmost Site 158, and it remains at comparable values through 6.2 Ma. During this same interval (8.0 to 6.2 $\mathrm{Ma}$ ), values of $C$. nodulifer at the other sites are gener- ally half of those at Site 158. L. H. Burckle (pers. comm., 1983) relates $C$. nodulifer to equatorial upwelling in the modern Pacific Ocean, so it is possible that the greater values of $C$. nodulifer after $8 \mathrm{Ma}$ at easternmost Site 158 reflect enhanced upwelling there with respect to the more western sites.

The quantitative trends of Coscinodiscus radiatus s. ampl. before 14.2 Ma are shown on Figure 9. Late early Miocene and early middle Miocene forms tabulated as $C$. radiatus $\mathrm{s}$. ampl. may include some forms allied with C. blysmos, which differs from $C$. radiatus only by the presence of a central indentation. The $C$. radiatus morphology is relatively simple, and it is entirely possible that different species can achieve it independently. The biostratigraphically most definitive trends in $C$. radiatus abundance include abundance spikes ( $20 \%$ or more) at 17.0 to $16.7 \mathrm{Ma}$ at Sites 575 and 574 (not as pronounced

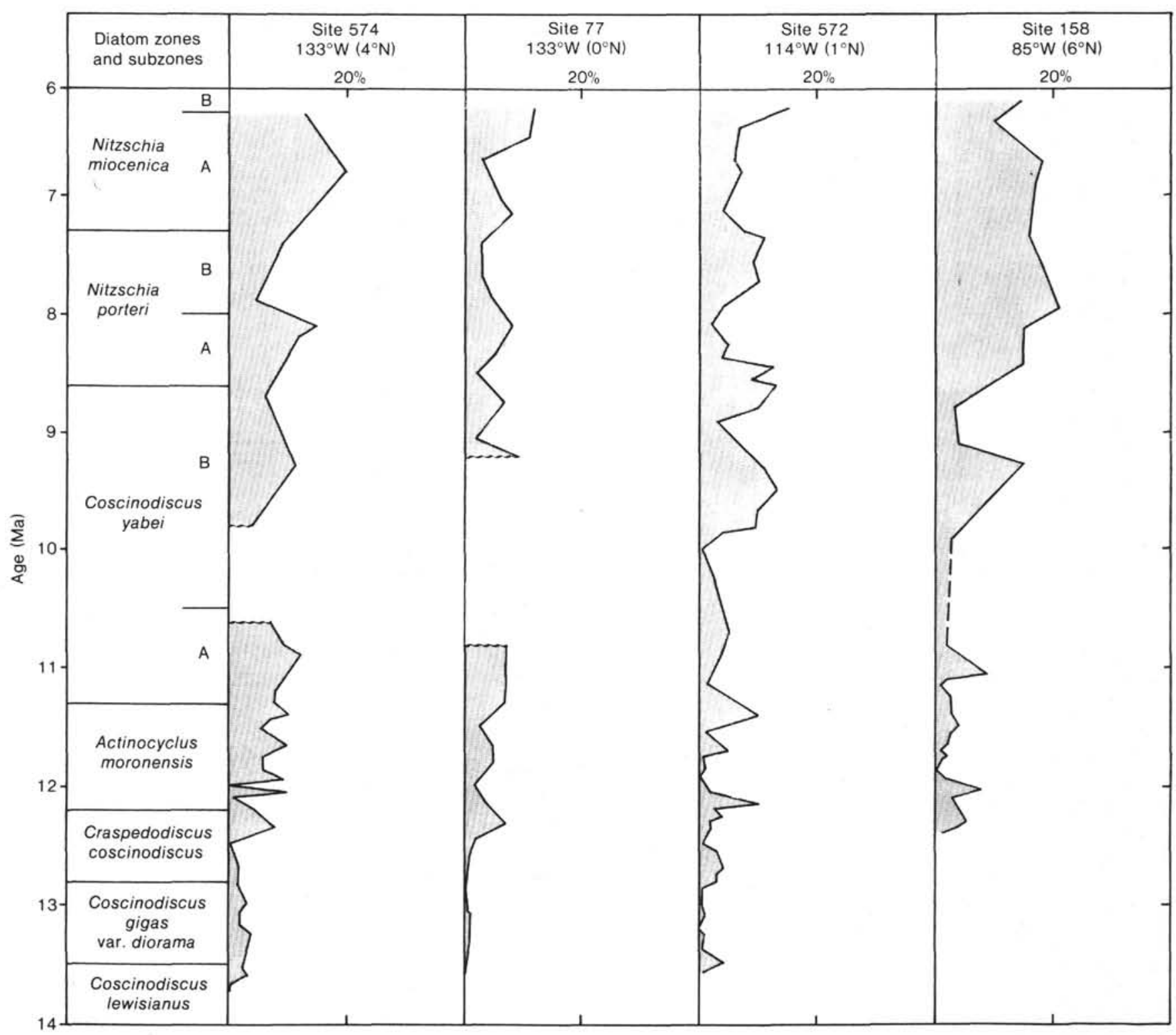

Figure 8. Relative abundance of Coscinodiscus nodulifer s. ampl. (before 6.1 Ma) at DSDP Sites 574, 77, 572, and 158, plotted against age. Refer to Tables 5 to 10 . 


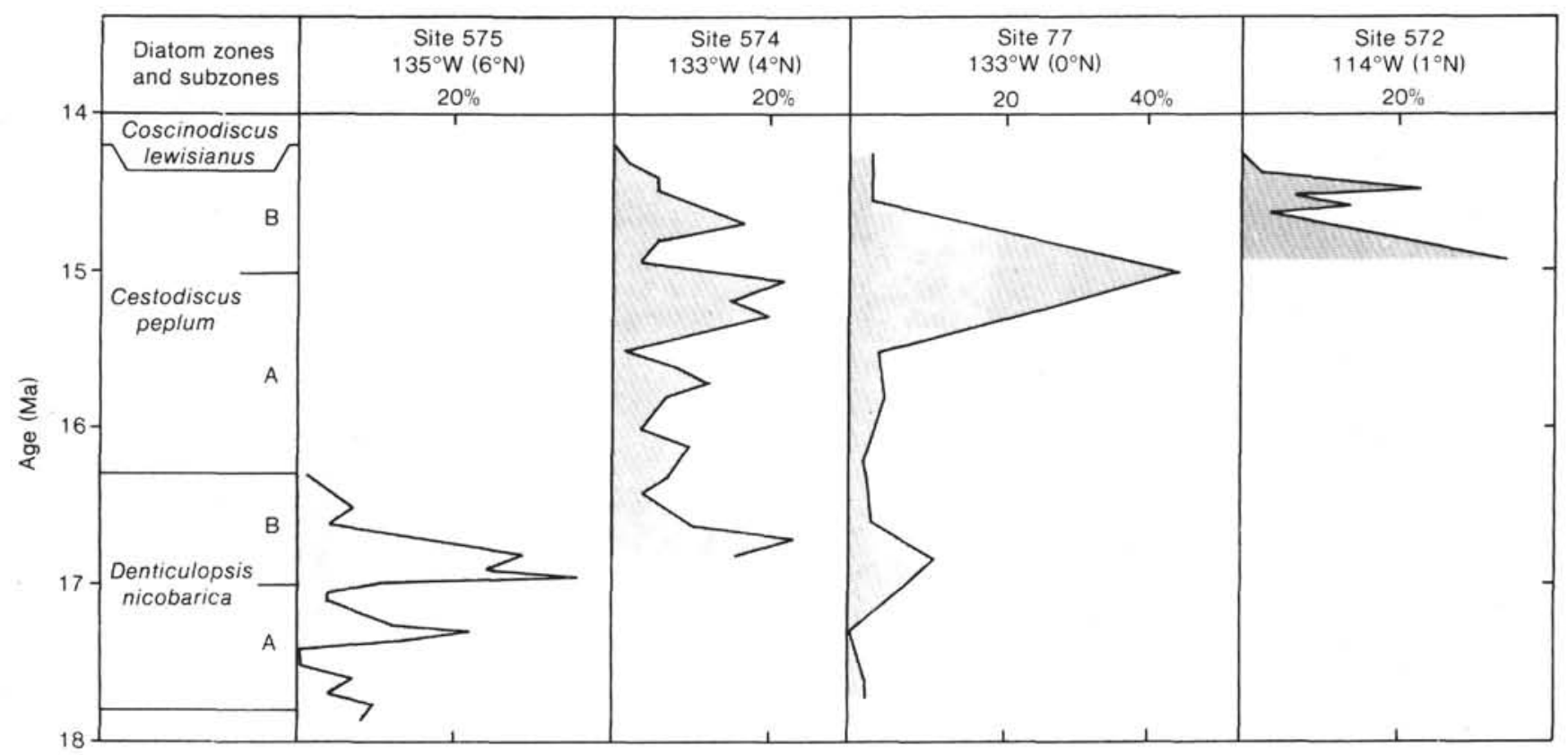

Figure 9. Relative abundance of Coscinodiscus radiatus s. ampl. (between 17.8 and $14.2 \mathrm{Ma}$ ) at DSDP Sites 575, 574, 77, and 572, plotted against age. Refer to Tables $4,5,6$, and 8 .

at Site 77) and at about 15.3 to $14.7 \mathrm{Ma}$ at Sites 574,77 , and 572. Coscinodiscus radiatus is robust and relatively resistant to dissolution, but other less resistant diatoms (including Denticulopsis spp.) do not appear to have been selectively removed in samples containing common $C$. radiatus, and dissolution alone cannot explain the abundance spikes. Coscinodiscus radiatus s. ampl. shows no noticeable differences in its abundance at the various sites, although the abundance spikes (e.g., 16.8 and 15.0 Ma) at Site 574 are typically one half the size of the corresponding spikes at Sites 575 and 77 . It should also be pointed out that between 18 and $14.5 \mathrm{Ma}$ there appears to be an antithetical relationship between the abundance peaks for Coscinodiscus radiatus and Cestodiscus pulchellus (compare Figs. 7 and 9).

Coscinodiscus tabularis s. ampl. generally is most common (10\% or more) between 13.5 and $12.5 \mathrm{Ma}$ at Sites 574,77 , and 572 , although it is also typically common between 14.6 and $13.7 \mathrm{Ma}$ at Site 574 . The species appears to show a slight preference for the central Pacific after $12.5 \mathrm{Ma}$, as compared with easternmost Pacific Site 158.

Coscinodiscus tuberculatus remains generally sparse to few (10\% or less) throughout much of its range (14.0 to $12.0 \mathrm{Ma}$ ), but it abruptly increases in abundance to 20 to $36 \%$ at 12.4 to $12.2 \mathrm{Ma}$, immediately before its last consistent occurrence $(12.0 \mathrm{Ma})$. Abundance values are somewhat greater at the western sites ( 574 and 77 ) and least of all at easternmost Site 158. At all four sites (574, 77,572 , and 158), C. tuberculatus declines sharply in abundance to values of 1 to $2 \%$ between 12.2 and $12.1 \mathrm{Ma}$.

Figure 10 gives the quantitative trends of Denticulopsis hustedtii across the equatorial Pacific. As discussed by Burckle (1978) and Barron (in press), this high- to middle-latitude species was introduced into the tropics in the middle middle Miocene and was excluded from the tropics by the early late Miocene, well before its extinction at higher latitudes in the early Pliocene. After a brief incursion into low latitudes at about $14.2 \mathrm{Ma}$ (Sites 572 and 574), D. hustedtii became established in the region by about $13.9 \mathrm{Ma}$. Thereafter, $D$. hustedtii persisted at relatively low abundances ( 5 to $10 \%$ at Sites 574 and $77 ; 10$ to $15 \%$ at Site 572 ) until about $12.0 \mathrm{Ma}$, when the abundance increased dramatically to 50 to $60 \%$ at all sites except Site 77. The lack of such a dramatic increase at Site 77 either reflects the greater sample spacing there or may indicate a hiatus (see greatly reduced sediment accumulation rate between 12.0 and $11.5 \mathrm{Ma}$ at nearby Site 573, Fig. 2). At about $11.5 \mathrm{Ma}, D$. hustedtii declines just as abruptly to values of $10 \%$. By $11.1 \mathrm{Ma}$ it has dropped to $2 \%$ or less, and by $10.5 \mathrm{Ma}$ it has disappeared from the tropical Pacific. Denticulopsis hustedtii is more abundant at the eastern sites (Sites 572 and 159) even during its abundance spike (12.0 to 11.5 $\mathrm{Ma}$ ), where only two single points at Site 574 exceed $50 \%$ abundance and values at 11.9 to $11.8 \mathrm{Ma}$ drop abruptly but briefly to below $10 \%$.

Denticulopsis nicobarica exhibits a curiously bimodal distribution in its range (17.8 to $13.2 \mathrm{Ma})$ in the equatorial Pacific (Fig. 11). It is generally common to abundant $(>20 \%)$ between 17.5 and $17.1 \mathrm{Ma}$, but drops off sharply in abundance to values of $5 \%$ or less for the interval from 16.9 to $15.7 \mathrm{Ma}$. Between 15.5 and 15.0 $\mathrm{Ma}, D$. nicobarica increases gradually in abundance to 30 to $50 \%$, and it remains abundant through $13.6 \mathrm{Ma}$. Thereafter, $D$. nicobarica decreases abruptly to values of $5 \%$ or less by $13.4 \mathrm{Ma}$. Undoubtedly, dissolution and/ or winnowing of the small, relatively fragile $D$. nicobarica tests are responsible for much of the decline of D. nicobarica between 16.9 and $15.7 \mathrm{Ma}$, because other small delicate species (Nitzschia spp., Thalassionema spp., 


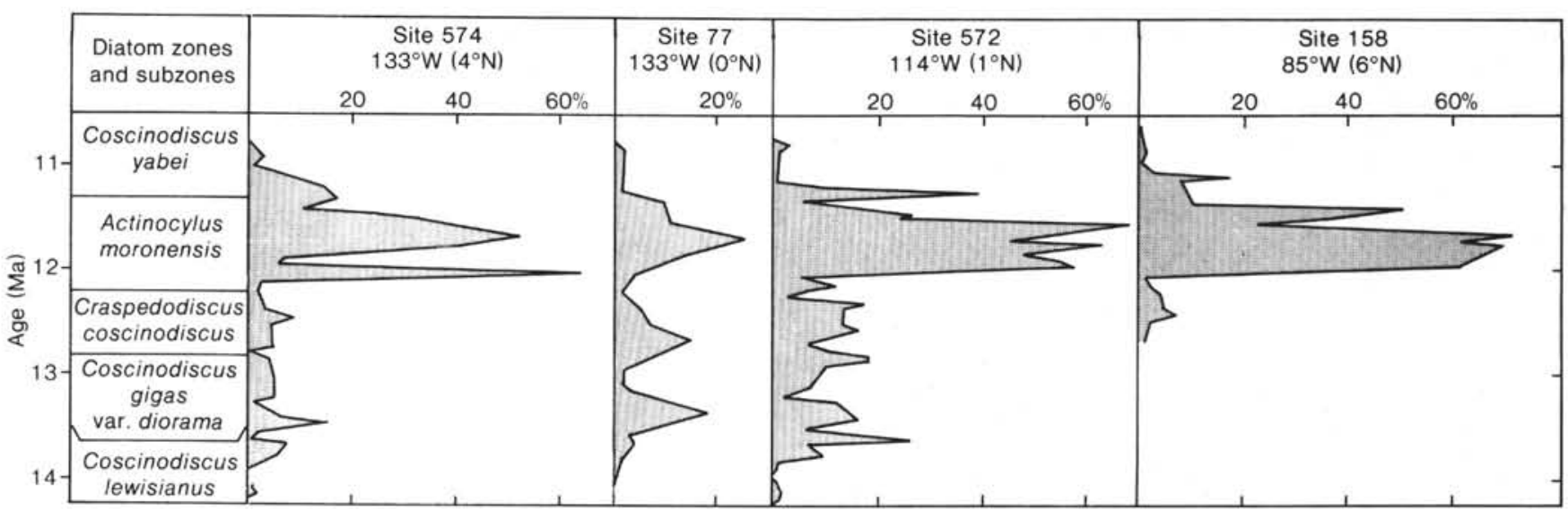

Figure 10. Relative abundance of Denticulopsis hustedtii at DSDP Sites 574, 77, 572, and 158, plotted against age. Refer to Tables 5, 6, 8, and 9.

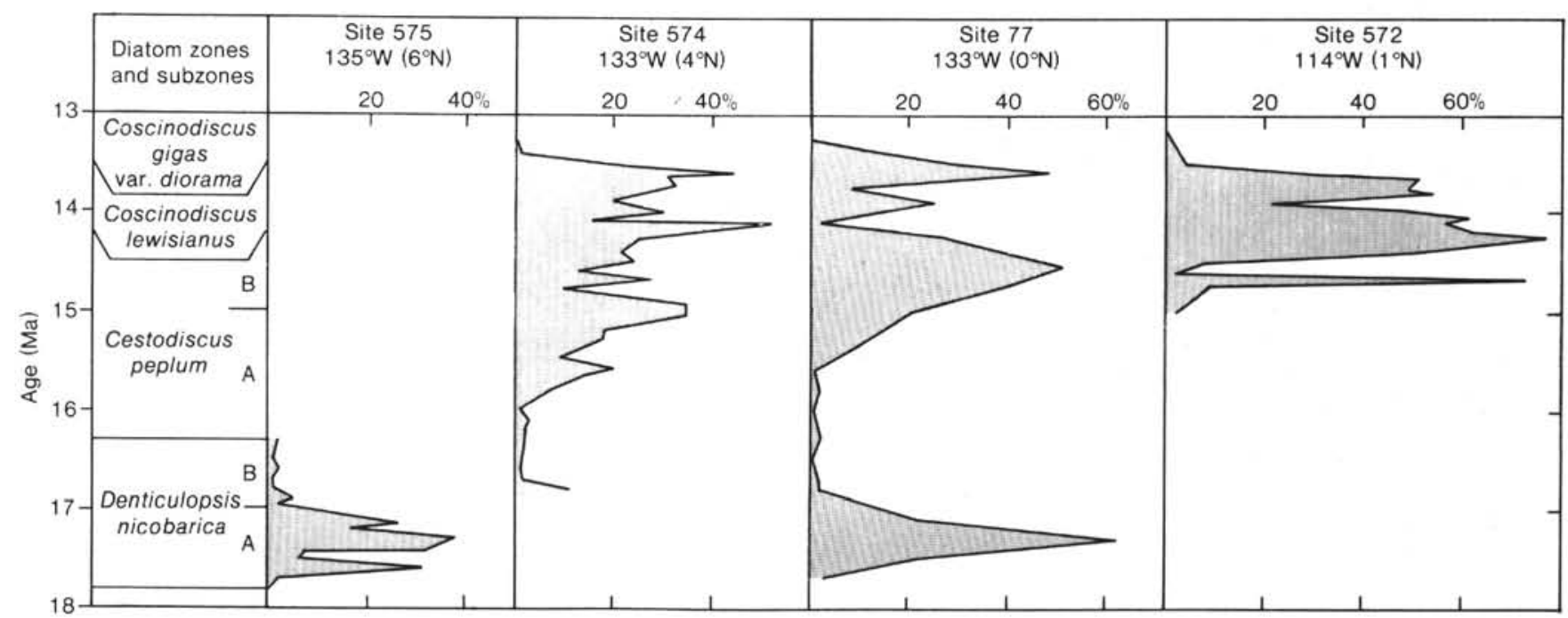

Figure 11. Relative abundance of Denticulopsis nicobarica at DSDP Sites 575, 574, 77, and 572, plotted against age. Refer to Tables 4, 5, 6, and 8.

and Thalassiothrix spp.) are also sparse in that interval. This decline in $D$. nicobarica abundance corresponds to the interval of warmest isotopic temperatures of the Miocene (Savin et al., 1981) and may reflect decreased opal productivity caused by decreased equatorial upwelling (Barron, this volume).

Denticulopsis praedimorpha is a high- to middle-latitude diatom which had a brief incursion into the tropics between 12.9 and $12.6 \mathrm{Ma}$ (Tables 5, 6, and 8). The most pronounced incursion is at about $12.6 \mathrm{Ma}$; values of $20 \%$ or more are encountered at the corresponding level at Sites 574 and 77 . This horizon was not observed at eastern Sites 572 and 158 , possibly because of its brevity and the sampling interval. Alternatively, concentration of $D$. nicobarica at this horizon at the western sites may reflect transportation of the species from higher southern latitudes by bottom waters, because hiatus NH3 of Keller and Barron (1983) was more dominant in the western Pacific than in the eastern Pacific at that time.

Hemidiscus cuneiformis is generally rare throughout its early range, but it triples in abundance (to about
$10 \%$ ) at about $11.0 \mathrm{Ma}$ at Sites 574, 77, and 158. Abundance values are typically greatest at easternmost Site 158, especially in the late Miocene (Tables 7 and 10).

Figure 12 shows the abundance trends for Nitzschia porteri sensu Burckle (1972) and $N$. miocenica between 10 and 6.2 Ma. (N. porteri was not separated from other Nitzschia species below the 10-Ma level.) The record at Site 572 indicates an abundance spike ( $40 \%$ or more) for $N$. porteri between 10.3 and $9.8 \mathrm{Ma}$. This interval is removed by hiatuses at Sites 574 and 77 (Fig. 4 and Barron et al., in press) and is greatly compressed at Site 158 (Keller et al., 1982); but the Site 574 and Site 158 curves both show a decline in abundance of $N$. porteri from $9.8 \mathrm{Ma}(20$ to $30 \%)$ to $9.3 \mathrm{Ma}$ (4 to $12 \%$ ). The $N$. porteri curves between 9 and 7 . Ma show little correlation between the sites, possibly reflecting the relatively broad (200,000 to 300,000 yrs.) sampling interval; $N$. porteri appears to be slightly more common at the western sites in this interval. From 7.4 to $6.8 \mathrm{Ma}, N$. porteri declines in abundance as $N$. miocenica develops and expands, reflecting the evolutionary transition between the two species proposed by Burckle (1972). N. miocenica also seems 
Table 10. Percent planktonic diatoms in Sample 158-15-6, 30-32 cm and Cores 16 to 21 of Hole 158 and in Cores 12 to 16 of Hole $77 \mathrm{~B}$.

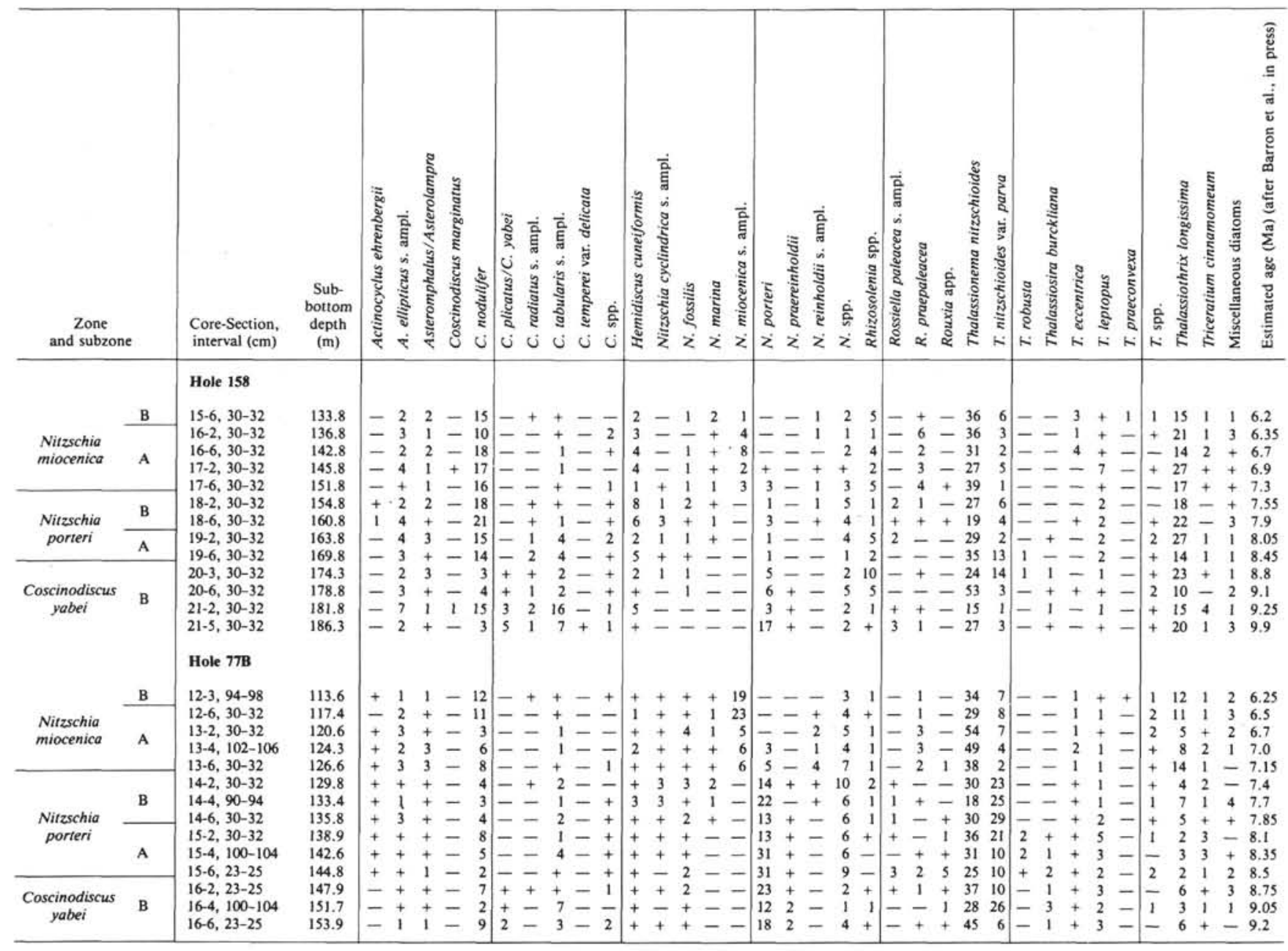

Note: + means $<1 \%$ or encountered after the count; - means not encountered, 300 specimens were counted.

to prefer the western sites (574 and 77) and central site (572) over the easternmost site (158).

Quantitative trends for Synedra jouseana are shown on Figure 13. The prominent abundance spikes at 16.6 and $15.8 \mathrm{Ma}$, where $S$. jouseana increases to $30 \%$ or more of the assemblage, are the most noticeable features of the $S$. jouseana curves. The interval of common $(\geq 20 \%)$ Synedra jouseana (16.8 to $15.7 \mathrm{Ma}$ ) coincides precisely with the interval of sparse Denticulopsis nicobarica (Fig. 11) in the latest early Miocene. After about $15.3 \mathrm{Ma}, S$. jouseana is typically sparse ( $5 \%$ or less) at all sites. Early middle Miocene abundance values are greatest at Site 77, the site farthest from the equator (about $5^{\circ} \mathrm{S}$ ) at that time.

Thalassionema nitzschioides becomes a dominant equatorial Pacific diatom in the late middle Miocene between 14.2 and $12.2 \mathrm{Ma}$, where abundance values increase from about $10 \%$ to $40-50 \%$ (Fig. 14). Close sampling intervals (100,000 yrs. or less) at Sites 572 and 574 reveal considerable variability in T. nitzschioides abundance during the late middle Miocene, so that individual abundance spikes are difficult to correlate. There is some suggestion, however, that abundance peaks at about 14.0 Ma and 13.2 Ma, and a generalized abundant interval between 12.4 and $11.9 \mathrm{Ma}$, are correlative. Between about 11.2 and $11.0 \mathrm{Ma}, T$. nitzschioides reaches its greatest numbers (60 to $70 \%$ ) for the Miocene interval investigated (18.2 to $6.2 \mathrm{Ma}$ ) at all sites (possibly earlier at Site 77). Middle Miocene assemblages are dominated by shorter forms of $T$. nitzschioides (length-to-width ratios $<3)(=T$. nitzschioides var. parva $\mathrm{s}$. ampl.). Longer forms (length-to-width ratios $\geq 3$ ) (= T. nitzschioides s. str.) are more important in the late Miocene. Sites 574,77 , and 572 all show a generalized abundance peak for T. nitzschioides var. parva s. ampl. between 8.2 and 7.3 Ma, but Site 158 shows no such peak. Other late Miocene trends in T. nitzschioides are difficult to correlate, which may again reflect high variability and relatively broad sampling intervals.

Thalassionema robusta shows a minor abundance peak between 12.15 and $12.0 \mathrm{Ma}$ at all sites (Tables 5, 6, 8, and 9), with values at the western sites (574 and 77) slightly higher than those at the eastern sites (572 and 158). 


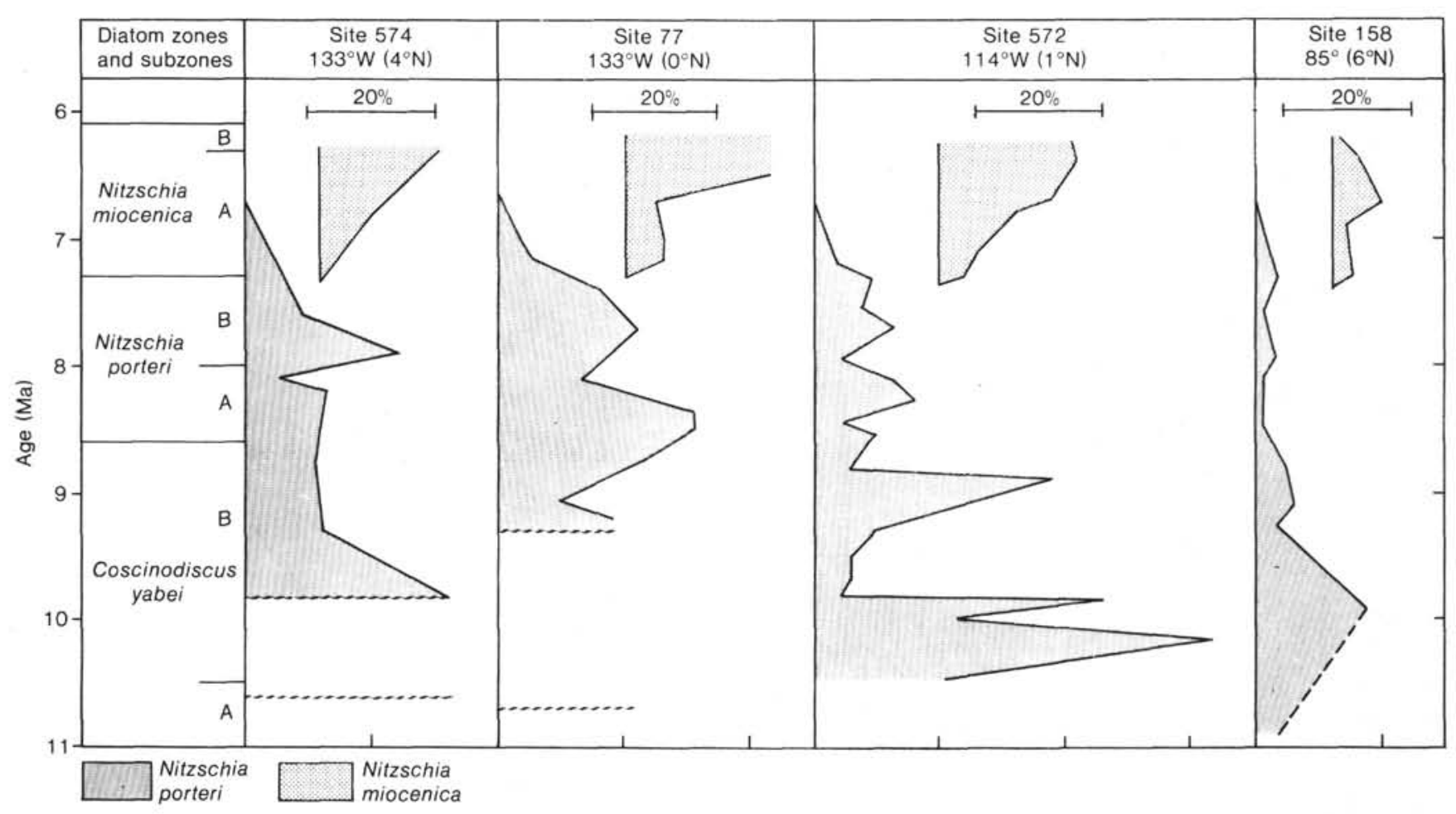

Figure 12. Relative abundance of Nitzschia porteri and N. miocenica s. ampl. (between 10.8 and $6.2 \mathrm{Ma}$ ) at DSDP Sites 574, 77, 572, and 158, plotted against age. Refer to Tables 7 and 10.

Quantitative trends for Thalassiothrix longissima (Fig. 15) reveal numerous correlative abundance spikes (labeled $\mathrm{A}$ to $\mathrm{F}$ ) between the early middle Miocene and the earliest late Miocene (15.3 to $10.9 \mathrm{Ma})$. These peaks are most recognizable in the curves with the closest sampling intervals (Sites 574, 572, and 158), and they are strongly supportive of the diatom datum-level correlations between the sites (Tables 1 and 2). Estimated ages for these spikes are as follows: A, 15.2 Ma; B, 14.7 Ma; C, $13.0 \mathrm{Ma}$; C', $12.7 \mathrm{Ma}$; D, $12.1 \mathrm{Ma}$; $\mathrm{D}^{\prime}, 11.9 \mathrm{Ma}$; E, 11.5 Ma; $\mathrm{E}^{\prime}, 11.3 \mathrm{Ma}$; and F, 10.9 Ma. Absolute abundance values are comparable ( 5 to $20 \%$ ) at Sites 574,77 , and 572 , but slightly greater ( $(10$ to $25 \%$ ) at easternmost Site 158.

\section{REWORKING}

Horizons of reworked diatoms are rare at Sites 572 and 573 and more common at Sites 574 and 575 . The Quaternary through upper Miocene section ( 0 to $26 \mathrm{~m}$ ) of Site 575 accumulated at a very slow rate (Fig. 4), and reworked middle Miocene to Oligocene diatoms are typically present in low numbers. Core 575B-3 (about 7.5 Ma) contains an anomalously thick sequence, and it is dominated by reworked diatoms from the upper middle Miocene, including Coscinodiscus tuberculatus and Denticulopsis punctata f. hustedtii.

At Site 574, upper lower Miocene diatoms are reworked into the lower middle Miocene (Samples 57425, CC and 574-22,CC), and lower middle Miocene diatoms are reworked into the upper middle Miocene (Samples 574-16,CC and 574-14-2, 42-43 cm) (Table 5). Lower and middle Miocene diatoms are also present in upper Miocene (Samples 574A-7, CC and 574A-8,CC) and Pliocene (Samples 574-2,CC; 574A-3,CC; and 574-4,CC) horizons.

\section{SUMMARY}

Excellent upper Eocene to Holocene reference sections were recovered on Leg 85 at four sites ( 572 to 575 ) in the central equatorial Pacific. Diatoms are generally common and well preserved at all sites, except in the upper Eocene and upper Oligocene. The upper Cenozoic diatom zonation of Barron (in press), which consists of the upper Miocene to Holocene zonation of Burckle $(1972,1977)$ and the lower Miocene zonation of Barron (1983), is readily applicable. In addition, 89 secondary datum levels have been identified in the Miocene and Pliocene and correlated between the sites. The Oligocene zonation used is a modification of Fenner's (in press), wherein the upper Oligocene zones are simplified to allow for the relatively poor diatom preservation in that interval. Paleomagnetic stratigraphy was obtained for the entire Denticulopsis nicobarica Zone at Site 575, from the middle of paleomagnetic Chron 17 to the middle of Chron 16, and 13 upper lower Miocene diatom datum levels are calibrated directly with paleomagnetic stratigraphy for the first time.

Site 572 in the east $\left(114^{\circ} \mathrm{W}\right)$ contains a thick sequence of lower middle Miocene to Quaternary diatom-rich sediment. Sites 573 to $575\left(133^{\circ}\right.$ to $\left.135^{\circ} \mathrm{W}\right)$ have more carbonate-rich sediments accumulated at rates that were, at most, $60 \%$ those of Site 572 . Hiatuses are more com- 


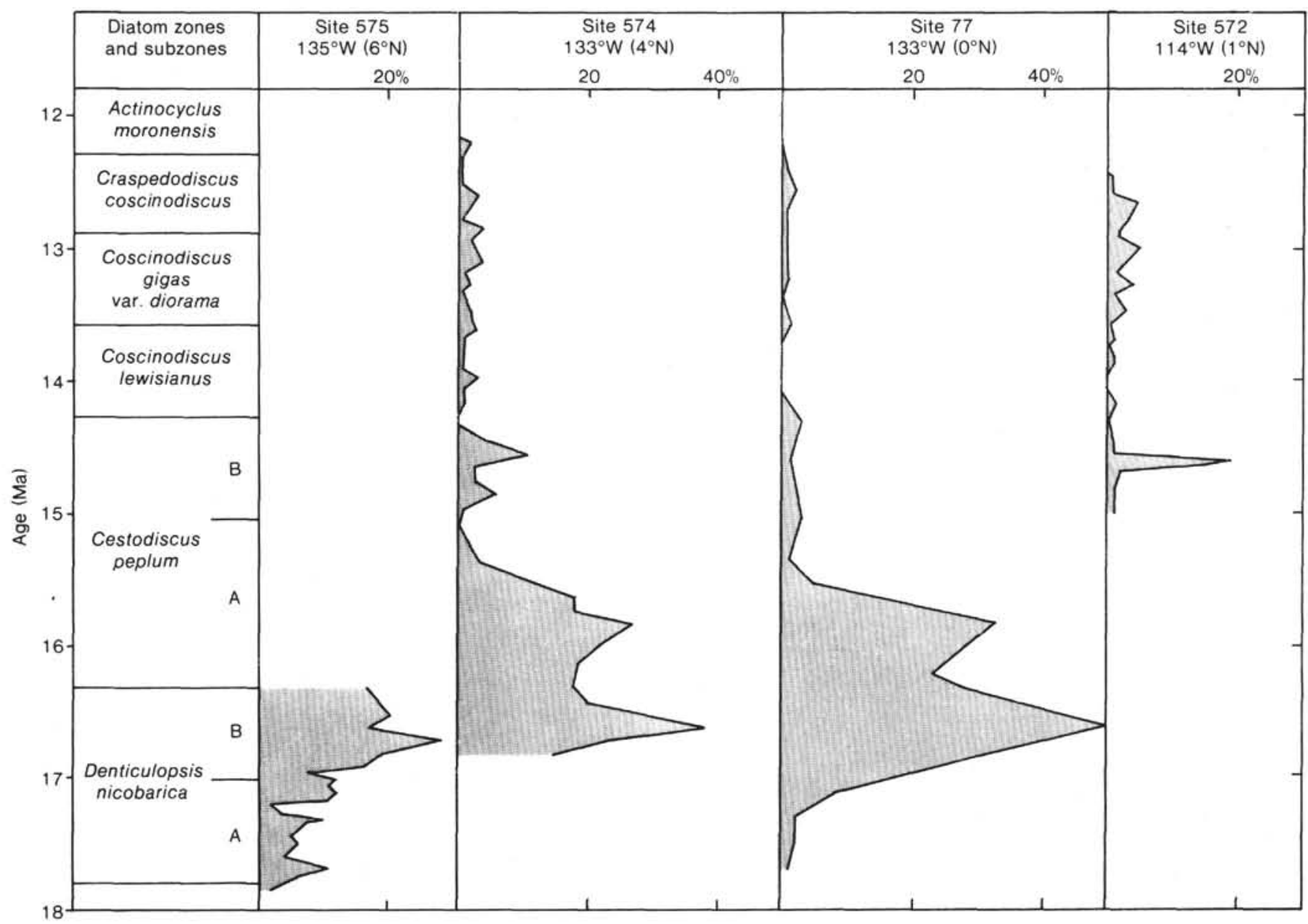

Figure 13. Relative abundance of Synedra jouseana s. ampl. (after $17.8 \mathrm{Ma}$ ) at DSDP Sites 575,574 , 77, and 572, plotted against age. Refer to Tables $4,5,6$, and 8 .

mon at the western sites, specifically in the intervals between about 18 and $17 \mathrm{Ma}(\mathrm{NH} 1), 10.5$ and $9.8 \mathrm{Ma}$ (NH5), and 5.1 and $4.5 \mathrm{Ma}(\mathrm{NH} 7)$.

Quantitative diatom studies of the upper lower Miocene to uppermost Miocene (18.0 to $6.2 \mathrm{Ma}$ ) of Sites 572,574 , and 575 are supplemented by quantitative diatom studies at Site 77 (about $10 \mathrm{~km}$ from Site 573) and Site $158\left(85^{\circ} \mathrm{W}\right)$ to form transects across the eastern and central equatorial Pacific. Where the sampling interval represents 100,000 yrs. or less (lower Miocene of Sites 574 and 575 and middle Miocene of Sites 158, 572, and 574), quantitative trends in species such as Cestodiscus pulchellus, Coscinodiscus radiatus, Denticulopsis hustedtii, D. nicobarica, and Thalassiothrix longissima are readily correlatable, and greatly enhance the biostratigraphic resolution. Sampling intervals for the late Miocene represent an average of 200,000 to 300,000 yrs., and correlation of the individual peaks and troughs of the species abundance curves is more difficult. Comparison of species abundance reveals relatively minor differences between the eastern and western sites, especially in the lower and middle Miocene. Thalassionema nitzschioides, Denticulopsis hustedtii, and D. nicobarica show general eastern preferences, whereas Cestodiscus pul- chellus, Actinocyclus ellipticus, Coscinodiscus tuberculatus, and Nitzschia spp. seem to prefer the western area.

\section{DESCRIPTION OF NEW DIATOM TAXA}

The taxonomy below follows that of Barron (1980a, b; 1981a, b; 1983; in press) for the uppermost Oligocene through Holocene, and that of Jousé (1977) and Fenner (in press) for the Oligocene.

\section{Genus ACTINOCYCLUS Ehrenberg}

Actinocyclus ellipticus Grunow in Van Heurck, 1883 Actinocyclus ellipticus var. spiralis $\mathbf{n}$. var.

(Plate 7, Figs. 9-10; Plate 9, Fig. 5)

Description. This variety is distinguished from other forms of $A$. ellipticus Grunow by its areolation pattern, which closely resembles that of Coscinodiscus lewisianus Greville. Kolbe (1954) characterizes this $C$. lewisianus-type areolation as "apical straight or slightly rounded rows parallel to the apical axis; transapical rows curved and diverging from the transapical axis; central space forming irregular circular figures." Well-developed hyaline fields are present in the valve's center. At low power this taxon closely resembles $C$. lewisianus, but it is easily distinguished by the presence of a marginal pseudonodule. The valves of this variety are not as robust as those of $C$. lewisianus; and smaller specimens, comparable in size to $C$. lewisianus, have apices more tapered than those of $C$. lewisianus. Observed valve sizes range from $40 \times$ $11 \mu \mathrm{m}$ (length $\times$ width) to $70 \times 55 \mu \mathrm{m}$. 


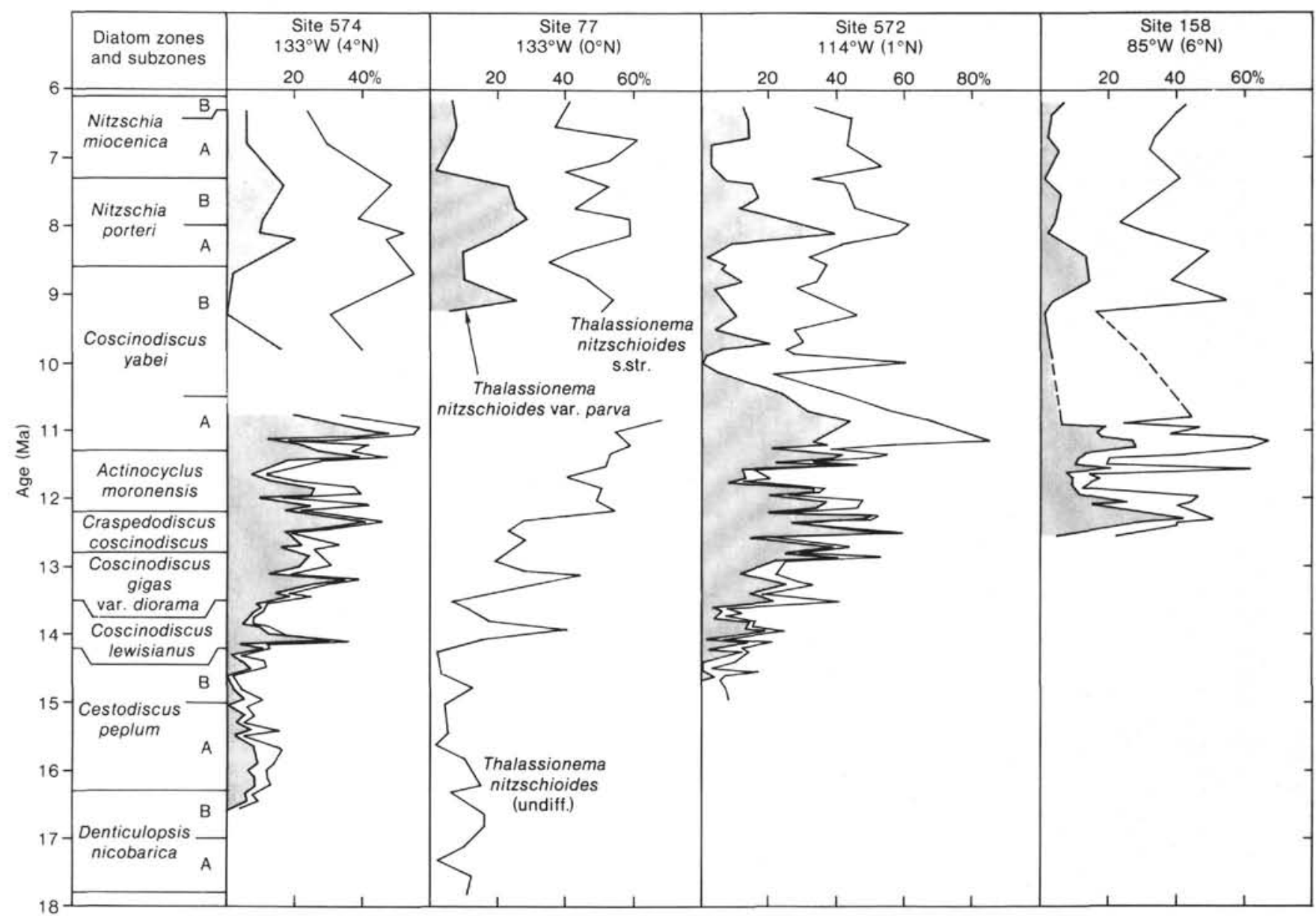

Figure 14. Relative abundance of Thalassionema nitzschioides and $T$. nitzschiodes var. parva (between 17.8 and 6.2 Ma) at DSDP Sites 574, 77, 572, and 158, plotted against age. Refer to Tables 5 to 10 .

Remarks. This variety is separated because it is restricted to the middle Miocene (about 14.2 to 12.3 Ma) (Table 3). Burckle (1978) reported $C$. lewisianus to range above Denticulopsis nicobarica (Grunow) Simonsen in the equatorial Pacific, which conflicts with the results of Barron (1981a, b) and this report. It is possible that Burckle (1978) included $A$. ellipticus var. spiralis in this concept of $C$. lewisianus.

Holotype. USNM 370301. Plate 9, Figure 5. DSDP Sample 575$5-5,43-44 \mathrm{~cm}$. Length $57 \mu \mathrm{m}$.

\section{Genus COSCINODISCUS Ehrenberg}

Coscinodiscus lewisianus Greville 1866

Coscinodiscus lewisianus var. rhomboides, n. var.

(Plate 7, Figs. 2, 3)

Coscinodiscus lewisianus var. similis Rattray, Kolbe, 1954, pl. 2, fig. 22.

C. lewisianus var. similis Rattray, Kanaya, 1971, pl. 40.5, figs. 7, 8 .

C. lewisianus var. similis Rattray, Jousé, 1977, pl. 57, figs. 8, 20-23.

C. lewisianus var. similis Rattray, Barron, 1983, p. 512, pl. 1, fig. 8 .

Description. This variety has distinctly rhombic valves ranging in size from $60 \times 30 \mu \mathrm{m}$ to $120 \times 50 \mu \mathrm{m}$ (length $\times$ width). It has been confused in the literature with $C$. lewisianus var. similis Rattray, which is also rhombic in shape, although much less so (compare Plate 7 , Figs. 2, 3, 6). In addition to being more elliptical in outline, $C$. lewisianus var. similis possesses a distinct, finely areolated margin, which is much broader than the finely areolated margin of $C$. lewisianus var. rhomboides. C. lewisianus var. rhomboides is mainly an upper Oligocene diatom which ranges into the lowermost Miocene, whereas $C$. lewisianus var. similis is restricted to the upper lower Miocene (about 17.4 to $15.7 \mathrm{Ma})$.
Remarks. Barron (1983) recognized the two rhombic forms of $C$. lewisianus, but mistakenly called the older form $C$. lewisianus var. similis Rattray and the younger form $C$. lewisianus ("late early Miocene form resembling $C$. lewisianus var. similis").

Holotype. USNM 370299. DSDP Sample 71-39-2, 87-89 cm. Length $114 \mu \mathrm{m}$.

\section{Coscinodiscus loeblichii, $\mathbf{n} . \mathbf{s p}$. \\ (Plate 4, Figs. 1-3)}

Stictodiscus truanii Witt, Jousé, 1977, pl. 48, fig. 13.

Description. Circular valve 14 to $40 \mu \mathrm{m}$ in diameter with a large, asymmetric indentation at its center. The indentation is not as abrupt as that which is typical of Craspedodiscus, and typically makes up about $4 / 5$ of the valve's face. On opposing sides of the valve, the raised marginal rim varies in thickness by a factor of 2 . The areolar pattern is sublinear, and the polygonal areolae range from 9 per $10 \mu \mathrm{m}$ on the valve's margin to 13 in $10 \mu \mathrm{m}$ near the valve's center. Within the indentation itself, a small area near the valve's center is raised slightly above the surrounding area of the indentation. The valve's margin is simple and without spines.

Remarks. Coscinodiscus loeblichii has a brief range (representing about 10.5 to $9.4 \mathrm{Ma}$ ) in the lower upper Miocene of the equatorial Pacific.

Holotype: USNM 370304. Plate 4, Figure 1. DSDP Sample 572D10,CC. Diameter $28 \mu \mathrm{m}$.

Isotypes. USNM 370305 and 370306 . Plate 4, Figures 2, 3. Diameter $23 \mu \mathrm{m}$ and $30 \mu \mathrm{m}$.

Derivation of name. Named in honor of Dr. Alfred R. Loeblich of the University of California at Los Angeles. 


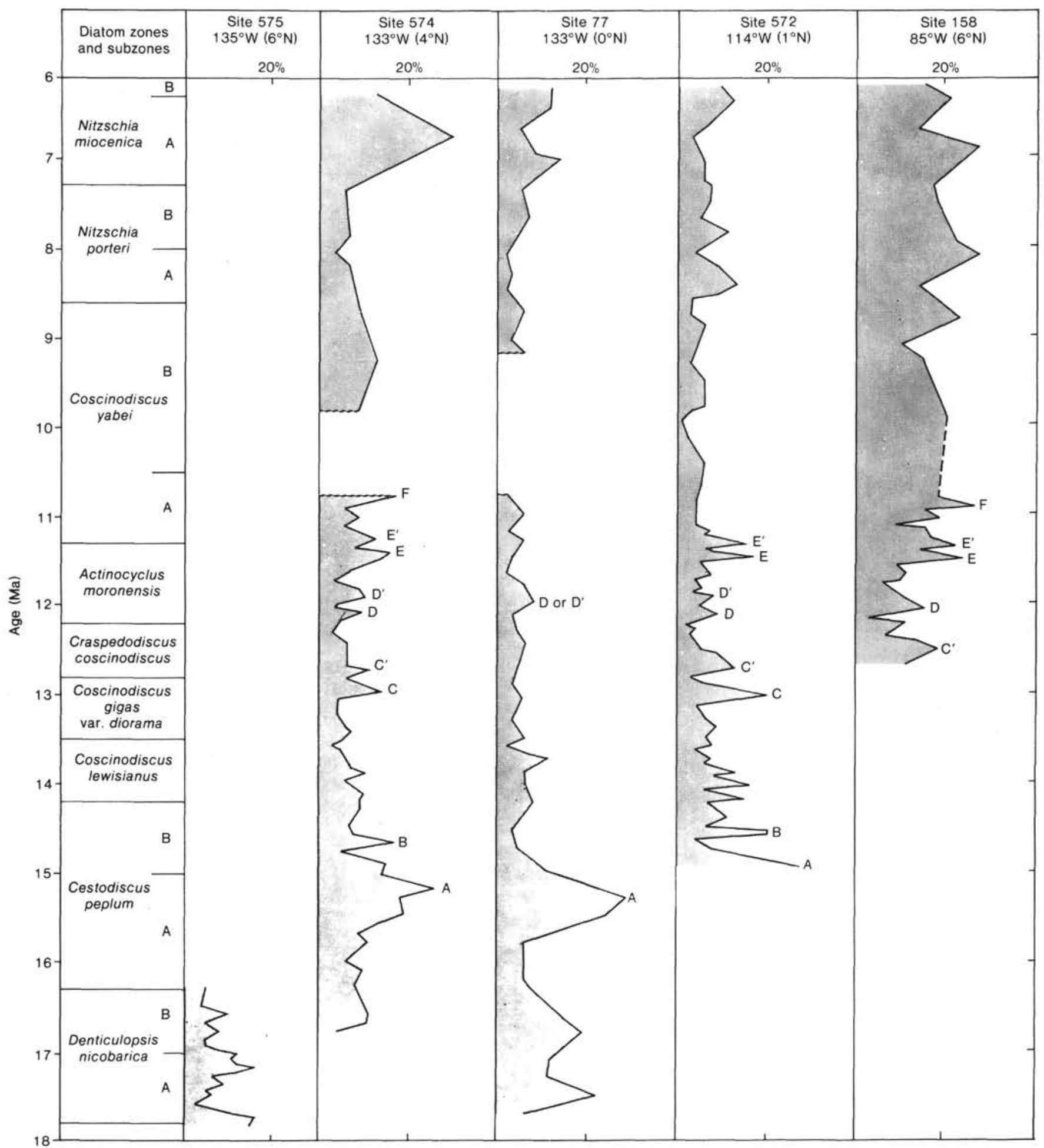

Figure 15. Relative abundance of Thalassiothrix longissima at DSDP Sites 575, 574, 77, 572, and 158 (between 17.8 and 6.2 Ma), plotted against age. Refer to Tables 4 to 10. Correlative abundance peaks are labeled A to F (see text).

Coscinodiscus yabei Kanaya, 1957

Coscinodiscus yabei var. ellipticus, n. var.

(Plate 4, Fig. 9; Plate 9, Fig. 1)

Cymatotheca temperei (Brun) Hendey, Jousé, 1977, pl. 50, fig. 5.

Description. This variety is distinguished by its distinctive elliptical shape. Observed valves range in size from $42 \times 23 \mu \mathrm{m}$ to $96 \times 57 \mu \mathrm{m}$ (length $\times$ width). The plication is always along the transapical (short- er) axis of the valve, in contrast to $C$. temperei Brun, which is always plicated along the apical (longer) axis. Smaller specimens of $C$. yabei var. ellipticus have their axis of plication at a slight angle to the transapical axis, producing an asymmetrical appearance of the plications. Larger specimens have flattened margins covering $1 / 5$ of the transapical axis, with the plication restricted to the center of the valve.

Remarks. C. yabei var. ellipticus has a short range (representing 9.8 to $9.4 \mathrm{Ma}$ ) in the lower upper Miocene (Table 3). 
Holotype. USNM 370307. Plate 4, Figure 9. DSDP Sample 572D$10-4,50-52 \mathrm{~cm}$. Length $63 \mu \mathrm{m}$.

Isotype. USNM 370308. Plate 9, Figure 1. Length $46 \mu \mathrm{m}$.

\section{Genus THALASSIOSIRA Cleve \\ Thalassiosira tappanae, n. sp. (Plate 6, Figs. 1-5, 7)}

?Stephanopyxis sp., Bukry, 1978b, pl. 19, fig. 10.

Coscinodiscus sp. of Burckle (1978), Barron, 1981a, p. 139.

Description. Small (10 to $14 \mu \mathrm{m}$ diameter), circular valves which are robust and slightly convex. Subpolygonal areolae are arranged in a linear to slightly eccentric pattern, and range in size from 9 per $20 \mu \mathrm{m}$ near the valve center to 11 per $10 \mu \mathrm{m}$ near the valve margin. Characteristic "gear-like" margin contains robust double spines ( $1 \mu \mathrm{m}$ long) dispersed every 1.5 to $2 \mu \mathrm{m}$ along a hyaline $1-\mu \mathrm{m}$-wide margin. There are typically 15 to 18 such spines per valve. Seven marginal strutted processes and one possible labiate process were observed on the interior face of the valve (Plate 6, Fig. 3).

Remarks. T. tappanae has a short range (representing 14.4 to $13.8 \mathrm{Ma}$ ) in the middle middle Miocene of the tropical Pacific. It was referred to as Coscinodiscus sp. by Burckle (1978) but was not described or figured.

Holotype. USNM 370309. Plate 6, Figure 7. DSDP Sample 572D28-2, 50-52 cm. Diameter $12.5 \mu \mathrm{m}$.

Isotype. USNM 370310. Plate 6, Figure 5. Diameter $13 \mu \mathrm{m}$.

Derivation of name. Named in honor of Dr. Helen Tappan of the University of California at Los Angeles.

\section{OTHER DIATOM TAXA OBSERVED}

Actinocyclus ehrenbergii Ralfs

A. ellipticus Grunow

A. ellipticus $\mathrm{f}$. lanceolata Kolbe

A. ellipticus var. javanica Reinhold

A. hajosiae Barron

A. ingens Rattray

A. moronensis Deby

A. radionovae Barron

Actinoptychus undulatus (Bailey) Ralfs

Annellus californicus Tempére

Asterolampra acutiloba Frenguelli

Asteromphalus elegans Greville

Bogorovia veniamini Jousé

Cestodiscus peplum Brun

C. pulchellus Greville

C. pulchellus Greville sensu Jousé, 1973

C. mukhinae Jousé

C. robustus Jousé

Coscinodiscus africanus Janisch

C. blysmos Barron

C. excavatus Ralfs

C. gigas var. diorma (Schmidt) Grunow

C. lewisianus Greville

C. lewisianus var. robustus Barron

C. lewisianus var. similis Rattray

C. marginatus Ehrenberg

C. nodulifer A. Schmidt

C. nodulifer var. cyclopus Jousé

C. oligocenicus Jousé

C. plicatus Grunow

C. praenodulifer Barron

C. radiatus Ehrenberg

C. rhombicus Castracane

C. salisburyanus Lohman

C. tabularis Grunow

C. temperei var. delicata Barron

C. tuberculatus Greville

C. vetustissimus var. javanica Reinhold

C. yabei Kanaya

Craspedodiscus coscinodiscus Ehrenberg

C. elegans Ehrenberg

C. rydei Barron

Denticulopsis hustedtii (Simonsen and Kanaya) Simonsen

$K$. kanayae (Aliba) Barron
D. lauta (Bailey) Simonsen

D. nicobarica (Grunow) Simonsen

D. praedimorpha (Akiba) Akiba

D. punctata f. hustedtii (Schrader) Simonsen

Hemidiscus cuneiformis Wallich

Lisitzinia ornata Jousé

Melosira architecturalis Brun

M. sulcata (Ehrenberg) Kutzing

Nitzschia cyclindrica Burckle

N. fossilis (Frenguelli) Kanaya and Koizumi

$N$. jouseae Burckle

N. maleinterpretaria Schrader

$N$. marina Grunow

N. miocenica Burckle

$N$. miocenica var. elongata Burckle

$N$. porteri Frenguelli sensu Burckle (1972)

$N$. praereinholdii Schrader

$N$. reinholdii Kanaya and Koizumi

Pseudoeunotia doliolus (Wallich) Grunow

Raphidodiscus marylandicus Christian

Rhizosolenia matuyamai Burckle

$R$. praebergonii Mukhina

$R$. praebergonii var. robusta Burckle and Trainer

Rocella gelida (Mann) Bukry

$R$. gelida var. schraderi (Bukry) Barron

$R$. vigilans Fenner

Rossiella paleacea (Grunow) Desikachary and Maheshwari

$R$. paleacea var. elongata (Barron)

$R$. praepaleacea (Schrader) Gersonde

Rouxia spp.

Synedra miocenica Schrader

S. jouseana Sheshukova-Poretzkaya

S. jouseana f. linearis Sheshukova-Poretzkaya

Thalassionema nitzschioides Grunow

T. nitzschioides var. parva Heiden and Kolbe

T. robusta Schrader

Thalassiosira bukryi Barron

T. burckliana Schrader

T. convexa Mukhina

T. convexa var. aspinosa Schrader

T. eccentrica (Ehrenberg) Cleve

T. fraga Schrader

T. leptopus (Grunow) Hasle and Fryxell

T. miocenica Schrader

T. oestrupii (Ostenfeld) Proshkina-Lavrenko

T. praeconvexa Burckle

T. primalabiata Gombos

T. spinosa Schrader

T. spumellaroides Schrader

Thalassiothrix longissima Cleve and Grunow

Triceratium cinnamomeum Greville

T. pileus Ehrenberg

\section{ACKNOWLEDGMENTS}

I thank the Leg 85 Co-Chiefs, Larry Mayer and Fritz Theyer, and the entire staff for making Leg 85 rewarding and successful. This manuscript benefited from the reviews of William $\mathrm{H}$. Abbott and Lloyd $\mathrm{H}$. Burckle. Jack G. Baldauf and David Bukry provided helpful comments. Robert Oscarson of the U. S. Geological Survey assisted with scanning electron microscope studies. Samples were made available for study by the NSF through the Deep Sea Drilling Project.

\section{REFERENCES}

Barron, J. A., 1980a. Miocene to Quaternary diatom biostratigraphy of DSDP Leg 57, off northeast Japan. In Scientific Party, Init. Repts. DSDP, 56, 57, Pt. 2: Washington (U.S. Govt. Printing Office), 641-685.

, 1980b. Upper Pliocene and Quaternary diatom biostratigraphy of Deep Sea Drilling Project Leg 54, tropical eastern Pacific. In Rosendahl, B. R., Hekinian, R., et al., Init. Repts. DSDP, 54: Washington (U.S. Govt. Printing Office), 455-485.

$\therefore$, 1981a. Late Cenozoic diatom biostratigraphy and paleoceanography of the middle-latitude eastern North Pacific. In Yeats, R. 
S., Haq, B. U., et al., Init. Repts. DSDP, 63: Washington (U.S. Govt. Printing Office), 507-538.

1981b. Middle Miocene diatom biostratigraphy of DSDP Site 77B in the eastern equatorial Pacific. Geosci. J., 2(2):137-144. 1983. Latest Oligocene through early middle Miocene diatom biostratigraphy of the eastern tropical Pacific. Mar. Micropaleontol., 7:487-515.

in press. Miocene to Quaternary planktic diatom biostratigraphy. In Bolli, H. M., and Saunders, J. B. (Eds.), Biostratigraphy by Marine Plankton: Cambridge (Cambridge Univ. Press).

Barron, J. A., and Keller, G., 1983. Paleotemperature oscillations in the middle and late Miocene of the northeastern Pacific. Micropaleontology, 29(2): 150-181.

Barron, J. A., Keller, G., and Dunn, D. A., in press. A multiple microfossil biochronology for the Miocene. In Kennett, J. P. (Ed.), The Miocene Ocean: Paleoceanography and Biogeography. Mem. Geol. Soc. Am. 163.

Berggren, W. A., 1981. Correlation of Atlantic, Mediterranean, and Indo-Pacific Neogen stratigraphies: geochronology and chronostratigraphy. Proc. IGCP Project 114: Internat. Workshop Pacific Neogene Biostratig. (Nov. 25-29, 1981, Osaka and Kobe, Japan), pp. 29-60.

Berggren, W. A., Kent, D. V., and Flynn, J. J., in press. Paleogene geochronology and chronostratigraphy. In Snelling, N. J. (Ed.), Geochronology and the Geologic Time Scale.

Bukry, D., 1973. Phytoplankton stratigraphy, central Pacific Ocean, Deep Sea Drilling Project Leg 17. In Winterer, E. L., Ewing, J. I., et al., Init. Repts. DSDP, 17: Washington (U.S. Govt. Printing Office), 871-887.

1978a. Cenozoic coccolith and silicoflagellate stratigraphy, offshore northwest Africa, Deep Sea Drilling Project Leg 41. In Lancelot, Y., Seibold, E., et al., Init. Repts. DSDP, 41: Washington (U.S. Govt. Printing Office), 689-707.

1978b. Cenozoic coccolith, silicoflagellate, and diatom stratigraphy, Deep Sea Drilling Project Leg 44. In Benson, W. E., Sheridan, R. E., et al., Init. Repts. DSDP, 44: Washington (U.S. Govt. Printing Office), 807-863.

Bukry, D., and Foster, J. H., 1973. Silicoflagellate and diatom stratigraphy, Leg 16, Deep Sea Drilling Project. In van Andel, T. H., Heath, G. R., et al., Init. Repts. DSDP, 16: Washington (U.S. Govt. Printing Office), 815-871.

Burckle, L. H., 1972. Late Cenozoic planktonic diatom zones from the eastern equatorial Pacific. Nova Hedwigia, 39:217-246.

1977. Pliocene and Pleistocene diatom datum levels from the equatorial Pacific. Quat. Res., 7:330-340.

1978. Early Miocene to Pliocene diatom datum levels for the equatorial Pacific. Proc. Second Working Group Mtg., Biostratig. Datum-Planes Pacific Neogene, IGCP Project 114 (Bandung, Indonesia, May 30-June 1, 1977). Spec. Publ. Geol. Res. Dev. Ctr., 1:25-44.

Burckle, L. H., Hammond, S. R., and Seyb, S. M., 1978. A stratigraphically important new diatom from the Pleistocene of the North Pacific. Pacific Sci., 32(2):209-214.

Burckle, L. H., Keigwin, L. D., and Opdyke, N. D., 1982. Middle and late Miocene stable isotope stratigraphy: correlation to the paleomagnetic reversal record. Micropaleontology, 28(4):329-334.

Burckle, L. H., and Opdyke, N. D., 1977. Late Neogene diatom correlations in the circum-Pacific. Proc. First Internat. Congr. Pacific Neogene Stratig. (Tokyo, 1976): Tokyo (Kaiyo Shuppan Co. Ltd.), pp. 255-284.

Burckle, L. H., and Trainer, J., 1979. Middle and late Pliocene diatom datum levels from the central Pacific. Micropaleontology, 25(3): 281-293.

Ciesielski, P. F., 1983. The Neogene and Quaternary diatom biostratigraphy of subantarctic sediments, Deep Sea Drilling Project Leg 71. In Ludwig, W. J., and Krasheninnikov, V. A., et al., Init. Repts. DSDP, 71: Washington (U.S. Govt. Printing Office), 635-665.

Dunn, D. A., 1982. Miocene sediments of the Pacific Ocean: carbonate stratigraphy and dissolution history [Ph.D. dissert.]. Univ. Rhode Island, Narragansett.

Fenner, J., 1977. Cenozoic diatom biostratigraphy of the equatorial and Southern Atlantic Ocean. In Supko, P. R., Perch-Nielsen, K., et al., Init. Repts. DSDP, Suppl. to Vols. 38, 39, 40, and 41: Washington (U.S. Govt. Printing Office), 491-624.
1984. Eocene-Oligocene planktic diatom stratigraphy in the low latitudes and high southern latitudes. Micropaleontology, 30(4):319-342

, in press. Paleogene and Late Cretaceous planktic diatom stratigraphy. In Bolli, H. M., and Saunders, J. B. (Eds.), Biostratigraphy by Marine Plankton: Cambridge (Cambridge Univ. Press).

Gombos, A. M., Jr., 1975. Fossil diatoms from Leg 7, Deep Sea Drilling Project. Micropaleontology, 21(3):306-333.

1976. Paleogene and Neogene diatoms from the Falkland Plateau and Malvinas Outer Basin: Leg 36, Deep Sea Drilling Project. In Barker, P., Dalziel, I. W. D., et al., Init. Repts. DSDP, 36: Washington (U.S. Govt. Printing Office), 575-687.

Gombos, A. M., Jr., and Ciesielski, P. F., 1983. Late Eocene to early Miocene diatoms from the southwest Atlantic. In Ludwig, W. J., Krasheninnikov, V. A., et al., Init. Repts. DSDP, 71: Washington (U.S. Govt. Printing Office), 583-634.

Haq, B. U., Worsley, J. R., Burckle, L. H., Douglas, R. G., Keigwin, L. D., et al., 1980. Late Miocene marine carbon-isotope shift and synchroneity of some phytoplanktic biostratigraphic events. Geology, 8:427-431.

Harper, H. E., Jr., Rider, J., and Abbott, W. H., 1982. Diatom biostratigraphy of Sites 495, 496, and 497, Deep Sea Drilling Project Leg 67. In Aubouin, J., von Huene, R., et al., Init. Repts. DSDP, 67: Washington (U.S. Govt. Printing Office), 447-454.

Harwood, D. M., 1982. Oligocene-Miocene diatom biostratigraphy from the equatorial to the Antarctic Pacific [Master's thesis]. Florida State University, Tallahassee.

Hays, J. D., et al., 1972. Init. Repts. DSDP, 9: Washington (U.S. Govt. Printing Office).

Jousé, A. P., 1968. New species of diatoms in bottom sediments of the Pacific and the Sea of Okhotsk. Nov. System. Plant. non Vascular 1968, Akad. Nauk. SSSR, 3:12-21. (In Russian.)

, 1973. Diatoms in the Oligocene-Miocene biostratigraphic zones of the tropical areas of the Pacific Ocean. Nova Hedwigia, 45:333-364.

1977. Atlas of Microorganisms in Bottom Sediments of the Oceans: Diatoms, Radiolaria, Silicoflagellates, and Coccoliths: Moscow (Nauka).

Kanaya, T., 1971. Some aspects of pre-Quaternary diatoms in the oceans. In Riedel, W. R., and Funnell, W. M. (Eds.), Micropaleontology of the Oceans: Cambridge (Cambridge Univ. Press), pp. 545-565.

Keller, G., and Barron, J. A., 1983. Paleoceanographic implications of Miocene deep sea hiatuses. Geol. Soc. Am. Bull., 94:590-613.

Keller, G., Barron, J. A., and Burckle, L. H., 1982. Paleomagnetic, stable isotope, carbonate, and microfossil stratigraphies in upper Miocene sediments in the North Pacific Ocean. Mar. Micropaleontol., 7:327-357.

Koizumi, I., 1973. The late Cenozoic diatoms of Sites 183-193, Leg 19. In Creager, J. S., Scholl, D. W., et al., Init. Repts. DSDP, 19: Washington (U.S. Govt. Printing Office), 805-855.

Kolbe, R., 1954. Diatoms from the equatorial Pacific cores. Rep. Swed. Deep Sea Exped., 1947-1948, 6:1-49.

Mukhina, V. V., 1963. Biostratigraphic analysis of bottom sediments from Station 3802 in the equatorial zone of the Pacific Ocean. Okeanologiya, 3:861-869. (In Russian.)

, 1965. New species of diatoms from bottom sediments of the equatorial region of the Pacific. Nov. System. Plant. non Vascularium, Bot. Inst. Akad. Nauk. SSSR, pp. 22-25. (In Russian with systematic description of species in Latin.)

1966. The boundary between sediments of Quaternary and Tertiary age in the Pacific (on the basis of diatom analysis). Oceanology, 6:99-110.

1969. Biostratigraphy of sediments and some questions of paleogeography of the tropical region of Pacific and Indian oceans In Jousé, A. P. (Ed.), Micropaleontology and Organogenous Sedimentation in the Oceans: Moscow (Izd. Nauka), 52-84.

Opdyke, N. D., Burckle, L. H., and Todd, A., 1974. The extension of the magnetic time scale in sediments of the central Pacific Ocean. Earth Planet. Sci. Lett., 22:300-306.

Poore, R. Z., Tauxe, L., Percival, S. F., Jr., LaBrecque, J. L., Wright, R., et al., 1983. Late Cretaceous-Cenozoic magnetostratigraphic and biostratigraphic correlations of the South Atlantic Ocean: DSDP Leg 73. Palaeogeogr. Palaeoclim. Palaeoecol., 42:127-149. 
Ryan, W. B. F., Cita, M. B., Rawson, M. D., Burckle, L. H., and Saito, T., 1974. A paleomagnetic assignment of Neogene stage boundaries and the development of isochronous datum planes between the Mediterranean, the Pacific and Indian oceans in order to investigate the response of the world ocean to the Mediterranean "salinity crisis." Riv. Ital. Paleontol., 80:631-688.

Sancetta, C. A., 1982. Diatom biostratigraphy and paleoceanography, Deep Sea Drilling Project Leg 68. In Prell, W. L., Gardner, J. V., et al., Init. Repts. DSDP, 68: Washington (U.S. Govt. Printing Office), 301-310.

, 1983. Biostratigraphic and paleoceanographic events in the eastern equatorial Pacific: results of Deep Sea Drilling Project Leg 69. In Cann, J. R., Langseth, M. G., Honnorez, J., Von Herzen, R. P., White, S. M., et al., Init. Repts. DSDP, 69: Washington (U.S. Govt. Printing Office), 311-342.

Savin, S. M., Douglas, R. G., Keller, G., Killingley, J. S., Shaughnessy, L., et al., 1981. Miocene benthic foraminiferal isotope records: a synthesis. Mar. Micropaleontol., 6:423-450.
Schrader, H. J., 1974. Cenozoic marine planktonic diatom stratigraphy of the tropical Indian Ocean. In Fisher, R. L., Bunce, E. T., et al., Init. Repts. DSDP, 24: Washington (U.S. Govt. Printing Office), 887-967.

Schrader, H. J., and Gersonde, R., 1978. Diatoms and silicoflagellates. Utrecht Micropal. Bull., 17:1129-1176.

van Andel, T. H., Heath, G. R., and Moore, T. C., Jr., 1975. Cenozoic history and paleoceanography of the central equatorial Pacific Ocean. Mem. Geol. Soc. Am. 143.

Weaver, F. M., and Gombos, A. M., Jr., 1981. Southern high-latitude diatom biostratigraphy. Spec. Publ. Soc. Econ. Paleontol. Mineral., 32:445-470.

Woodruff, F., Savin, S. M., and Douglas, R. G., 1981. Miocene stable isotope record: a detailed deep Pacific Ocean study and its paleoclimatic implications. Science, 212:665-668.

Date of Initial Receipt: 10 October 1983

Date of Acceptance: 6 March 1984 

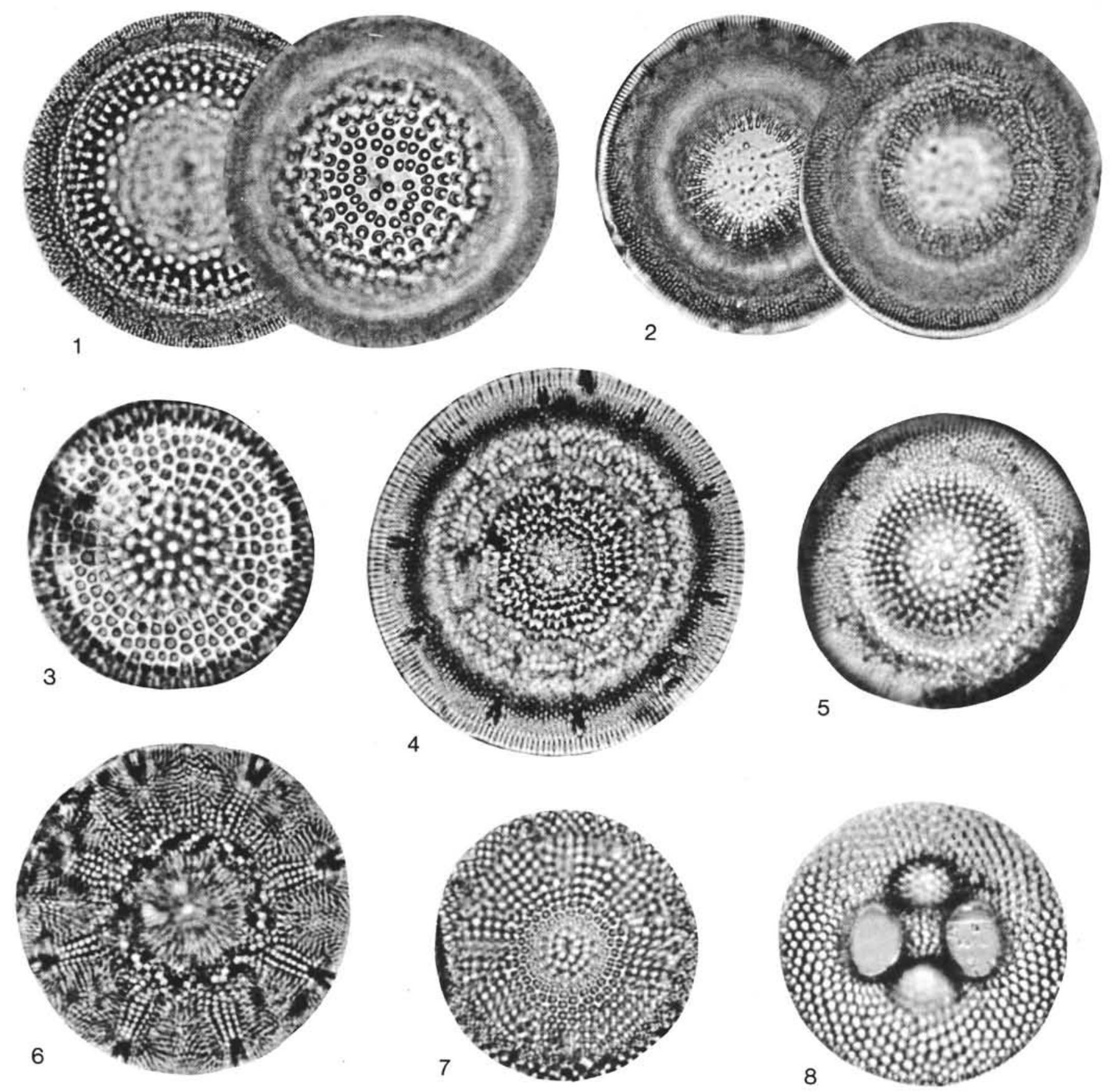

Plate 1. 1. Cestodiscus robustus Jousé, low and high focus, diameter $92 \mu \mathrm{m}$, Sample 574C-28,CC. 2. Actinocyclus radionovae Barron, low and high focus, diameter $75 \mu \mathrm{m}$, Sample $574 \mathrm{C}-6-2,43-45 \mathrm{~cm}$. 3. Cestodiscus mukhinae Jousé, diameter $33 \mu \mathrm{m}$, Sample 574C-22,CC. 4. Cestodiscus pulchellus var. maculatus Kolbe, diameter $40 \mu \mathrm{m}$, Sample 77B-28-2, 28-30 cm. 5. Cestodiscus pulchellus Greville sensu Jousé (1977), diameter $52 \mu \mathrm{m}$, Sample 574C-31,CC. 6. Aulacodiscus sp. (figured by Jousé [1977] as Actinodiscus barbadensis Greville), diameter $54 \mu \mathrm{m}$, Sample 574C-17,CC. 7. Cestodiscus pulchellus Greville, diameter $41 \mu \mathrm{m}$, Sample 77B-25-6, 20-22 cm. 8. Coscinodiscus excavatus Ralfs, diameter $130 \mu \mathrm{m}$, Sample 573B-37,CC. 

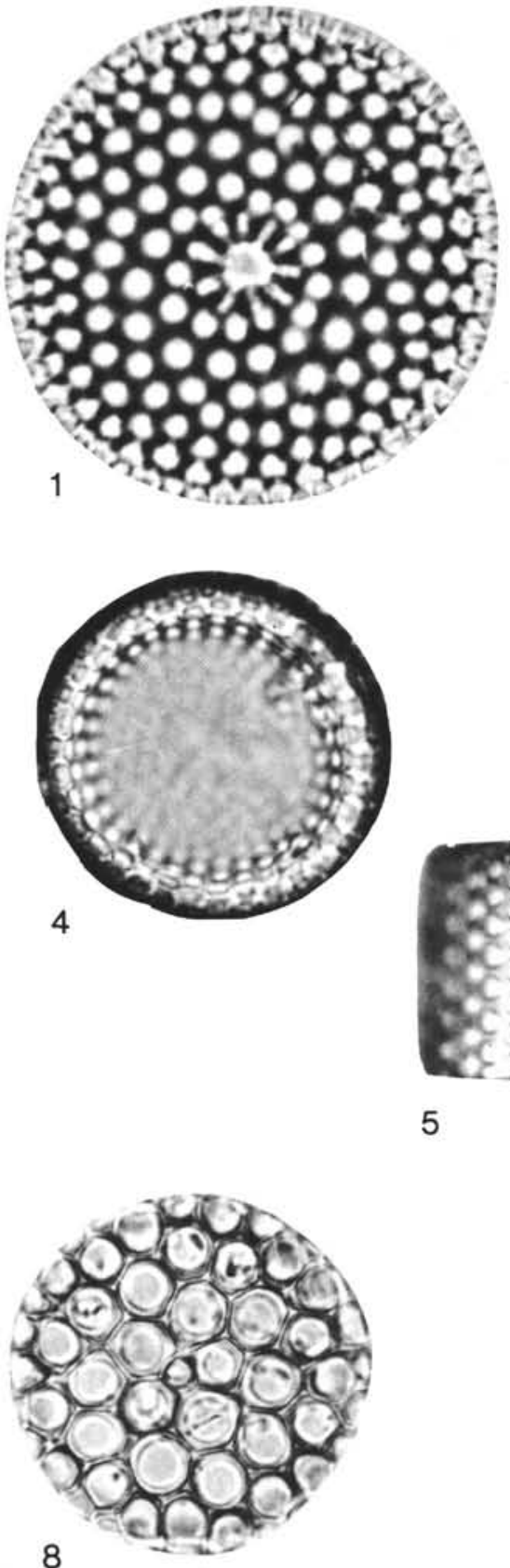

5
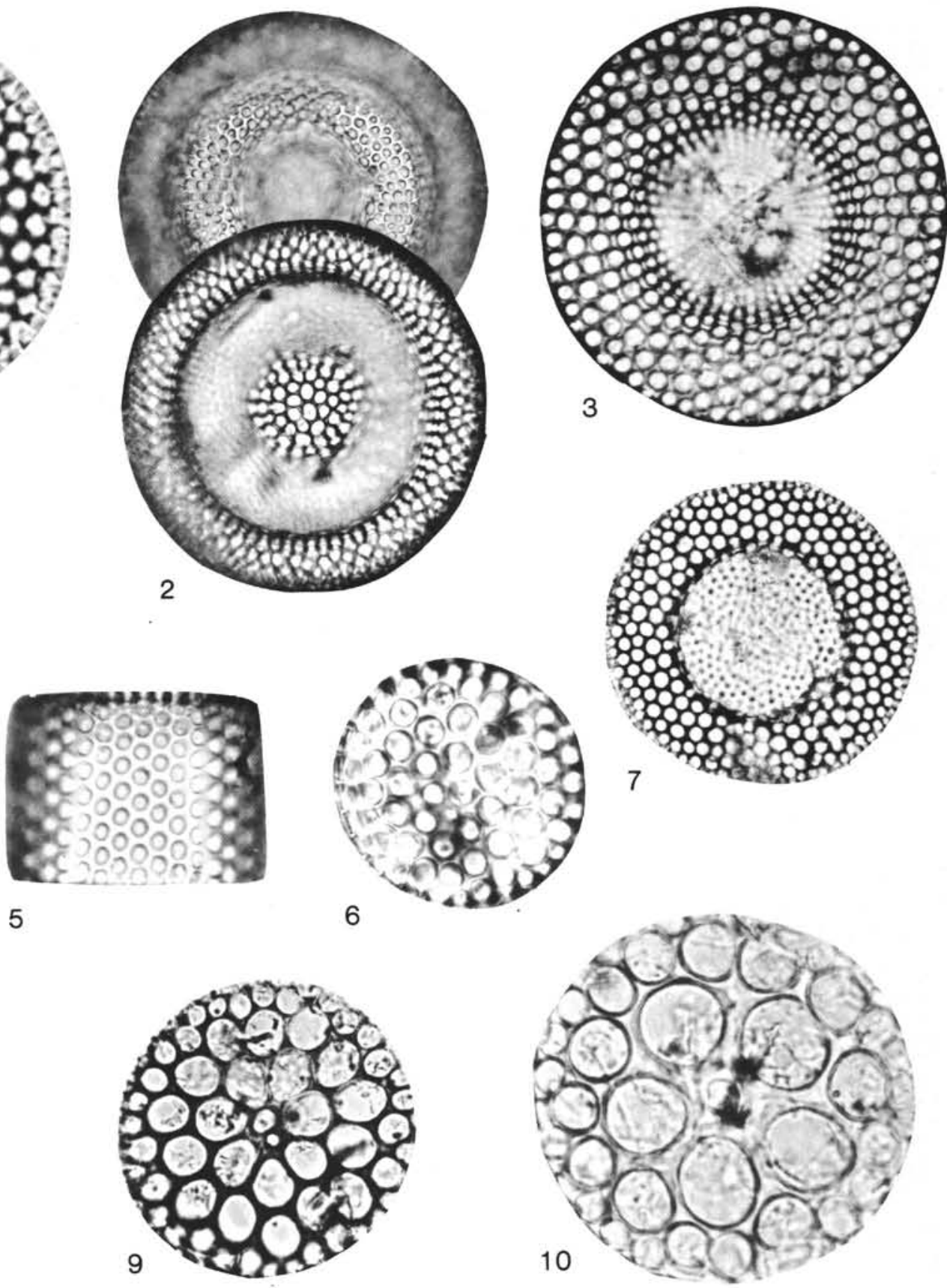

Plate 2. 1. Coscinodiscus blysmos Barron, diameter $40 \mu \mathrm{m}$, Sample $575 \mathrm{~A}-2-3,42-43 \mathrm{~cm}$. 2. Craspedodiscus elegans Ehrenberg, low and high focus, diameter $107 \mu \mathrm{m}$, Sample 575A-17,CC. 3. Craspedodiscus coscinodiscus Ehrenberg s. ampl., coarse indented form of the late Oligocene, diameter $148 \mu \mathrm{m}$, Sample 574C-17-2, 43-45 cm. 4. Craspedodiscus rydei Barron, diameter $34 \mu \mathrm{m}$, Sample 575A-3-2, 42-43 cm. 5. Annellus californicus Tempère, width $39 \mu \mathrm{m}$, Sample 575B-12-6, 105-106 cm. 6. Rocella vigilans (Schmidt) Fenner, plicate form, diameter $30 \mu \mathrm{m}$, Sample 574C-17,CC. 7. Craspedodiscus coscinodiscus Ehrenberg s. str., diameter $72 \mu \mathrm{m}$, Sample 574-16-2, 42-43 cm. 8-9. Rocella gelida (Mann) Bukry, (8) diameter $34 \mu \mathrm{m}$, Sample 574C-17,CC, (9) diameter $66 \mu \mathrm{m}$, Sample 574C-17-2, 43-45 cm. 10. Rocella gelida var. schraderi (Bukry) Barron, diameter $47 \mu \mathrm{m}$, Sample 574C-16,CC. 

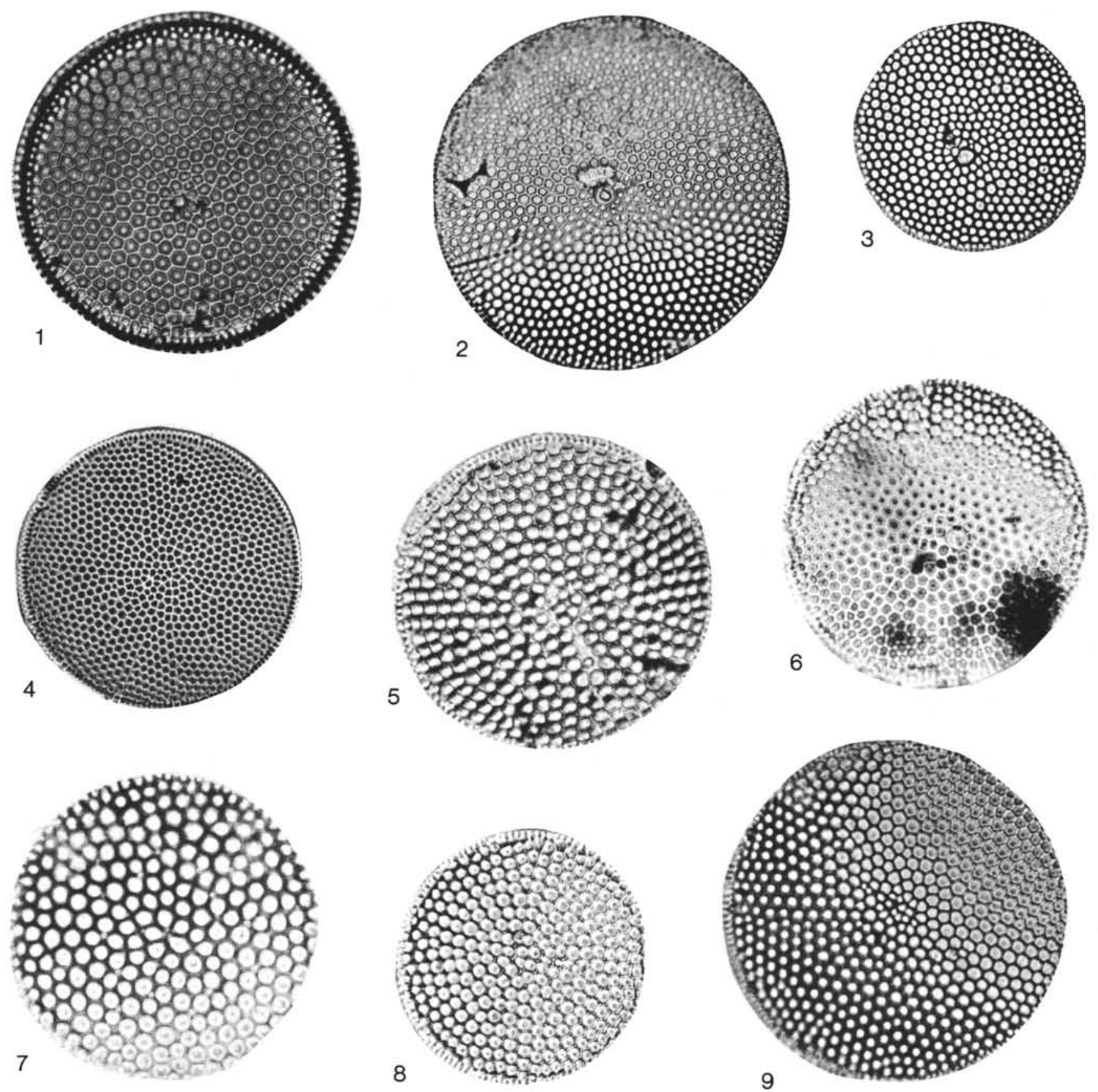

Plate 3. 1. Coscinodiscus nodulifer A. Schmidt, diameter $54 \mu \mathrm{m}$, Sample $572 \mathrm{~A}-6-3,42-43 \mathrm{~cm}$. 2. Coscinodiscus nodulifer var. cyclopus Jousé, Miocene form, clear area above center is bubble in mounting medium; diameter $91 \mu \mathrm{m}$, Sample $574-8-1,43-45 \mathrm{~cm}$. 3. Coscinodiscus nodulifer var. cyclopus Jousé s. str., diameter $60 \mu \mathrm{m}$, Sample 573-8,CC. 4. Coscinodiscus tabularis Grunow, diameter 46 $\mu \mathrm{m}$, Sample 574-10-6, 43$45 \mathrm{~cm}$. 5. Coscinodiscus oligocenicus Jousé, diameter $39 \mu \mathrm{m}$, Sample 574C-31,CC. 6. Coscinodiscus vetustissimus var. javanica Reinhold, diameter $29 \mu \mathrm{m}$, Sample 77B-17-1, 18-20 cm. 7. Coscinodiscus radiatus Ehrenberg, diameter $59 \mu \mathrm{m}$, Sample 574-20,CC. 8. Coscinodiscus tuberculatus Greville, diameter $36 \mu \mathrm{m}$, Sample 574-11-4, 43-45 cm. 9. Coscinodiscus salisburyanus Lohman, diameter 47 $\mu \mathrm{m}$, Sample 574-20-2, $43-44 \mathrm{~cm}$. 

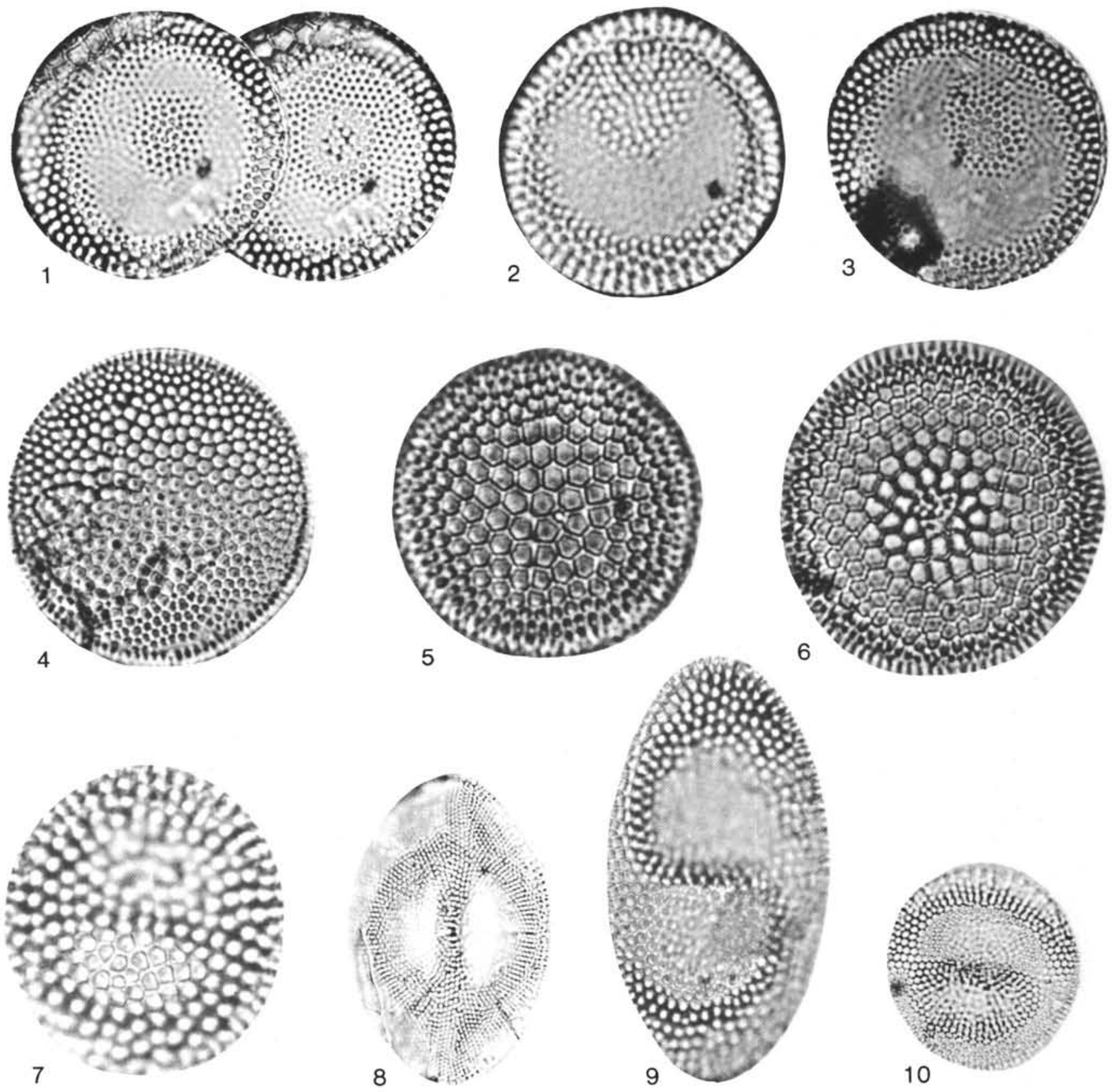

Plate 4. 1-3. Coscinodiscus loeblichii Barron, n. sp., Sample 572D-10,CC, (1) Holotype USNM 370304, high and low focus, diameter $28 \mu \mathrm{m}$, (2) Isotype USNM 370305, diameter $23 \mu \mathrm{m}$, (3) Isotype USNM 370306, diameter $30 \mu \mathrm{m}$. 4. Thalassiosira bukryi Barron, diameter $33 \mu \mathrm{m}$, Sample 575A-6-3, 42-43 cm. 5. Thalassiosira oestrupii (Ostenfeld) Proshkina-Lavrenko, diameter $24 \mu \mathrm{m}$, Sample 572A-1-3, 67-68 cm. 6. Thalassiosira burckliana Schrader, diameter $15 \mu \mathrm{m}$, Sample 77B-15-6, 23-25 cm. 7. Coscinodiscus yabei Kanaya, diameter 24 $\mu \mathrm{m}$, Sample 5748,CC. 8. Coscinodiscus temperi var. delicata Barron, length $57 \mu \mathrm{m}$, Sample 574-10-5, $43-45 \mathrm{~cm}$. 9. Coscinodiscus yabei var. ellipticus Barron, n. var., Holotype USNM 370307, length $63 \mu \mathrm{m}$, Sample 572D-10-4, 50-52 cm. 10. Coscinodiscus plicatus Grunow, diameter $46 \mu \mathrm{m}$, Sample 574-10-5, 43-45 cm. 

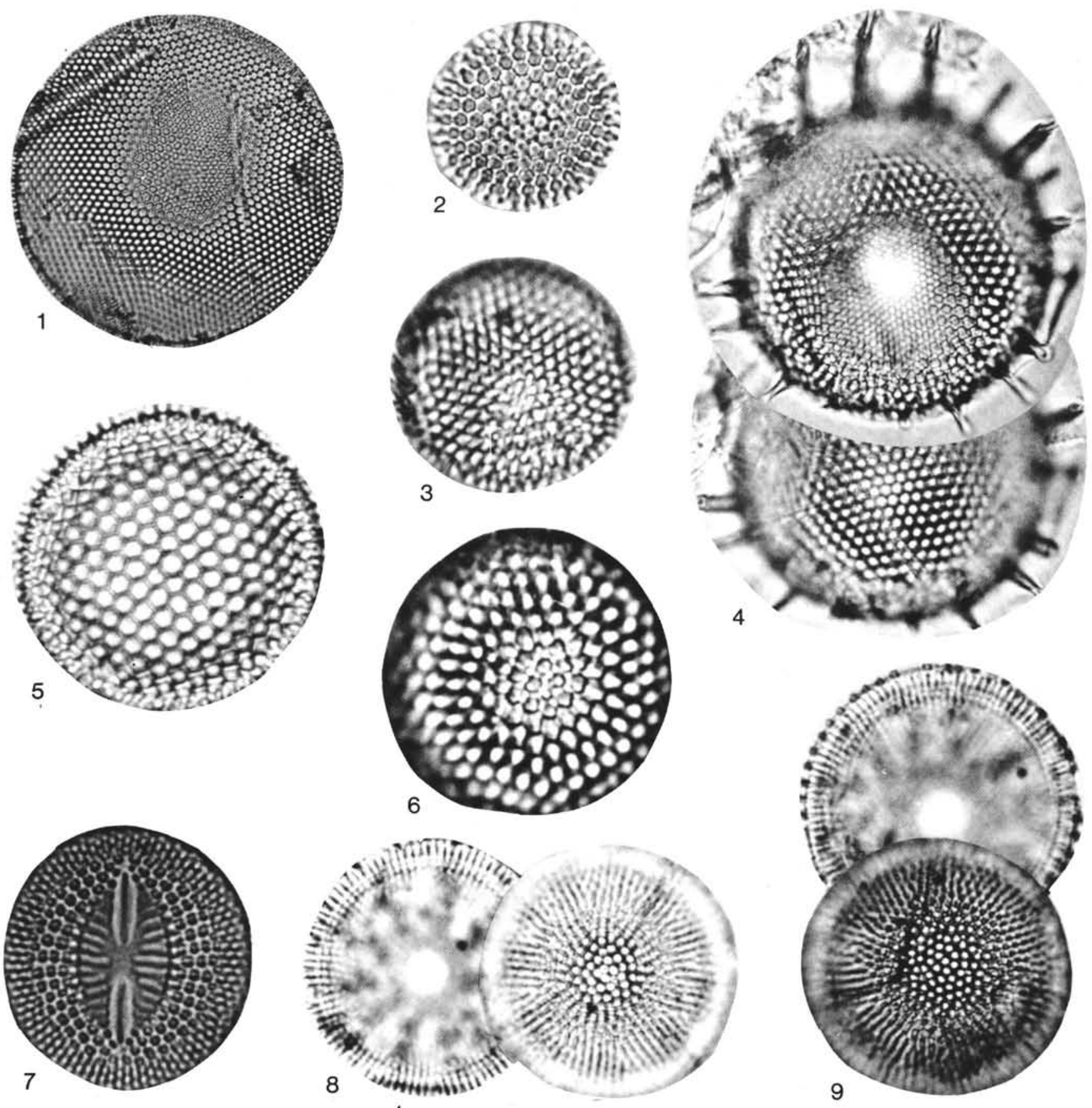

9

Plate 5. 1. Thalassiosira eccentrica (Ehrenberg) Cleve, diameter $78 \mu \mathrm{m}$, Sample 572A-4-3, 66-67 cm. 2. Thalassiosira fraga Schrader, diameter $18 \mu \mathrm{m}$, Sample 575A-1-1, 50-51 cm. 3. Thalassiosira praeconvexa Burckle, diameter $15 \mu \mathrm{m}$, Sample 573-12, CC. 4. Thalassiosira spumellaroides Schrader, low and high focus, diameter $34 \mu \mathrm{m}$, Sample 574C-7-2, 43-45. 5. Thalassiosira leptopus (Grunow) Hasle and Fryxell, diameter $35 \mu \mathrm{m}$, Sample 574-18-2, 42-43 cm. 6. Thalassiosira miocenica Schrader, diameter $16 \mu \mathrm{m}$, Sample 77B-10-6, 30-32 cm. 7. Raphidodiscus marylandicus Christian, length $24 \mu \mathrm{m}$, Sample 575A-7-3, 43-44 cm. 8. Thalassiosira convexa var. aspinosa Schrader, low and high focus, diameter $34 \mu \mathrm{m}$, Sample 574-3-4, 129-130 cm. 9. Thalassiosira convexa var. convexa Mukhina, low and high focus, diameter $38 \mu \mathrm{m}$, Sample 574$3-4,129-130 \mathrm{~cm}$. 


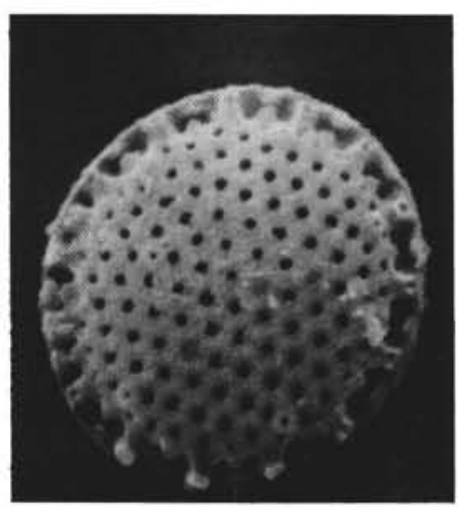

1
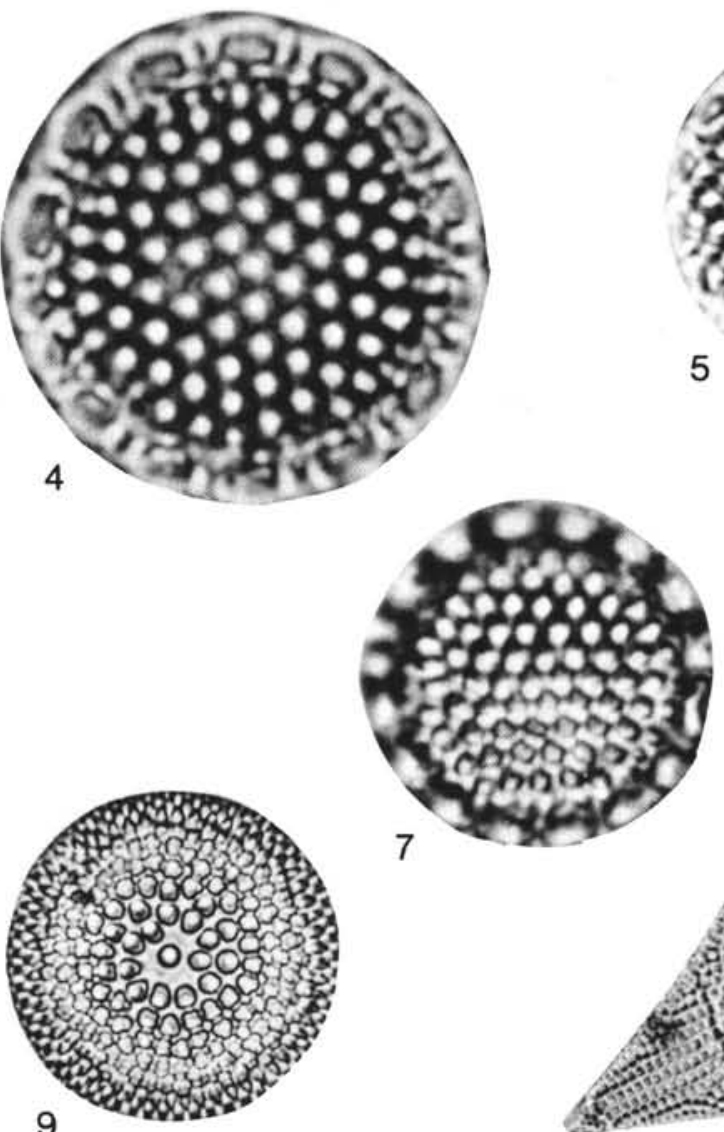

7

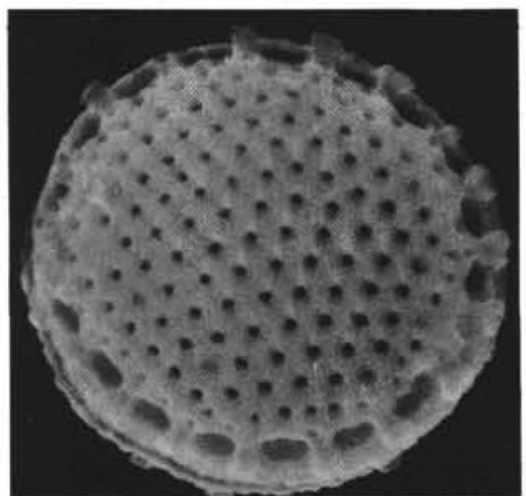

2

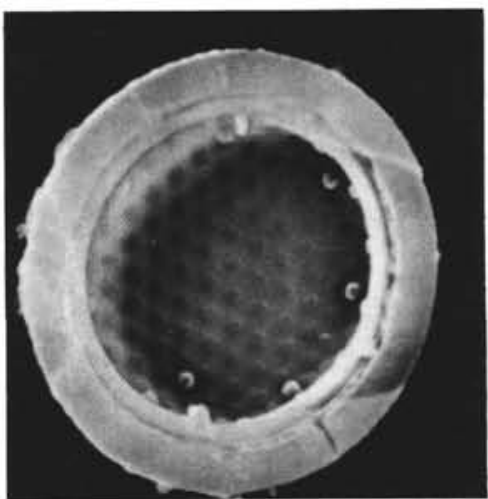

3
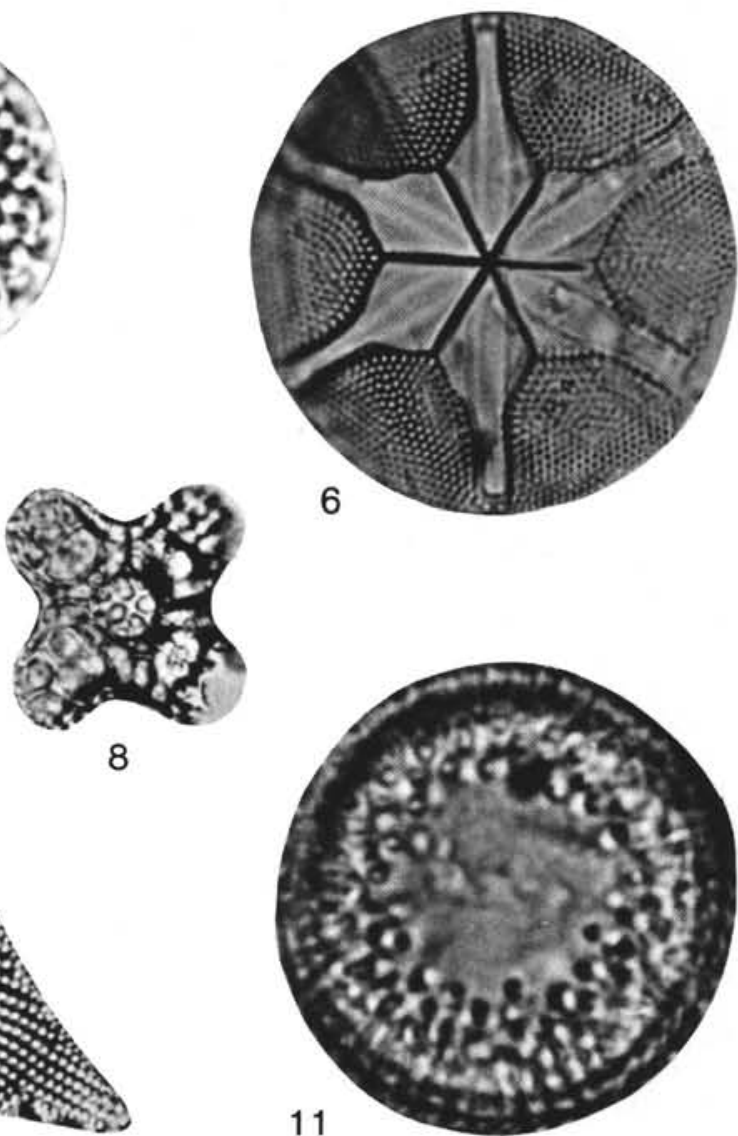

10

Plate 6. 1-3. Thalassiosira tappanae Barron, n. sp., scanning electron microscope pictures, Sample 574-19-2, 43-44 cm $(\mathrm{scale}$ bar $=3 \mu \mathrm{m})$, (1) USNM 370311, showing small accessory pore midway along radius at 3 o'clock position, (2) USNM 370312, (3) USNM 370313, internal view of valve showing marginal strutted processes and single labiate process at 7 o'clock position. 4, 5, 7. Thalassiosira tappanae Barron, n. sp., (4) diameter $14 \mu \mathrm{m}$, Sample 572-20-2, 43-44 cm, (5) Isotype USNM 370310, diameter $13 \mu \mathrm{m}$, Sample 572D-28-2, 50-52 cm, (7) Holotype USNM 370309 , diameter $12.5 \mu \mathrm{m}$, Sample 572D-28-2, 50-52 cm. 6. Asterolampra acutiloba Frenguelli, diameter $48 \mu \mathrm{m}$, Sample 573-12,CC. 8. Lisitzinia ornata Jousé, side $27 \mu \mathrm{m}$, Sample $574 \mathrm{C}-17-2,43-45 \mathrm{~cm}$. 9. Actinocyclus ingens Rattray, diameter $35 \mu \mathrm{m}$, Sample 574-16-2, 42-43 cm. 10. Triceratium pileus Ehrenberg, side $71 \mu \mathrm{m}$, Sample 575A-7-2, 43-44 cm. 11. Melosira architecturalis Brun, diameter $18 \mu \mathrm{m}$, Sample $574 \mathrm{C}$ $22, \mathrm{CC}$. 

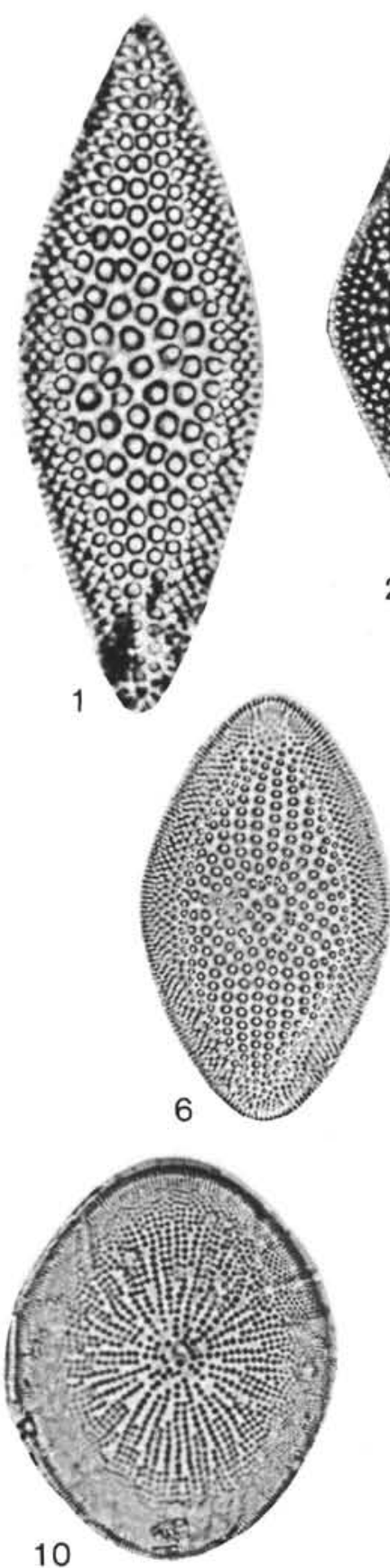
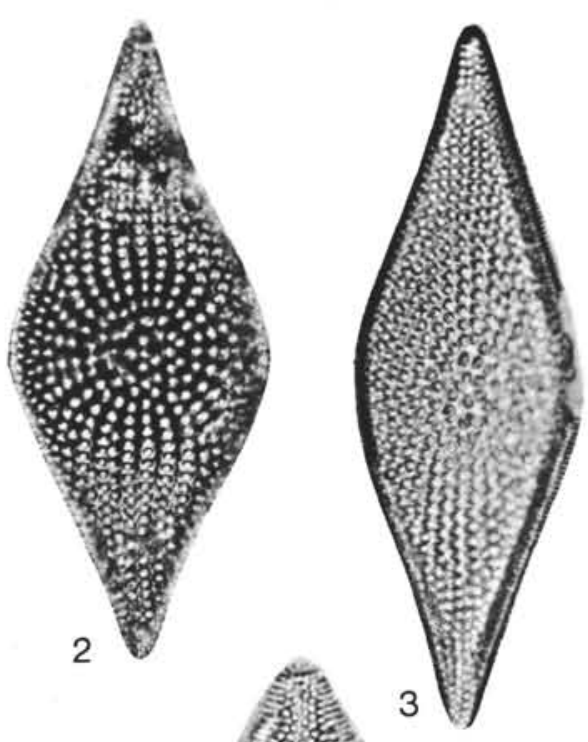
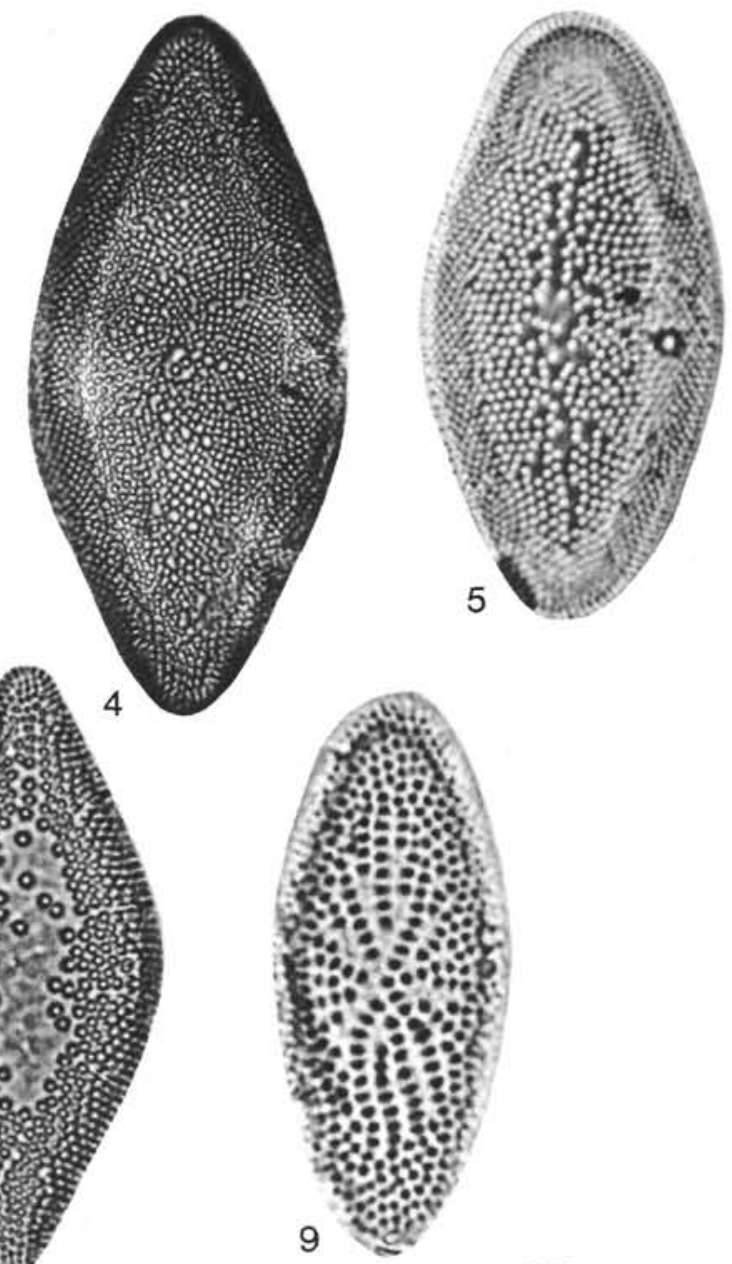

8
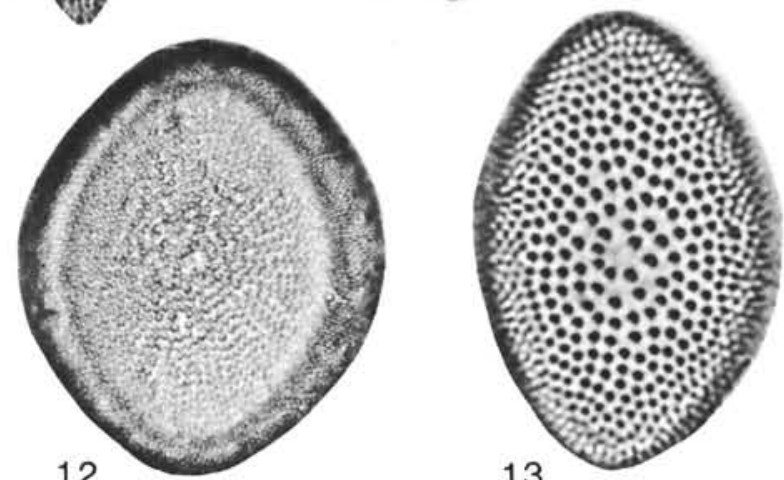

13

Plate 7. (All pseudonodules are at the 3 o'clock position.) 1. Coscinodiscus rhombicus Castracane, length $54 \mu \mathrm{m}$, Sample $574 \mathrm{C}-17, \mathrm{CC}$. 2-3. Coscinodiscus lewisianus var. rhomboides Barron, $\mathrm{n}$. var., (2) Holotype USNM 370299, length $114 \mu \mathrm{m}$, Sample 71-39-2, 87-89 cm, (3) USNM 370300 , length $116 \mu \mathrm{m}$, Sample 574C-20,CC. 4. Actinocyclus ellipticus f. lanceolata Kolbe, length $63 \mu \mathrm{m}$, Sample 77B-12-1, 62-66 cm. 5. Actinocyclus moronensis Deby, length $44 \mu \mathrm{m}$, Sample 574-11-4, 43-44 cm. 6. Coscinodiscus lewisianus var. similis Rattray, length $65 \mu \mathrm{m}$, Sample 575A-4-3, 42-43 cm. 7-8. Cestodiscus peplum Brun, (7) length $75 \mu \mathrm{m}$, Sample 575B-11-1, 106-107 cm, (8) length 59 $\mu \mathrm{m}$, Sample 574-22-2, 43$44 \mathrm{~cm}$. 9-10. Coscinodiscus lewisianus var. spiralis Barron, n. var., Sample 575-5-2, 43-44 cm, (9) USNM 370302, length $38 \mu \mathrm{m}$, (10) USNM 370303 , length $70 \mu \mathrm{m}$. 11. Coscinodiscus lewisianus var. robustus Barron, length $56 \mu \mathrm{m}$, Sample $575 \mathrm{~A}-6-3,42-43 \mathrm{~cm}$. 12. Actinocyclus ellipticus var. javanica Reinhold, length $79 \mu \mathrm{m}$, Sample 572D-11-1, 50-52 cm. 13. Actinocyclus sp. cf. A. ellipticus Grunow, early Miocene form, length $25 \mu \mathrm{m}$, Sample 575A-5-2, 42-43 cm. 

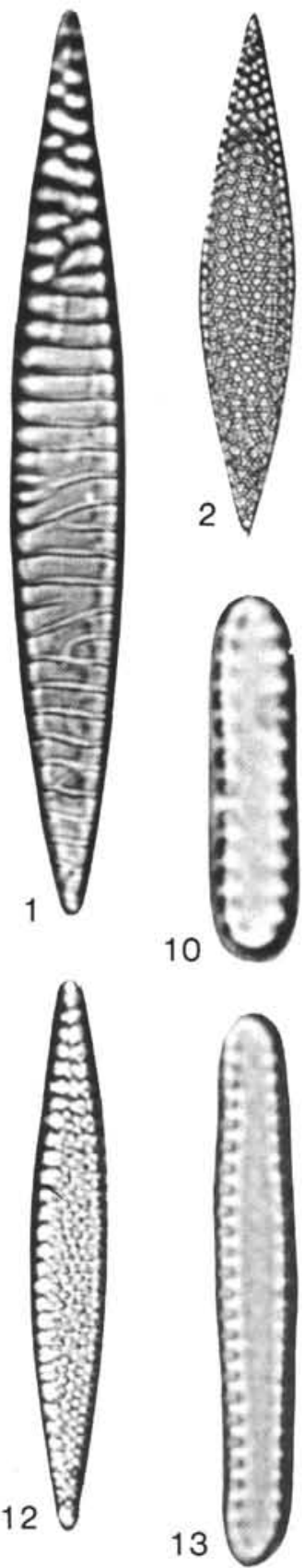
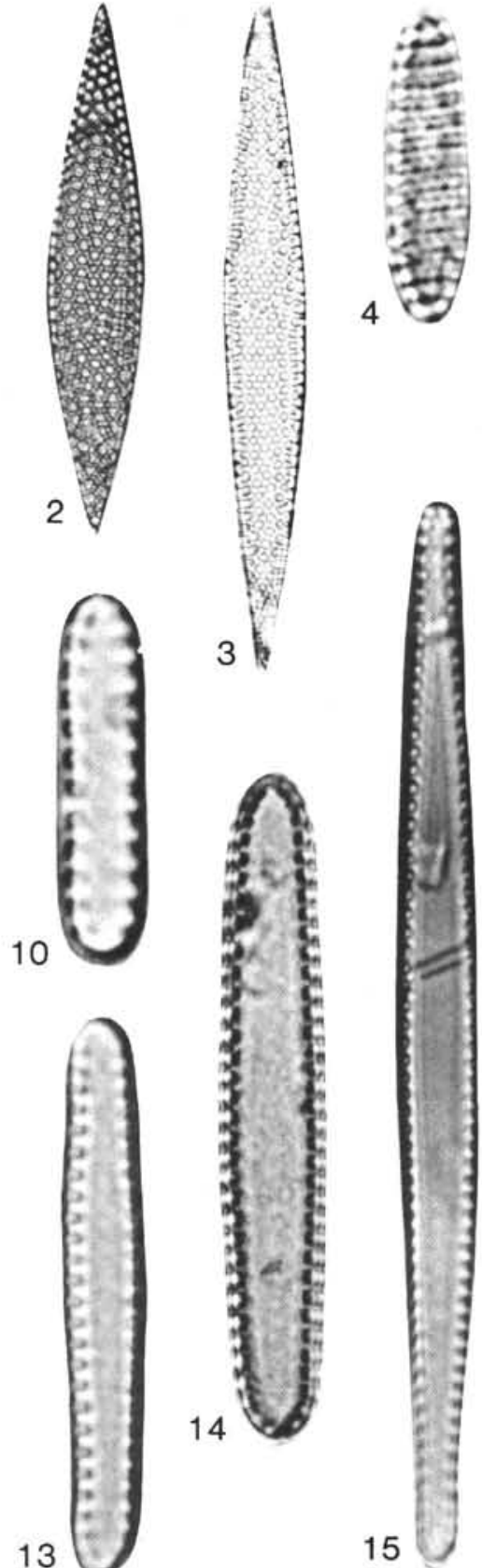

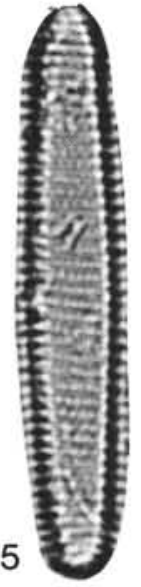

6
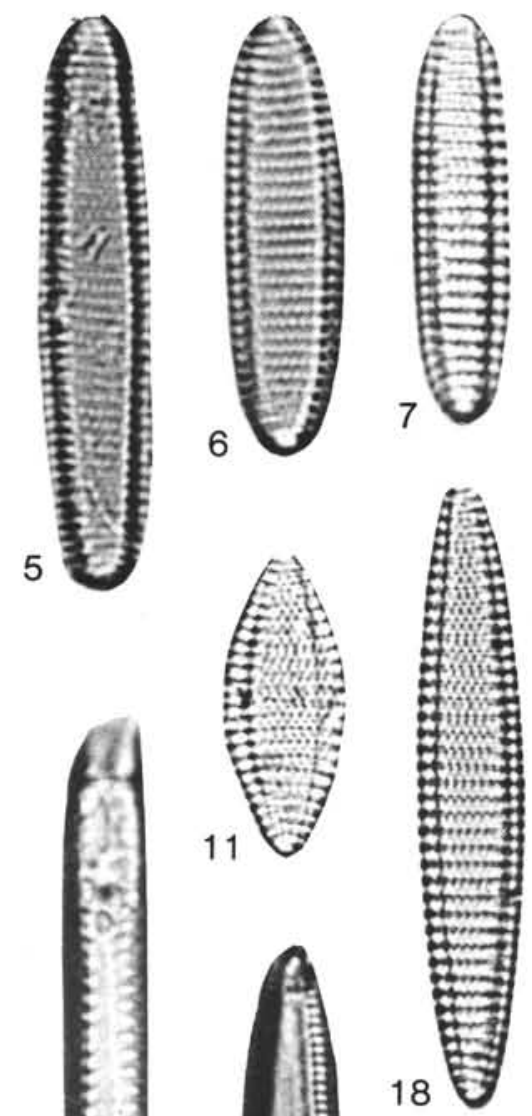

8
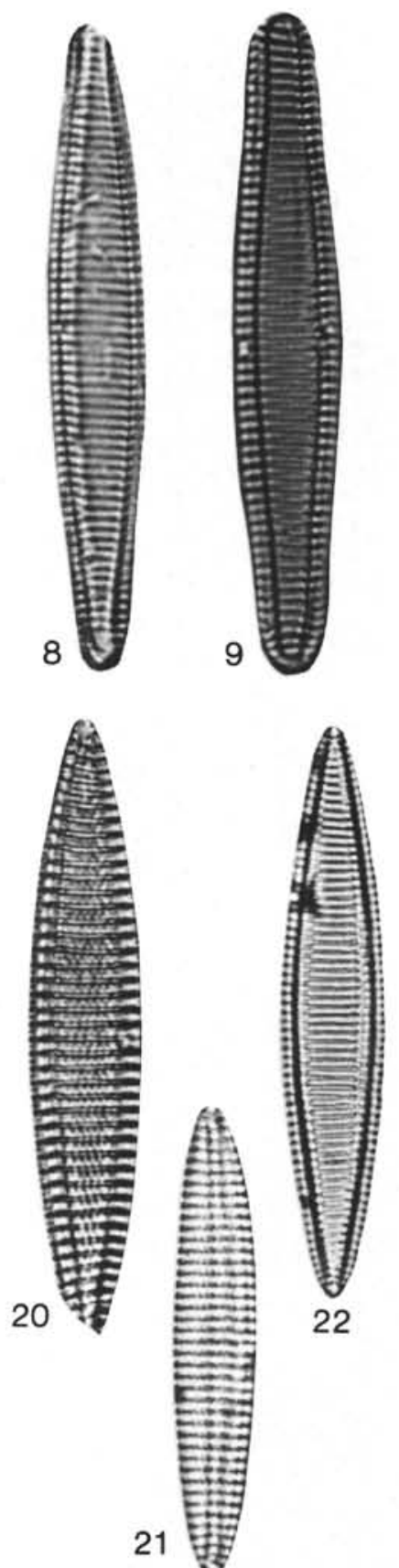

21

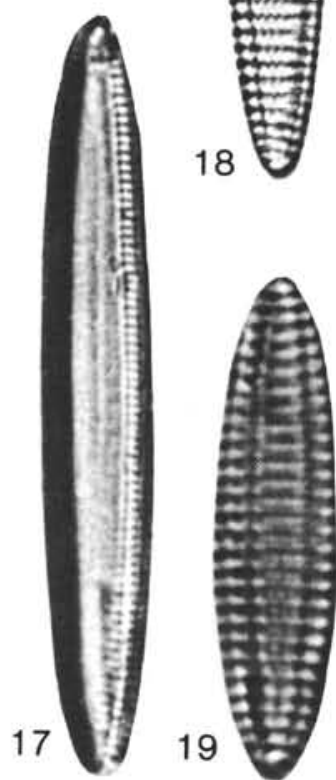

20

22

Plate 8. 1. Rossiella praepaleacea (Schrader) Gersonde, length $49 \mu \mathrm{m}$, Sample 572D-6,CC. 2. Rossiella paleacea (Grunow) Desikachary and Maheshwari, length $69 \mu \mathrm{m}$, Sample 77B-28-2, 28-30 cm. 3. Rossiella paleacea var. elongata (Barron) Barron, $\mathrm{n}$. comb., length $92 \mu \mathrm{m}$, Sample $574-$ 10-6, 43-45 cm. 4. Nitzschia porteri Frenguelli sensu Burckle (1972), length $14 \mu \mathrm{m}$, Sample 573D-11-1, 50-52 cm. 5-6. Nitzschia cyclindrica Burckle s. ampl., Sample 573-17-2, 62-63 cm, (5) length $34 \mu \mathrm{m}$, (6) length $28 \mu \mathrm{m}$. 7. Nitzschia cyclindrica Burckle s. str., length $28 \mu \mathrm{m}$, Sample 573-12,CC. 8-9. Nitzschia fossilis (Frenguelli) Kanaya and Koizumi, (8) length $48 \mu \mathrm{m}$, Sample 572D-10,CC, (9) length $42 \mu \mathrm{m}$, Sample 57313,CC. 10. Thalassionema nitzschioides var. parva Heiden and Kolbe, length $12 \mu \mathrm{m}$, Sample 574-12-4, 43-45 cm. 11, 18. Nitzschia jouseae Burckle, (11) length $27 \mu \mathrm{m}$, Sample 574-3-4, 129-130 cm, (18) elongated form, length $50 \mu \mathrm{m}$, Sample 572A-6-3, 66-67. 12. Bogorovia veniamini Jousé, length $57 \mu \mathrm{m}$, Sample 575A-22,CC. 13, 15. Thalassionema nitzschioides Grunow, (13) length 27 $\mu \mathrm{m}$, Sample 574-20-2, 43-44 $\mathrm{cm}$, (15) length $65 \mu \mathrm{m}$, Sample 572D-6-2, 50-52 cm. 14. Thalassionema robusta Schrader, length $41 \mu \mathrm{m}$, Sample 574-11-2, 43-45 $\mathrm{cm}$. 16. Thalassiothrix longissima Cleve and Grunow, width $5 \mu \mathrm{m}$, Sample 574-20-2, 43-44 cm. 17. Synedra jouseana Sheshukova-Poretzkaya, length $51 \mu \mathrm{m}$, Sample 574C-17,CC. 19. Nitzschia miocenica Burckle, length $22 \mu \mathrm{m}$, Sample 77B-12-6, 30-32 cm. 20. Nitzschia praereinholdii Schrader, length $57 \mu \mathrm{m}$, Sample 572D-10,CC. 21. Nitzschia miocenica var. elongata Burckle, length $42 \mu \mathrm{m}$, Sample 573-12,CC. 22. Nitzschia reinholdii Kanaya and Koizumi, length $56 \mu \mathrm{m}$, Sample 572A-6-3, 66-67 cm. 

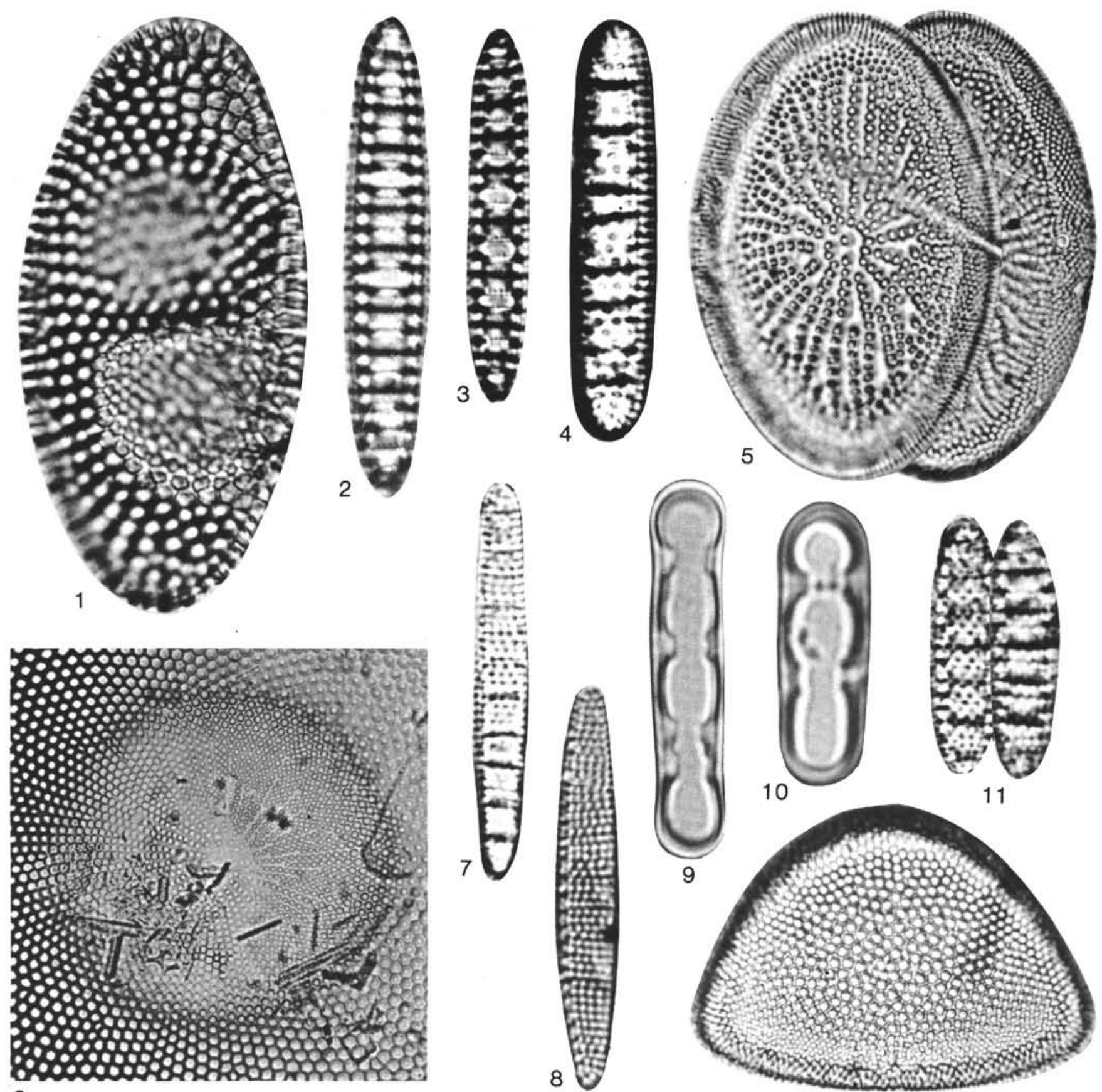

6

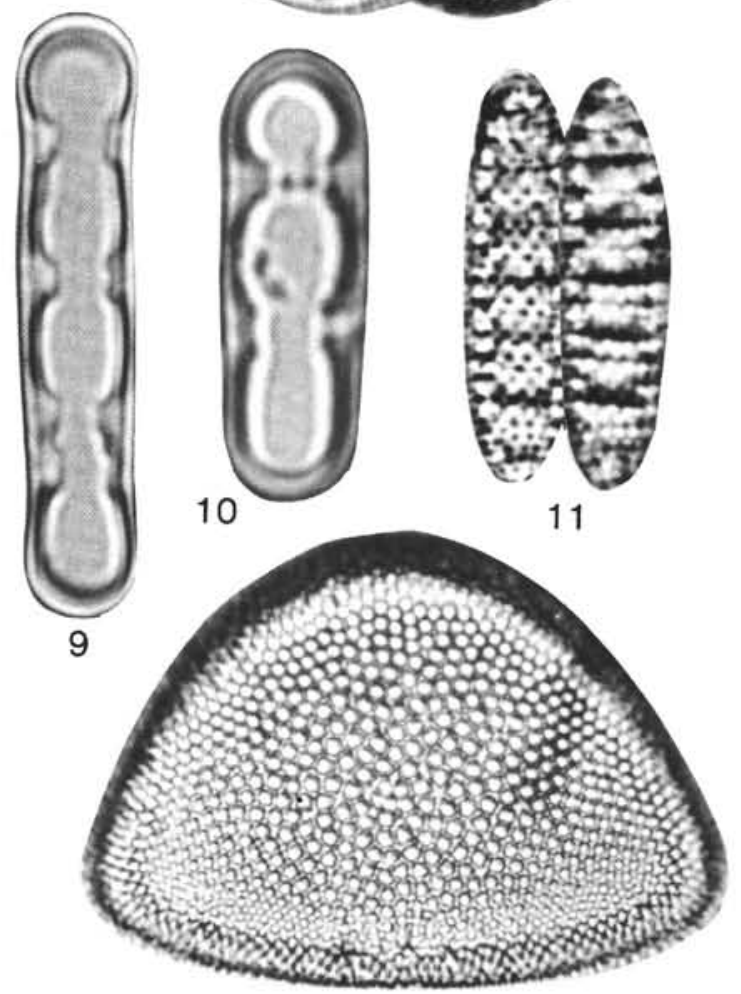

12

Plate 9. 1. Coscinodiscus yabei var. ellipticus Barron, n. sp., Isotype USNM 370308, length $46 \mu \mathrm{m}$, Sample 572D-10-4, 50-52 cm. 2-3. Denticulopsis hustedtii (Simonsen and Kanaya) Simonsen, (2) length $44 \mu \mathrm{m}$, Sample 572D-19-3, 50-52 cm, (3) length 35 $\mu \mathrm{m}$, Sample 574-10-6, 43-45 cm. 4. Denticulopsis sp. cf. D. kanayae (Akiba) Barron, length $36 \mu \mathrm{m}$, Sample $575 \mathrm{~A}-1-1,50-51 \mathrm{~cm}$. 5. Coscinodiscus lewisianus var. spiralis Barron, n. var., Holotype USNM 370301, high and low focus (note pseudonodule at 3 o'clock position), length $57 \mu \mathrm{m}$, Sample $575-5-4$, $43-44 \mathrm{~cm}$. 6. Coscinodiscus gigas var. diorama (Schmidt) Grunow, central area (scale bar $=20 \mu \mathrm{m}$ ), Sample 574-14,CC. 7. Denticulopsis nicobarica (Grunow) Simonsen, length $33 \mu \mathrm{m}$, Sample 575A-1,CC. 8. Nitzschia maleinterpretaria Schrader, length $35 \mu \mathrm{m}$, Sample 575A-6-1, 42$43 \mathrm{~cm}$. 9-10. Denticulopsis praedimorpha (Akiba) Akiba, Sample 574-12-4, 43-45 cm, (9) length $21 \mu \mathrm{m},(10)$ length $16 \mu \mathrm{m}$. 11. Denticulopsis punctata f. hustedtii (Schrader) Simonsen, low and high focus, length $25 \mu \mathrm{m}$. 12. Hemidiscus cuneiformis Wallich, length $46 \mu \mathrm{m}$, Sample $572 \mathrm{D}-$ $10, \mathrm{CC}$. 